SIMULATION AND OPTIMIZATION OF AN EXISTING ETHYLBENZENE DEHYDKOGEINATION REACTOR 


\section{SIMULATION AND OPTIMIZATION OF AN EXISTING ETHYLBENZENE DEHYDROGENATION REACTOR}

\section{By}

JOHN G. P. SHEEL, B. ENG.

A Thesis

Submitted to the Faculty of Graduate Studies in Partial Fulfilment of the Requirements for the degree of Master of Englneering

McMaster University

December 1966 
MASTER OF ENGINEERIIVG (1966)

(Chemical Engineering)
Mclaster University

Hamilton, Ontario.

TITLE: Simulation and Optimization of an Existing Ethylbenzene Dehydrogenation Reactor.

AUTHOR: John G. P. Sheel, B. Eng. (McGill University)

SUPERVISOR: Dr. C. M. Crowe

SCOPE AIND CONTENTS: The main purpose of this research was to find, from a simulation of an existing

reactor under rather heavy constraints, how upon removal of these limitations the same reactor could be operated more economically and efficiently. An accurate, simplified model of the process was developed and used in the design of single and double bed reactors with very consistent results. A better understanding of the process variables, reactions and constraints was obtained by extrapolation of the model within reasonable bounds.

The usefulness of a multivariable search technique applied to a relatively complicated process was proven. Such techniques as Pontryagin's Maximum Principle ${ }^{1}$ and dynamic programming ${ }^{2}$ become unwieldy for processes involving many state variables. An engineer can quickly grasp the ideas of multivariable search methods whereas it is difficult to understand the above more elaborate techniques without much study. This report may be particularly useful to plant-process engineers who seek a practical optimum-seeking method. 


\section{TABLP_OP CONTENTS}

1. ABSTRACT

2. PROCESS DESCRIPTION

2.1 A Typical Plant

2.2 Basic Principles

2.3 Polymer Plant Setup

3. MODEL DEVELOPMENT . 8

3.1 Simplifications and Assumptions 8

3.2 Basic Reactions 9

3.3 Reaction Rate Equations 13

3.4 Material Balances $\quad 17$

3.5 Energy Balance 18

3.6 Pressure Drop 19

3.7 Heats of Reaction 21

3.8 Heat Capacities 22

3.9 Calculations 24

4. DATE 25

4.1 Data Available. 25

4.2 Project Limitations 28

4.3 Treatnent of Data - Simplifications 28

5. TESTING OF' MODEL 31

5.1 Frequency Factor Searches 31

5.2 Runge-Kutta Step Size Studies 32

5.3 Poly-29 Cases 36

5.4 Effect of Varying $\Delta E_{1}$, The Activation Energy 37 
5.5 Parameter Studies

(1) Variation of Mixed Feed Temperature 40

(2) Variation of Steam Rate Only 40

(3) Variation of Steam Rate and Inlet Pressure as a Function of Molar Flow Rate

41

(4) Variation of Mixed Feed Temperature over Large Ranges

41

(5) Variation of Inlet Pressure Only 41

5.6 Reliability of Model

48

5.7 Discussion of Temperature Profiles 50

6. PRTPLFATION FOR OPTIMIZATION STUDIES 53

6.1 Choice of the Cost Function 53

6.2 Costs Not Included in the Cost Function 55

6.3 Regression Analysis Studies 58

6.4 Time studies 59

7. METHOD OF OPTIMIZETION 62

7.1 The General Method 62

7.2 Handling of Constraints 66

8. OPTIMIZATION AND DESIGN STUDIES 72

8.1 Design and Optinization of a Single Bed 72

8.1.1 Aims, Variables and Constraints 72

8.1.2 Reactor Situations Studied 73

8.1.3 Discussion of Results 77

8.1.4 Conclusions 81

8.2 Design and Optinization of a Double Bed 83

8.2.1 Ains, Variables and Constraints 83

8.2.2 Discussion of Reslits 84

8.2.3 Conclusions 86 
8.3 Application of Two-Bed System to Present Reactor

8.3.1 Proposed Changes Explained

8.3.2 Discussion of Results

9. OVERALI CONCLUSIONS

91

10. FUTURE WOFK

94

REFERENCES

96 


\section{FIGURE INDEX}

1. OVERALL PROCESS 3

2. THE REACTOR SYSTIM AND APRIL CASE FLOWS

3. REACTOR CLOSE UP 27

4. $X_{1}$ VERSUS $Z$ FOR APRII MODEL RESULTS . 33

5. VARTation OF $\Delta \mathrm{E}_{1}$, COMPEISSATION AITH CHANGE IN $\mathrm{A}_{1} 38$

6. VARIATION OF MIXED FEDD TEMPERATURE - APRIL CASE 42

7. VARIATION OF STEAM RATE ONLY 43

8. VARIATION OF STEAM RATE AND IIELET PRESSURE AS A
FUNCTION OF TIOLAR FLOW RATE

9. X VERSUS $Z$ - MAIN REACTION - VARIOUS M.F.T. 45

10. X VERSUS Z - SIDE REACTIONS - VARIOUS M.F.T. 46

11. VARIATION OF INLET PRESSURE ONLY 47

12. COMPARISON OF CALCUIATED TE:PPERATURE BROFILE NITH

13. COMPLISON OF REGRESSION EOUATION FOR GAIN WITH MODEL 56

14. MAP OF GAIN RESPONSE FOR REGRESSION EOUATION

15. ILLUSTRATION ROSENBROCK SEARCH 65

16. CONSTREIITS - HIGH FAILURES FOR $\mathrm{X} \leq \mathrm{M}$

17. CONSTRAIHTS - MIRẼOR IMAGE FOR XI + X2 $\leq M \quad 70$

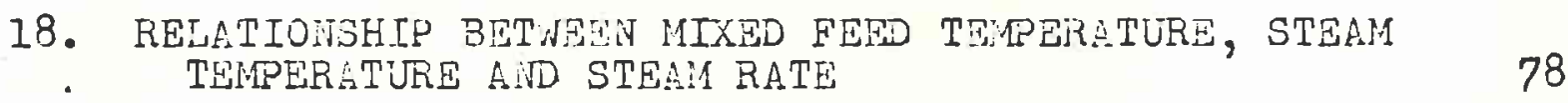

19. RESPONSE ( $\$$ HR.) AS A FUNCTION OF STEM TEMPERATUEE
AID FLON RATE. (SINGL BED)

20. 3 VARIABIE RESPONSE AS A FUNCTION OF STEAM TETPERATURE AND F'LON RA'TE AT FIXED BED DEPTHS

21. CORPARISON OF SIIGGE AND DOUBLE BED GONVERSION AND TEMPERATURE PROTISES 


\section{TABLE INDEX}

1. PLANT DATA AVAIIABLE

(A) Process Variables

(B) Hydrocarbon Feed Breakdown

(C) Liquid Product Breakdown

12

(D) Gas Analysis

12

12

2. TEMPERATURE PROFILE DATA

3. MODEL RESULTS

(A) Product Distributions

(B) Typical Gas Analysis Comparison

15

(C) Conversions of Reactions

(D) Temperature, Pressures

4. SAMPLE RUNGE-KUTTA STEP SIZE SURVEY

5. VALUE OF CHEMicals

54

6. OPTIMIZATION OF REGRESSION EQUATION

7. TEMPRRATURE OUTSIDE VTRSUS TEMPERATURE INSIDE THE INTEGRATION 


\section{APPENDICES}

1. CHOICE OF EQUILIBRIUM CONSTANT $\left(K_{p}\right)$ EXPRESSION FOR MAIIN REACTION

2. ACTIVATION ENERGIES 100

3. FREQUTHCY FACTORS 100

4. $\triangle H$, LINEAR VERSUS CUBIC FUICTION OF TEMPERATURE 102

5. SINGLE BED ETFYLBEIZENE DEHYDROGENATION MODEL 104

6. POLY-29 CASES RŨN JITH MEAN POLY-29 CASE FREZUENCY FHCTORS

7. MATERIAL BAIANCE - 2 BED SITUATION WITH STEAM ADDITIOIT BETWEEN BEDS

8. DEVELOPMENT OF COST FUITCTION

9. REGRESSION EQUATION

10. THE ROSENBROCK SEARCH PROGRAMME

11. OPTIMIZATION OF A 2-BED SITUATION

12. ROSEITBROCK SRARCHES

13. SELECTED CASES - COMPIETE OPTIMUM OPERATION CONDITIONS

14. ERROR IN $\mathrm{C}_{\mathrm{p}}$ OF BEITZENE 131

15. VALIDITY OF dP/dZ TREATMENT 132 


\section{ACKINO NLEOGMENTS}

The author would like to express his appreciation to Dr. C. M. Crowe of Mcilaster University and to the Polymer Corporation of Sarnia, Ontario for the assistance which they have given during the course of this project. 


\section{ABSTRACT}

A mathematical model has been put together in order to simulate the dehydrogenation of ethylbenzene to styrene in an ideal, adiabatic reactor. The model includes five associated side reactions along with the main one. The differential equations describing the process are integrated by the fourth order Runge-Kutta-Gill method ${ }^{3}$ on an IBM 7040 digital computer. Various parametric studies are presented.

A cost function ( $\$ G A I N E D / H O U R$ ) was chosen and for numerous combinations of process variables, subjected to actual. and fictitious sets of constraints, the single bed reactor was optimized. Knowledge and experience gained from these stuãies was applied to the design of a double bed reactor with steam addition at the entrance of each bed. Again, the two-bed situations were optimized. In all optimization studies, a multivariable search technique, that of Rosenbrock ${ }^{4}$, was used; slight modifications were necessary for handing constraints.

The problem of catalyst aglng has not been investigated since Insufficient data were available. All work carried out is for constant hydrocarbon feed rate and composition at a monent in the life of the catalyst.

All results are consistent and show that the single existing reactor can be operated more efficiently if the present plant constraints can be surmounted. The model can be used for the design of new reactors of a type similar to the existing one. 


\section{PROCESS DESCRIPTION}

\subsection{A Typical Plant}

The production of styrene from benzene and ethylene consists of three basic steps:

(1) ethylbenzene synthesis from benzene and ethylene

(2) ethylbenzene dehydrogenation

(3) styrene separation

Very simply, the overall process may be represented by the flow diagrain of Figure 1.

of the three steps, our only concern is the ethylbenzene dehydrozenation unit. It is assumed that the styrene finishing columns can cope with all exit compositions of the reactor and so, little improvenent can be made here. The alkylation section could perhaps be operated more efficiently but that too is not our concern, since little is known of the exact nature of the ethylbenzene synthesis ${ }^{5}$. There is more information about the reactions which take place in the dehydrogenation reactor ${ }^{6}$, although which of the numerous postulated ones (see section 4.2) really occur is open to question. We will forego all monetary gains made in reduction of recycle strean rates and will concentrate only on increasing the yield (\$GRINED/HOUR) of the reactor. Figure 2 shows the area of concern.

Our tool will be a mathenatical nodel whose parameters have been derived from a single case. This model will be used for extrapolating the process variables over reasonable ranges, 
FIGURF 1

OVERALI, PROCESS

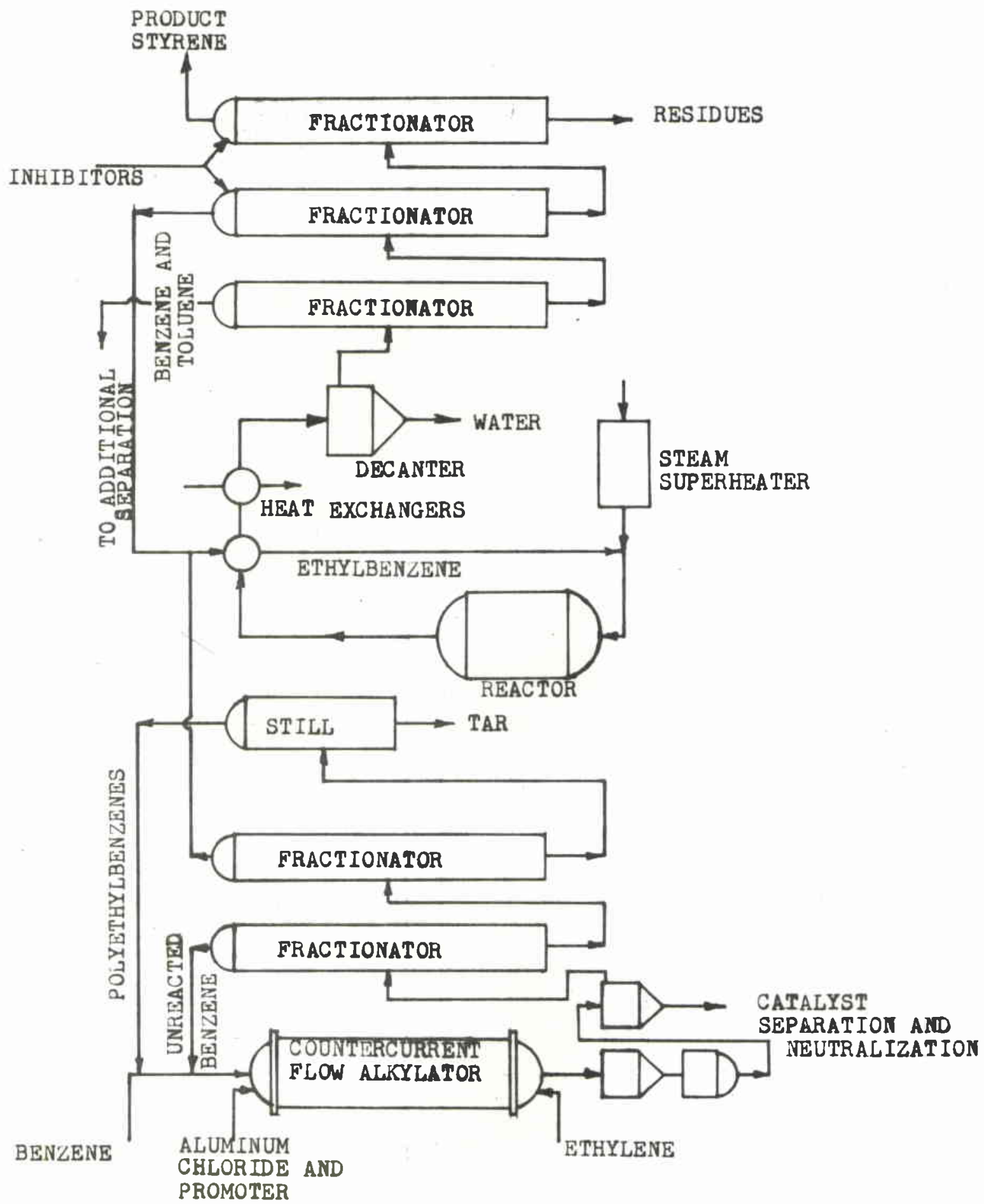




\section{ITQURE 2}

\section{THE REACTOR SYSTEM AND APRLL CASE FLOWS}

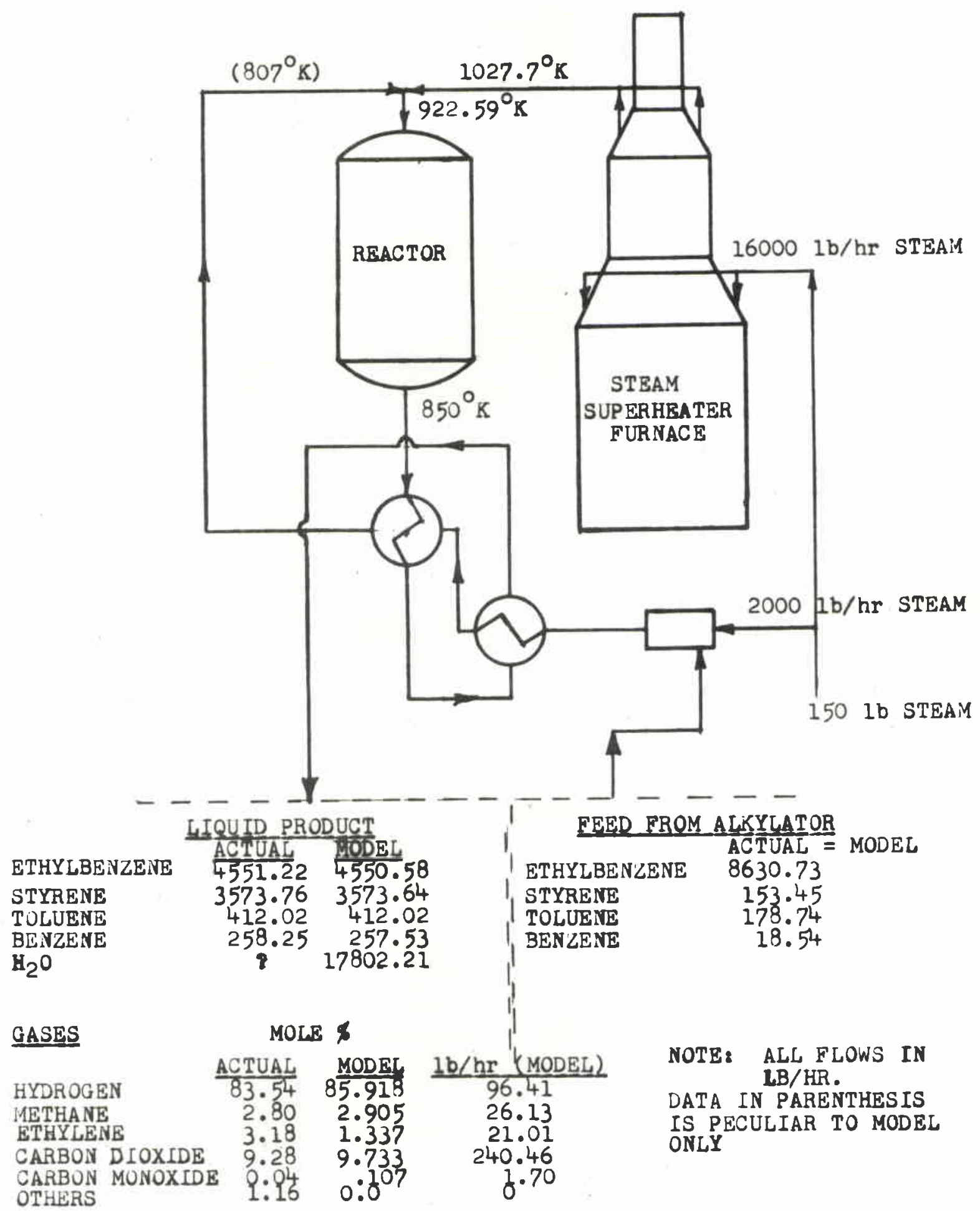


thus showing trends comparable to those found from pilot plant studies or extensive plant factorial design runs. Since our plant is operating at a capacity limited by constraints, an EVOP search 7 is impossible. A model seems to be the most practical of all possibilities available.

\subsection{Basic Principles}

The equilibrium constant, $\mathrm{K}_{\mathrm{p}}$, for the main endothermic reaction increases with temperature:

$$
K_{P}=f(T)=\frac{N_{S} \cdot N_{H 2} \cdot P}{N_{E B} \cdot N_{T}}
$$

$$
\text { where } \begin{array}{rlrl}
N_{\mathrm{S}}=\text { moles styrene } & \mathrm{T}=\text { temperature } \\
\mathrm{N}_{\mathrm{H} 2}=\text { moles hydrogen } & P=\text { total pressure } \\
\mathrm{N}_{\mathrm{T}}=\text { total moles }=\mathrm{N}_{\mathrm{EB}}+\mathrm{N}_{\mathrm{H} 2}+\mathrm{N}_{\mathrm{S}}+\mathrm{N}_{\mathrm{I}} \\
\mathrm{N}_{\mathrm{EB}}=\text { moles ethylbenzene } & \mathrm{N}_{\mathrm{I}}=\text { moles inert }
\end{array}
$$

High styrene yield is favoured by a low pressure or an increase in the relative amount of the inert compound $\left(N_{I}\right)$ which nay be either benzene or steam, the latter being more commonly used. Steam is normally added in the ratio of $2.61 \mathrm{~b} . / 1 \mathrm{~b}$. of hydrocarbon ${ }^{5}$ giving about 15 moles of steam per mole of ethylbenzene. The total pressure is about 1.4 atmospheres 5 while the reactor inlet temperature of the mixed feed varies around $600^{\circ} \mathrm{C} .-630^{\circ} \mathrm{C}$. With no steain at $630^{\circ} \mathrm{C}$, the equilibrium conversion is around $30 \%$; while with inert a conversion of $85 \%$ can be obtained 5 . The steam also provides the heat required to raise the hydrocarbons up to the required temperature. It 
also suppresses carbon formation. Direct heating leads to ethylbenzene decomposition.

In achieving a respectable conversion of the main reaction, by-product formation (i.e. benzene, toluene) must be kept at a minimum. Were it not for by-products, it would be best to operate at a very high temperature since the equilibriun conversion and the reaction rate of the main reaction are then highest. Unfortunately, the by-products' rate of formation increases very quickly with temperature and so, a convenient operating temperature represents a conpromise between the nain reaction and by-product reactions systens. A selective dehydrogenation catalyst is used so that more rapid formation of styrene is possible at lower temperatures with a minimum of side reactions.

\subsection{Polymer Plan:_Setup}

At Polyme: Corporation in Sarnia, Ontario, the reactor is now being operated at a sub-optimal nass velocity because of limitations in

(i) pressure drop

(ii) fur zace capacity

and (iii) condenser capacity.

This combination of constraints has forced operation at a hydrocarbon flow of $9000 \mathrm{Ib} / \mathrm{hr}$. with a total stean flow not exceeding $18000 \mathrm{lb} . / \mathrm{hr}$. at $1050^{\circ} \mathrm{K}$. The furnace can give more steam at a lower temperature but the product condenser system cannot handle the increased throughput. The actual stean to 
hydrocarbon ratio is $2.0 \mathrm{lb} . / \mathrm{lb}$. while $2.6 \mathrm{lb}$. per $1 \mathrm{~b}$. is desirable. The reactor inlet pressure is about 2.3 atmospheres (absolute); 1.4 atrospheres ${ }^{5}$ is norinal but unattainable. It appears that these constraints impose severe restrictions on the operation of the plant. Extrapolation of the operating variables with the model to values beyond these constraints should show conslderable overall improvement. 


\section{MODEL DEVESOP:AENT}

\subsection{Simplifications and_Ass}

Numerous assumptions pertaining to the ideality of the reactor or to the simplification of calculations were made. These are listed below.

(1) Plug flow was assurned.

(2) The reactor was thought to be operating close to adiabatic conditions and hence this assumption was used throughout. Variables such as the overall heat transfer coefficient and the ambient temperature have been eliminated, thus recucing the variables considered in optimization studies to those relevant only to the process.

(3) The pressure and tenperature rates of change with bed depth have been updated outside the integration in order to reduce the number of calculations required by each pass through the nodel. Only the material balances have been integrated according to the fourth order Runge-Kutta-Gill method. Each increnent has a constant pressure and temperature over it. The temperature has also been included inside the integration and a comparison is offered in section 6.4. The model does not suffer from these simplifications.

(4) Since this study deals with an optimization technique that requires numerous passes through the nodel, it was necessary to keep the calculation time per pass as low as possible. Certain suspected possible side reactions, which 
would have improved the accuracy of the model, were therefore oritted (Section 3.2). The six reactions chosen appear to be adequate and any improvement by addition of further reactions would only be offset by the extra time required for computation.

(5) The catalyst efficiency, although in reality varying with both tine and bed depth, has been considered to be constant. The nature of the data available (Section 4 ) has necessitated this assumption. Efficiency factors are tied up in the frequency factors, making it impossible to obtain absolute values.

(6) It was assured that none of the aromatic rings would deconpose. A discussion of this is found in section 4.3 . This assumption enabled the calculation of an overall material balance between the feed and liquid product-gas product streams.

(7) The choice of activation energies for the reactions may be open to question since sone of the values apply to different catalysts and reacting systems. Sections 3.3 and 5.4 elaborate on these activation energies.

other assumptions are relevant to particular cases only and these will be discussed as they arise in following sections of the report.

\subsection{Basic Reactions}

Research (References 5, 6, 13) shows that the following reactions could accur simultaneously in the reactor:
(1) $\mathrm{EB}$
$\rightarrow \mathrm{STY}+\mathrm{H}_{2}$
(2) $\mathrm{EB}$
$\rightarrow \mathrm{BZ}+\mathrm{C}_{2} \mathrm{H}_{4}$ 

(3) $\mathrm{EB}+\mathrm{H}_{2}$
$\rightarrow \mathrm{TOL}+\mathrm{CH}_{4}$
(4) $\mathrm{EB}+\mathrm{H}_{2}$
$\rightarrow \mathrm{BZ}+\mathrm{C}_{2} \mathrm{H}_{6}$
(5) $\mathrm{TOL}+\mathrm{H}_{2}$
$\rightarrow \mathrm{BZ}+\mathrm{CH}_{4}$
(6) $\mathrm{STY}+\mathrm{H}_{2}$
$\rightarrow \mathrm{BZ}+\mathrm{C}_{2} \mathrm{H}_{4}$
(7) STY,
$\rightarrow \mathrm{BZ}+\mathrm{C}_{2} \mathrm{H}_{2}$
(8) STY
$\rightarrow \mathrm{C}_{6} \mathrm{H}_{5} \mathrm{C}_{2} \mathrm{H}+\mathrm{H}_{2}$
(9) $\mathrm{C}_{6} \mathrm{H}_{5} \mathrm{C}_{2} \mathrm{H}+\mathrm{H}_{2} \mathrm{O} . \rightarrow \mathrm{C}_{6} \mathrm{H}_{5} \mathrm{CO}\left(\mathrm{CH}_{3}\right)$
(10) $\mathrm{C}_{2} \mathrm{H}_{6}$
$\rightarrow \mathrm{C}_{2} \mathrm{H}_{4}+\mathrm{H}_{2}$
(11) $\mathrm{C}_{2} \mathrm{H}_{4}$
$\rightarrow \mathrm{C}_{2} \mathrm{H}_{2}+\mathrm{H}_{2}$
(12) $\mathrm{C}_{2} \mathrm{H}_{2}$
$\longrightarrow \mathrm{H}_{2}+2 \mathrm{C}$
(13) $\mathrm{C}+2 \mathrm{H}_{2} \mathrm{O}$
$\rightarrow \mathrm{CO}_{2}+2 \mathrm{H}_{2}$
(14) $\frac{1}{2} \mathrm{C}_{2} \mathrm{H}_{4}+\mathrm{H}_{2} \mathrm{O}$
$\rightarrow \mathrm{CO}+2 \mathrm{H}_{2}$
(15) $\mathrm{CH}_{4}+\mathrm{H}_{2} \mathrm{O}$
$\rightarrow \mathrm{CO}+3 \mathrm{H}_{2}$
(16) $\mathrm{CO}+\mathrm{H}_{2} \mathrm{O}$
$\rightarrow \mathrm{CO}_{2}+\mathrm{H}_{2}$

LEGEND

$$
\begin{aligned}
& \mathrm{EB}=\text { ethylbenzene } \\
& \mathrm{STY}=\text { styrene } \\
& \mathrm{TOL}=\text { toluene } \\
& \mathrm{BZ}=\text { benzene }
\end{aligned}
$$

Apart from the main reaction (1) and two main side reactions $(2,3)$ very little is known about the lesser side reactions ( 4 to 16 ). It is generally accepted ${ }^{6}$ that reactions 1-3 constitute the most important ones. Any of the reactions 4 through 16 may be combined with the basic three. 
The plant feed, liquid product and gas product analyses (Table 1) showed that almost all of the liquid product could be described by ethylbenzene, styrene, benzene and toluene while most of the product gas could be attributed to hydrogen (83 mole \%) and carbon dioxide (10 mole \%). If these six compounds can be accounted for, the nodel would be representative of the plant situation. Methane and ethylbene would also be traced.

Which set of reactions of the sixteen presented will be most representative? since no acetylene was detected in the products, reactions involving this component (7, 11, 12) have been excluded from consideration. Also the carbon deposition and renoval reactions (12, 13) are neglected since we are concerned with the reactor at a given catalyst age. That is, the amount of carbon in the system will be constant. The acetophenone reactions $(8,9)$ have also been excluded since this compound was not detected in the hydrocarbon liquid and gas products. It could be that due to a relatively high solubility, this compound has dissolved in the water (coniensed steam) and so has escaped the analysis which were carried out.

It is inportant that the nodel not only be representative but that it involve as few of the above equations as possible in order to keep computation tine to a ninimum.

Preliminary models based on three $(1,2,3)$, four $(1,2,3,4)$ and $\operatorname{six}(1,2,3,14,15,16)$ reactions were found to be inadequate for representation of the gas product although 
TABLE_I

DATA AVAILABLE

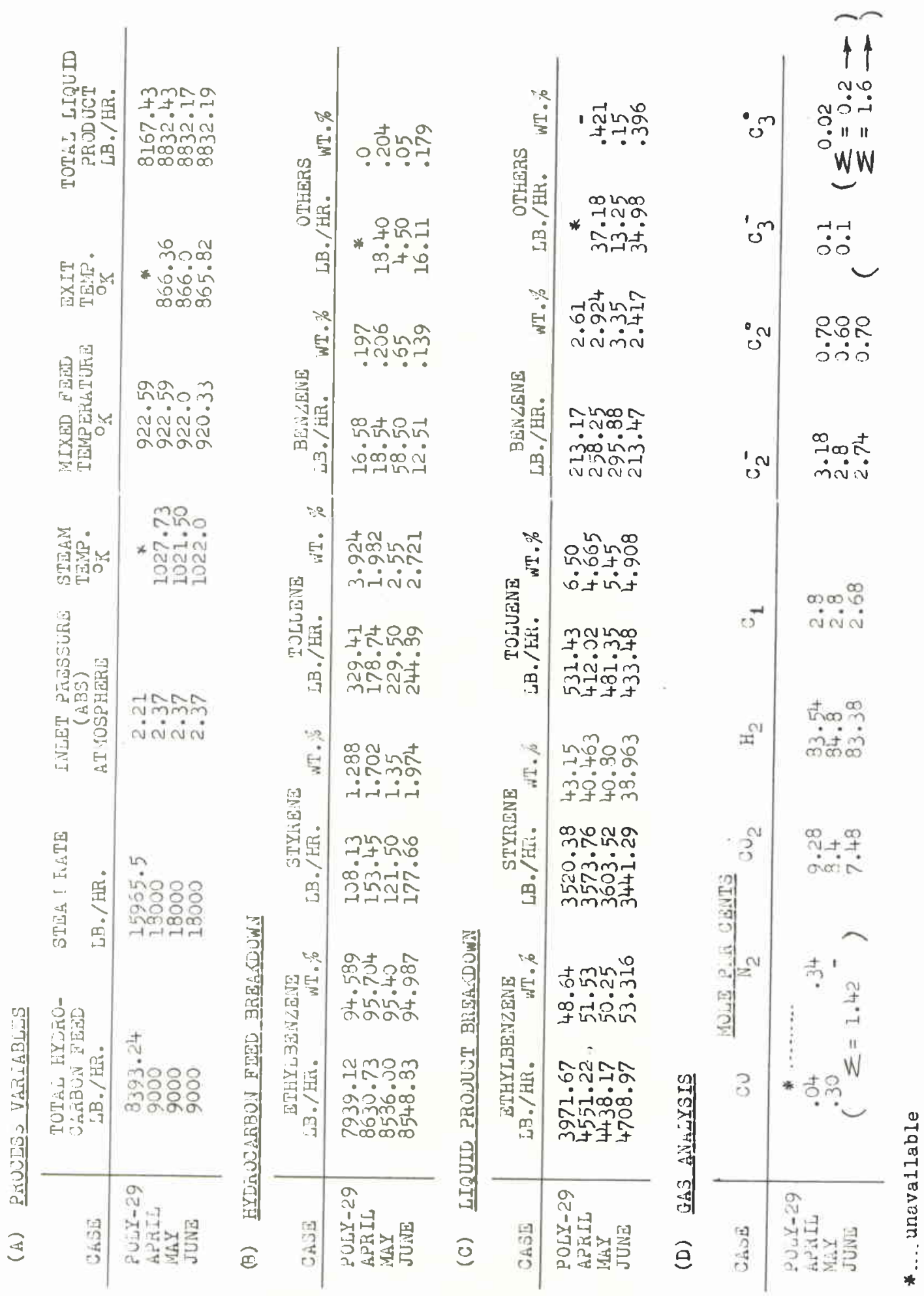


they could readily be nade to account for the liquid product by a suitable choice of the rate equation frequency factors, explained in Section 3.3.

It was found that a combination of reactions $1,2,3$, 14, 15 and 16 gave good results (Table 3) for both liquid and gas effluent streans. A further addition of reactions to these six would perhaps result in better answers, but at the expense of valuable coaputer time. Thus the chosen six reactions should suffice.

\subsection{Reaction Rite Equations}

The genersi rate expression used in the model has the form:

$$
\begin{aligned}
r_{i} & =k_{i} f\left(P_{i}\right) \\
\text { where } r & =1 b \cdot m o l e / s e c \cdot 1 b \text {. catalyst) } \\
k_{i} & \left.=1 b \cdot m o l e / s e c .1 b \text {. catalyst atmos. }{ }^{n}\right) \\
& =\operatorname{EXP}\left(-\Delta E_{i} / R T+A_{i}\right) \\
\Delta E_{i} & =\text { Activation energy in calories/gm.mole } \\
A_{i} & =\text { frequency factor exponent } \\
R & =1.987 \text { calories/gm.mole }{ }_{K} \\
T & ={ }_{K} \\
K_{p} & =\text { equilibrium constant (reaction } 1 \text { below) } \\
P_{T} & =\text { total pressure in atmospheres }
\end{aligned}
$$

* Appendix 1

* Appendix 2 and 3 


\section{TABLE 3}

\section{MODEL RESULTS}

(A) RRODUCT DISTRIBUTIONS (LB./HR.)

\begin{tabular}{l|rrrr} 
& \multicolumn{4}{|c}{ CASE } \\
COMPONENT & POLY-29 & APRIL & MAY & \multicolumn{1}{c}{ JUNE } \\
\hline Ethylbenzene & 3975.12 & 4550.58 & 4436.00 & 4713.31 \\
Styrene & 3517.13 & 3573.64 & 3600.45 & 3446.27 \\
Hydrogen & 89.35 & 96.41 & 95.02 & 95.42 \\
Ethylene & 18.52 & 21.01 & 24.88 & 10.25 \\
Benzene & 209.51 & 257.53 & 291.52 & 215.63 \\
Toluene & 526.13 & 412.02 & 478.45 & 442.29 \\
Methane & 22.91 & 26.13 & 28.02 & 15.73 \\
Ethane & 0.0 & 0.0 & 0.0 & 0.0 \\
Acetylene & 0.0 & 0.0 & 0.0 & 0.0 \\
Ethynylbenzene & 0.0 & 0.0 & 0.0 & 0.0 \\
Steam & 15810.66 & 17802.21 & 17815.84 & 17798.39 \\
Carbon Monoxide & 1.43 & 1.70 & 1.83 & 1.79 \\
Carbon Dioxide & 188.16 & 240.46 & 223.69 & 245.06 \\
Carbon & 0.0 & 0.0 & 0.0 & 0.0 \\
& & & &
\end{tabular}


TABLE 3 - Continued

(B) TYPICAL GAS ANALYSIS - COMPARISON BETWEEN PLANT AND MODEL FOR APRIT CASE

\begin{tabular}{|c|c|c|c|c|}
\hline \multirow[b]{2}{*}{ COIPOUND } & \multicolumn{2}{|c|}{ MODEL } & \multirow[b]{2}{*}{ MOL. $\%$} & \multirow{2}{*}{$\frac{\text { PIANT }}{\text { MOL. } \%}$} \\
\hline & LB. / HR . & LB.MOL./HR & & \\
\hline $\mathrm{H}_{2}$ & 96.41 & 48.20 & 85.918 & 83.54 \\
\hline $\mathrm{C}_{2} \mathrm{H}_{4}$ & 21.01 & .75 & 1.337 & 3.18 \\
\hline $\mathrm{CH}_{4}$ & 26.13 & 1.63 & 2.905 & 2.80 \\
\hline CO & 1.70 & .06 & 0.107 & 0.04 \\
\hline $\mathrm{CO}_{2}$ & 240.46 & 5.46 & 9.733 & 9.28 \\
\hline \multirow[t]{2}{*}{ OTFIERS } & 0 & 0 & 0 & 1.16 \\
\hline & & & $\Sigma=100.00$ & $\Sigma=100.00$ \\
\hline
\end{tabular}

(c) CONVERSIONS OF REACTIONS $\left(X_{F}\right)$

\begin{tabular}{|c|c|c|c|c|}
\hline $\begin{array}{l}\text { REACTION } \\
\text { NULBER }\end{array}$ & POLY-29 & $\begin{array}{l}\text { CASE } \\
\text { APRIL }\end{array}$ & MAY & JUNE \\
\hline 1 & $.43772 \mathrm{E} 00$ & .40397 E 00 & $.41305 \mathrm{E} 00$ & .38976 E 00 \\
\hline 2 & $.33028 \mathrm{E}-01$ & .37634 E-O1 & .36885 E-OI & $.32292 \mathrm{E}-01$ \\
\hline 3 & .28551 E-O1 & $.31145 \quad E-01$ & $.33411 \quad \mathrm{E}-01$ & .26607 E-01 \\
\hline 14 & $.40808 \mathrm{E}-02$ & $.46211 \mathrm{E}-02$ & $.41925 \mathrm{E}-02$ & .44701 E-02 \\
\hline 15 & $.79711 \mathrm{E}-03$ & .90337 E-03 & $.95565 \mathrm{E}-03$ & .11622 E-02 \\
\hline 16 & $.48202 \quad E-02$ & .54637 E-02 & .50828 E-02 & .55683 E-02 \\
\hline
\end{tabular}




\section{TABLE 3 - Continued}

(D) TEMPERATURES, PRESSURES

\begin{tabular}{c|rrrr} 
DATA & \multicolumn{4}{|c}{ CASE } \\
\hline Inlet Temperature $\left({ }^{\circ} \mathrm{K}\right)$ & 922.59 & 922.59 & 922.00 & 920.33 \\
Outlet Temperature $\left({ }^{\circ}\right)$ & 845.53 & 850.76 & 849.58 & 850.98 \\
Inlet Pressure (Atmos.) & 2.21 & 2.37 & 2.37 & 2.37 \\
Outlet Pressure (Atmos.) & 2.13 & 2.29 & 2.29 & 2.29
\end{tabular}




\begin{tabular}{|c|c|c|}
\hline $\begin{array}{l}\text { REICTION } \\
\text { FUMBRR }\end{array}$ & REACTION & EQUATION \\
\hline 1 & $\mathrm{~EB} \longrightarrow \mathrm{STY}+\mathrm{H}_{2}$ & $r_{1}=k_{I} \cdot\left(P_{E B}-\frac{P_{S T Y}}{K_{p}} \cdot P_{H_{2}}\right)$ \\
\hline 2 & $\mathrm{~EB} \rightarrow \mathrm{BZ}+\mathrm{C}_{2} \mathrm{H}_{4}$ & $r_{2}=k_{2} \cdot P_{E B}$ \\
\hline 3 & $\mathrm{~EB}+\mathrm{H}_{2} \longrightarrow \mathrm{TOI}+\mathrm{CH}_{4}$ & $r_{3}=k_{3} \cdot P_{E B} \cdot P_{H_{2}}$ \\
\hline 14 & $\mathrm{H}_{2} \mathrm{O}+\frac{1}{2} \mathrm{C}_{2} \mathrm{H}_{4} \rightarrow \mathrm{CO}+2 \mathrm{H}_{2}$ & $r_{14}=k_{14} \cdot P_{\mathrm{H}_{2} \mathrm{O}} \cdot\left(\mathrm{P}_{\mathrm{C}_{2} \mathrm{H}_{4}}\right)^{\frac{1}{2}}$ \\
\hline 15 & $\mathrm{H}_{2} \mathrm{O}+\mathrm{CH}_{4} \rightarrow \mathrm{CO}+3 \mathrm{H}_{2}$ & $r_{15}=k_{15} \cdot P_{\mathrm{H}_{2} \mathrm{O}} \cdot P_{\mathrm{CH}_{4}}$ \\
\hline 16 & $\mathrm{H}_{2} \mathrm{O}+\mathrm{CO} \longrightarrow \mathrm{CO}_{2}+\mathrm{H}_{2}$. & $r_{16}=\frac{P_{T}}{T^{3}} \cdot k_{16} \cdot P_{\mathrm{H}_{2} O} \cdot P_{C O}$ \\
\hline
\end{tabular}

As shown, only the main reaction has been considered to act in reverse. The other five do not approach equilibrium in the extent of the lst and hence only their forward reaction rate is dealt with $(\sigma, i)$. Slight error is introduced here but it should be quite insignificant. All six reactions are assumed to occur on the catalyst surface.*

3.4 Material Balances

The material balance equations are now written according to the plug flow assumption. Conversions $\left(X_{i}\right)$ are expressed as the mole fraction of ethylbenzene (Reactions $1,2,3$ ) or steam (Reactions $14,15,16$ ) reacted. * References may be found in Appendix 2. 


\begin{tabular}{|c|c|}
\hline $\begin{array}{l}\text { REACT ION } \\
\text { NUMBER }\end{array}$ & MATERIAL BALAINCE \\
\hline 1 & $E \frac{d X_{1}}{d z}=r_{I} \cdot A \cdot \dot{\rho}_{B}$ \\
\hline 2 & $\mathrm{E} \frac{\mathrm{dX}_{2}}{\mathrm{dz}}=r_{2} \cdot A \cdot \rho_{B}$ \\
\hline 3 & $\mathrm{E} \frac{\mathrm{dX}_{3}}{\mathrm{dZ}}=\mathrm{r}_{3} \cdot \mathrm{A} \cdot \rho_{\mathrm{B}}$ \\
\hline 14 & $w \frac{d X_{14}}{d Z}=r_{14} \cdot A \cdot \rho_{B}$ \\
\hline 15 & $w \frac{d x_{15}}{d z}=r_{15} \cdot A \cdot \rho_{B}$ \\
\hline 16 & $w \frac{d X_{16}}{d z}=r_{16} \cdot A \cdot \rho_{B}$ \\
\hline
\end{tabular}

Nomenclature

$$
\begin{aligned}
& \mathrm{E}^{\cdot} \quad=\text { initial 1b. moles ethylbenzane per sec. } \\
& \text { W = initial 1b. moles steam per sec. } \\
& \text { A = reactor cross-sectional area ( } 5 t .^{2} \text { ) } \\
& r_{i}, i=1,3 \& 14,16 \text { reaction rate expressions (3.3) } \\
& \mathrm{Z} \quad \text { = reactor bed depth (Ft.) } \\
& \rho_{\mathrm{B}}=\text { catalyst bulk density }\left(\mathrm{Lb} \cdot / \mathrm{Ft} .^{3}\right) \\
& \mathrm{X}=\text { mole fraction of } \mathrm{E} \text { or } \mathrm{W} \text { converted }
\end{aligned}
$$

Note: Material balance calculations for a 2-Bed reactor system are to be found in Appenuix 7 .

\subsection{Energy Balance}

Over a reactor section $\mathrm{dz}$, the energy balance may be 
written:

$$
\begin{gathered}
-E \sum_{i=1}^{3} \frac{d X_{i}}{d Z} \cdot \Delta H_{i}-N \sum_{i=14}^{16} \frac{d x_{i}}{d Z} \cdot \Delta H_{i}-U\left(T-T_{S}\right) \frac{4 \alpha}{D} \\
=\sum_{j=1}^{14} n_{j} c_{p_{j}} \cdot \frac{d T}{d Z}
\end{gathered}
$$

Under adiabatic conditions the third term of the L. H. S. disappears leaving

$$
\frac{d T}{d Z}=\frac{-E \sum_{i=1}^{3} \frac{d X_{i}}{d Z} \cdot \Delta H_{i}-w \sum_{i=14}^{16} \frac{d x_{i}}{d Z} \cdot \Delta H_{i}}{\sum_{j=1}^{I L} n_{j} C_{p_{j}}}=\frac{N}{D}
$$

When treating $\mathrm{dT}$ as a finite difference (i.e. when $T$ is not incluxed in the Runge-Kutta Integrtion), we may write

$$
\begin{aligned}
\Delta \mathrm{T} & =\frac{\mathrm{N} \cdot \Delta \mathrm{Z}}{\mathrm{D}} \\
\mathrm{T}_{1} & =\mathrm{T}_{1-1}-\Delta \mathrm{T}
\end{aligned}
$$

* 14 conpounds were considered

3.6 Pressure Drop

$\cdot \quad$ The rate of change of pressure with bed depth is found by the Ergun Equation?.

$\frac{d P}{d z}=\frac{v_{o}(1-\epsilon)}{D_{p} \epsilon^{3}}\left(\frac{150 \mu(1-\epsilon)}{D_{p}}+1.75 v_{o} \rho_{g}\right) \frac{1}{144(14.7) g_{c}}=R$ 


\section{NOMENCLATURE USED IN ENERGY BALANCE}

E . Initial 1b. moles ethylbenzene per sec.

W Initial $1 \mathrm{~b}$. moles steam per sec.

$\mathrm{X}_{1}$ Mole fraction of $\mathrm{E}$ or $\mathrm{W}$ converted

Z. Bed depth - (Ft.)

$\Delta \mathrm{H}$ Heat of Reaction (BTU/Lb.Mol.)

$\mathrm{U}$ Reactor Surroundings heat transfer coefficient (BTU/sec.ft. $\left.{ }^{2} o_{K}\right)$

T Reactor Temperature at bed depth $\mathrm{Z}\left({ }^{\circ} \mathrm{K}\right)$

$\mathrm{T}_{\mathrm{S}} \quad$ Ambient temperature $\left({ }^{\circ} \mathrm{K}\right)$

$Z$. Reactor cross sectional area (Ft. ${ }^{2}$ )

D Reactor diameter (Ft.)

n Component flow rate Lb.mol./sec.

$\mathrm{C}_{\mathrm{p}}$ Component heat capac1ty $=\left(\mathrm{BTU} / \mathrm{Lb} \cdot \operatorname{mol} \mathrm{O}_{\mathrm{K}}\right)$ 
Treating $P$ over a finite differcnce we get

$$
\begin{aligned}
& \Delta P=R \times \Delta Z \\
& P_{i}=P_{i-1}-\Delta P
\end{aligned}
$$

Note: In all runs mentioned in this report, the Ergun equation was missing the $v_{0}$ of the turbulent flow contribution to pressure drop. The equation actually used reads

$$
\frac{d P}{d z}=\frac{v_{o}(1-\epsilon)}{D_{p} \epsilon^{3}}\left(\frac{150 \mu(1-\epsilon)}{D_{p}}+1.75 \rho_{g}\right) \frac{1}{144 . g_{c} \cdot 14.7}
$$

where $\epsilon=0.35$.

When the equation is used in the correct for a, $\epsilon=.445$ must be used in order to simulate the observed plant pressure drop. Bjth pressire drop equations give the same results for all extrenes of variables met in the parameter and optimization searches. Appendix 15 conpares the two equations and shows that we nay have complete confiance in the reported search optina.

Nomenclature

$$
\begin{aligned}
& P \quad=\text { atmospheres } \\
& v_{0} \quad=\text { superficial velocity (Ft./Sec.) } \\
& \epsilon \quad=\text { voidage fraction } \\
& Z \quad=\text { bed depth (Ft.) } \\
& D_{p} \quad=\text { catelyst particle dianeter (Ft.) } \\
& \left.\rho_{g} \quad=\text { gas density ( Lb./ft. }{ }^{3}\right)
\end{aligned}
$$


Nomenclature_-Continued

$$
\begin{aligned}
& \mu \text { = viscosity of mixture }{ }^{*} \\
& \text {. }=.03 \times 6.72 \times 10^{-4} \text { (Lb./ft.sec.) } \\
& \mathrm{g}_{\mathrm{c}}=32.2 \text { (Lb. nass } \mathrm{x} \mathrm{ft.} / \mathrm{lb} \text {. force } \mathrm{x} \mathrm{sec.}{ }^{2} \text { ) } \\
& 14.7=1 \mathrm{~b} . / \text { in. }^{2} \text { atmos. } \\
& \text { 144. }=\text { in. }{ }^{2} / \text { t. }^{2}
\end{aligned}
$$

Reactor Inlet Pressure - Visual observation of the 29 cases comprising the POLY-29 case ( 4.1 and 5.3 ) inalcated that inlet pressure seened to be a linear function of the total nolar flow. The following expression resulted:

$$
P=1.046+.00122 \times S
$$

where $P=$ atmospheres

$S=$ Lb. moles/hour in total nixed f'eed stream.

* FoUST, $\Xi . F$. et al, Principles of Unit Operations, Wiley, p. 557 (1962). A constant value of $\mu$ was used, i.e. $\mu$ of water vapour at high temperatures.

\subsection{Heats of Reaction}

The heats of reaction are expresserl as linear functions of temperature over the range of tonperatuje considered. In general,

$$
\Delta H_{i}=a+b T
$$

where

$$
\begin{aligned}
\Delta \mathrm{H} & =\text { cal./gmenole } \\
\mathrm{T} & =\mathrm{O}_{K}
\end{aligned}
$$




\section{a and b values:}

\begin{tabular}{c|c|c|c}
$\begin{array}{l}\text { REACTION } \\
\text { NUMBER }\end{array}$ & $\mathrm{a}$ & $\mathrm{b}$ & $\begin{array}{c}\text { REFERENCE } \\
\text { NUMBER }\end{array}$ \\
\hline 1 & 28843 & 1.09 & 1 \\
2 & 25992 & -1.90 & 1 \\
3 & -12702 & -3.15 & 1 \\
14 & 19602 & 2.11 & 2 \\
15 & 50460 & 3.96 & 2 \\
16 & -10802 & 2.50 & 2
\end{tabular}

* References are given following 3.8

\subsection{Heat Canacities}

Heat capacities are expressed as quadratic functions of temperature. The relation $d(\Delta H) / d T=C_{p}$, implies that

$\Delta H$ should be in cubic form to be consistent with a quadratic $C_{p}$ function. However little error is introduced by the linear $\Delta H$ assumption (Appendix 4 ).

$$
c_{p}=a+b T+c T^{2}
$$

where:

$$
\begin{aligned}
& C_{p}=\text { Cal./gm.mole }{ }^{O} \mathrm{C} \text {. or BTU/1b.mole }{ }^{O} \mathrm{~F} . \\
& T={ }_{K}
\end{aligned}
$$




\section{Table of $C_{p}$ Values}

\begin{tabular}{|c|c|c|c|c|c|}
\hline $\begin{array}{l}\text { PROGRAM } \\
\text { COMPOUIND } \\
\text { NUIBER }\end{array}$ & CONPONENT & a & $\mathrm{b}$ & $\begin{array}{l}c \\
\times 10^{-6}\end{array}$ & $\begin{array}{l}\text { RREATERENCE } \\
\text { NUNBRE }\end{array}$ \\
\hline 1 & Ethylbenzene & 2.23 & 110. & -36.7 & 4 \\
\hline 2 & Styrene & 4.07 & 97.7 & -33.1 & 4 \\
\hline 3 & Hydrogen & 6.947 & -0.2 & .481 & 3 \\
\hline 4 & Ethylene & 2.83 & 28.601 & -8.726 & 3 \\
\hline 5 & Benzene & -4.09 & 77.621 & -26.426 & 3 \\
\hline 6 & Toluene & .576 & 93.493 & -31.227 & 3 \\
\hline 7 & Methane & 3.381 & 18.044 & -4.3 & 3 \\
\hline 8 & Ethane $*$ & 2.247 & 38.201 & -11.049 & 3 \\
\hline 9 & Acetylene & 7.331 & 12.622 & -3.889 & 3 \\
\hline 10 & $\begin{array}{l}\mathrm{C}_{6} \mathrm{H}_{5} \mathrm{C}_{2} \mathrm{H}^{*} \\
\text { (ethynylbenzene) }\end{array}$ & 3.47 & 91.9 & -31.4 & 4 \\
\hline 11 & Stean & 7.256 & 2.298 & .284 & 3 \\
\hline 12 & Carbon Monoxide & 6.42 & 1.665 & $-\quad .196$ & 3 \\
\hline 13 & Carbon Dioxide & 6.214 & 10.396 & -3.545 & 3 \\
\hline 14 & Carbon & 4.10 & 1.02 & 0 & 3 \\
\hline
\end{tabular}

* These compounds do not appear in the model

* See Appendix 14

References for $\Delta H$ and $C_{p}$ formulae

RETEREITCE

NUNTBER

1 WENER, R. R., and E. C. DYBDAL, Chen. Ing. Prog. Vol. 44, No. 4. 275 (1948) - their values were taken fron A. P. I. 44 
REFERENCE

NUMBER

2

3

4

\section{REFERENCE}

Calculated from Smith and Van Ness $C_{p}$ data.

- Same reference as 3 .

SMITH, and VAN NESS, "Introduction to Chemical

Englneering Thermodynamics", McGraw-H1ll (1959).

BOUNDY, R. H. and R. F. BOYER, Styrene, Its Polymers,

Copolymers and Derivatives, Reinhold' (1952).

$\mathrm{C}_{\mathrm{p}}$ in form $\mathrm{a}+\mathrm{bT}+\mathrm{cT}^{2}$ was regressed from $\mathrm{C}_{\mathrm{p}}$ vs.

T data in this text.

\subsection{Calculation}

The six material balances, with $\mathrm{X}_{1}=0$, at the reactor entrance, have been solved simultaneously with the Fourth Order Runge-Kutta-Gill method of integration. Temperature and pressure have been dealt with by holding them constart over each integration step; they are updated at the end of every such increment.

A complete Fortran IV listing of the model is given in Appendix 5 . 
4. DATA

4.1 Data Available

It is necessary to discuss the data available and to point out some of their shortcomings. Polyner had run a factorial design with twenty-nine steady-state situations (to be referred to as Poly-29) in order to find a regression equation to describe the reactor. Only the information shown in Table 1 under Poly-29 was recorded. Mean values of all 29 cases are shown. Neither gas analysis, nor reactor exit temperature, nor any internal reactor temperature was available.

In April, May and June, 1966, data were taken representing mean conditions for periods of 1 to 5 days operation (Table 1 ). The gas compositions (Mole, \%) are only useful for determining the relative amount of each gaseous compound since absolute amounts could not be calculated. Although the reactor exit temperatures were taken, still no internal values were known. The nodel was created without knowledge of the reactor tenperature profile.

Only in late June and August, 1966, were temperature profiles taken. These profiles (Table 2) are discussed in Section 5.7 and indicate that the real situation is close to an adiabatic one. The exact location of the thermocouples in the bed is shown in Figure 3 depicting the reactor. The temperature profiles of Table 2 are conpared to the nodel 


\section{TABLE 2}

TEMPERATURE PROF ILE DATA

\begin{tabular}{l|cccccc} 
& $\begin{array}{c}\text { TRC-9 } \\
0_{K}\end{array}$ & $\begin{array}{c}\text { TI-1-70 } \\
0_{K}\end{array}$ & $\begin{array}{c}\text { TI-I-71 } \\
0_{\mathrm{K}}\end{array}$ & $\begin{array}{c}\text { TI-1-72 } \\
\mathrm{O}_{\mathrm{K}}\end{array}$ & $\begin{array}{c}\text { TI-2-73 } \\
\mathrm{O}_{\mathrm{K}}\end{array}$ & $\begin{array}{c}\text { TI-2-74 } \\
\mathrm{O}_{\mathrm{K}}\end{array}$ \\
\hline JUNE $^{\mathrm{X}}$ & 920.33 & $928.56^{\mathrm{y}}$ & 916.96 & 882.16 & 872.36 & 857.56 \\
AUGUST & 919.80 & $908.8^{\mathrm{y}}$ & 911.00 & 869.00 & 854.80 & 850.60 \\
\hline $\begin{array}{c}\text { BED DEPTH } \\
\text { Z (FT.) }\end{array}$ & 0.0 & 0.0 & 0.5 & 2.18 & 4.52 & 5.5833 \\
& & & & & &
\end{tabular}

Notes: $x$ - The JUINE temperature profile data was not taken at the same time as the June case of Table 1 .

y - The values of temperature at TI-1-70 seen erratic and have been.discarded. 


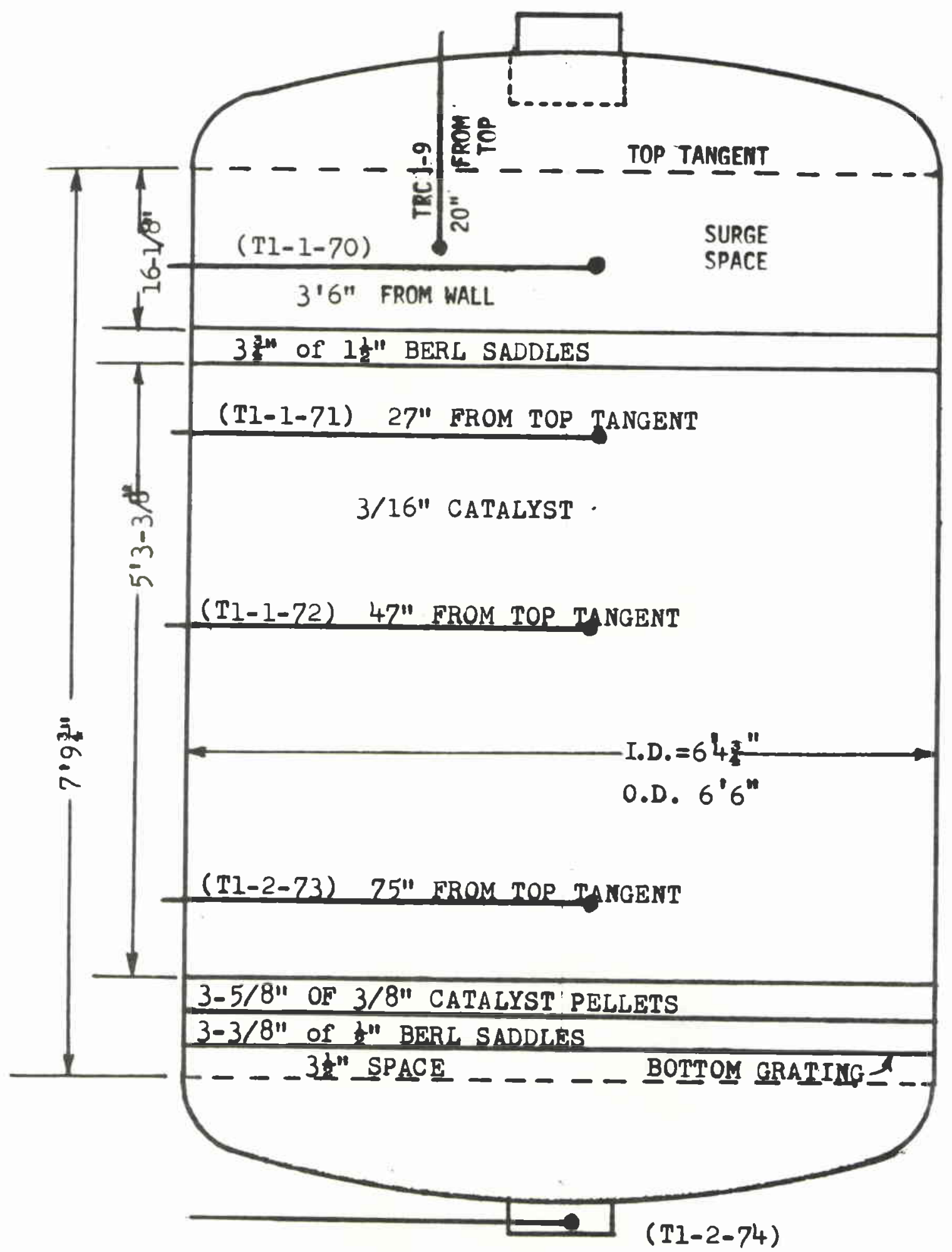


profile in Section 5.7 , Figure 12.

\subsection{Project Iinitations}

Because available data were limited, the full potential of the project could not be realized. The catalyst has a useful life of about two years at the end of which it must be changed due to fouling. Since the data spanned a period of only three months, the decline of efficiency with tine and bed depth could not be observed. It was impossible to deternine the overall, long term optimum operating policy. A best operating policy could only be obtained for an instant in the catalyst's life, ignoring its possible acceleration of loss of efficiency.

All optimization studies were made on the April case, 1.e. a moment in the life of the catalyst. Simply then, the data do allow a model of the reactor where the frequency factors must be changed according to the case being run.

In summary, it is possible to estaklish a temporary optimum operating policy, keeping in mind that this choice may not be beneficial to the long term optimum policy. With data covering the entire span of catalyst life, the long term policy can be found by the inclusion of time-deperdent factors to depreciate the catalyst efficiency.

\subsection{Treatment of Data - Simplifications}

The absolute (Ib./hr.) flows of Iiquid product and product gas were not available nor could the anount of gas be, related to the amount of liquid since the gas analysis was in mole $\%$. Assumptions had to be made in order to get the absolute 
flows of the product streans. It was assumed that the feed and liquid product wt. \% analysis (by gas chromatograph) were precise. Also, as shown by the choice of reactions (3.2), it was assumed that none of the aromatic nuclei would decompose, and that all the aromatic compounds would appear only in liquid product. Thus it was possible to carry out a material balance on the aromatic ring compounds.

A ratio, $R$, the Ibs. feed/Ib. liquid product, was used to facilitate calculations. For a reasonable choice of $\mathrm{R}, \mathrm{a}$ typical calculation (for the April case) went as follows:

$\mathrm{R}=1.05 \quad$ Basis $=9000 \mathrm{lb}$. total hydrocarbon feed Liquid Product Flow $=9000 \times \frac{100}{105}=8571.67 \mathrm{lb} . / \mathrm{hr}$.

$\left.\begin{array}{l|c|c}\text { COMPOUND } & \text { LB./HR. } & \text { LB.MOL./HR. } \\ \hline \text { Ethylbenzene } & 8571.67 \times .51530=4416.85 & 39.694 \\ \text { Styrene } & 8571.67 \times .40463=3468.25 & 31.830 \\ \text { Toluene } & 8571.67 \times .04665=399.86 & 2.400 \\ \text { Benzene } & 8571.67 \times .02924=250.62 & 2.971\end{array}\right\} \sum=37.201$

For this case if we assune conservation of aronatic nuclei we have an inconsistency, since 39.694 moles of ethylbenzene have reappeared as only 37.201 moles of styrene, toluene and benzene. Each mole of ethylbenzene decomposed should reappear as a nole of these three products.

By interpolation between a few such calculations, it was found that for a value of $\mathrm{R}=1.019^{(10)}, 38.4281 \mathrm{~b}$. nols. Ib. mols. of ethylbenzene reappeared as $38.444 \mathrm{lb}$. mols. 
of styrene, toluene and benzene. For this case the total liquid product was $8832.431 \mathrm{~b} . / \mathrm{hr}$; $167.57 \mathrm{lb} . / \mathrm{hr}$. of the original $9000 \mathrm{lb} / \mathrm{hr}$. feed had gone in one form or another to the product gas strean. Thus the expected liquid product stream breakdown becones:

$\left.\begin{array}{l|c|c}\text { COMPOUND } & \text { LB./HR. } & \text { LB.MOL./HR. } \\ \hline \text { Ethylbenzene } & 8332.43 \times .51530=4551.22 & 38.428 \\ \text { Styrene } & 8832.43 \times .40463=3573.76 & 32.843 \\ \text { Toluene } & 8832.43 \times .04665=412.02 & 2.532 \\ \text { Benzene } & 8832.43 \times .02924=258.25 & 3.069\end{array}\right\} \quad \Sigma=38.444$

* Note that in the nodel this small fraction of conponents has been onitted.

Further assumptions regarding the gas stream had to be made. Associated with the liquid products of reactions 1, 2 and 3 there is a definite anount and composition of gas $\left(\mathrm{CH}_{4}, \mathrm{C}_{2} \mathrm{H}_{4}, \mathrm{H}_{2}\right)$. Reactions 14 to 16 would be used, by choosing appropriate rates, so that the final gas nole per cent analysis of the model would approach the reported values. The total weight of gas per hour depends on the amount of reaction (of 14 - 16) requirea to bring the model analysis close to that of the existing product gas. 


\section{TESTING OY MODEL}

The subsections 5.1 to 5.6 , to follow, either point out that the model is fundanentally sound or give the results of paranetric studies which show that the nodel reacts as expected to changes in the process variables. Due to its importance, the comparison of the moael temperature profile with the actual is discussed separately in section 5.7.

\subsection{Frequency Factor Searches}

Frequency factors were found by carrying out a search (to be described in Section 7) on their exponents (i.e. $A_{i}$ of $\left.\operatorname{EXP}\left(-\Delta \Xi_{i} / R T+f_{i}\right)\right)$. As exponents were changed according to this search technique, a response function of the form Response $=\sum$ (Expected Amount Component i - Model Anount component i) ${ }^{2}$

was mininized. The values of $A_{1}$ giving the least response were those used in the final model; each case required its own set of frequency factors (see Appendix 3). All sets of frequency factors were found for fifty equal size integration steps.

The resporse included the four najor hydrocarbons (ethylbenzene, styrene, toluene and benzene) only, even though the frequency factors involved in the search represented all six reactions. By changing the $A_{i}$ of reactions 14 to 15 , the 
hydrogen, ethylene and methane amount were adjusted and thus indirectly these exponents controlled reactions 1 to 3 , and so, the response. In each case the product gas anount and composition is as reasonable as can be expected. Wodel results for the April, May, June and Poly-29 cases are given in Table 3; these compare favourably with the expected reactor outputs of Table 1.

Plots of conversion versus the reactor bed depth for all reactions are given for the April case in Figure 4.

\subsection{Runge-Kutta Step Size Studies}

An intensive survey was carried out on the integration step sizes, keeping in mind that speed as well as accuracy was required. Typical results of such a study for two variables, the nixed feed temperature and stean rate to a single reactor, are shown in Table 4. The four major hydrocarbons are traced to convergence by increasing the number of integiration steps. Over the range of steam rate $(5000-30000 \mathrm{lb} . / \mathrm{hr}$.$) and inlet$ temperature $\left(922\right.$ - $\left.1010^{\circ} \mathrm{K}\right)$ studied, the following restrictions on step size nust be adhered to:

\section{RESTRICTIOIN}

$\mathrm{T}<960^{\circ} \mathrm{K}$

$T<960^{\circ} K \& S>22000$

$960^{\circ} \mathrm{K}<\mathrm{T}<985^{\circ} \mathrm{K}$

$985^{\circ} \mathrm{K}<\mathrm{T}<1010^{\circ} \mathrm{K}$

\section{NUMBER OF INTEGRATION STEPS}

50

100

100

150

where $T=$ mixed feed tenperature $\left({ }^{O} K\right)$

$S=$ stean rate (lb./hr.) 


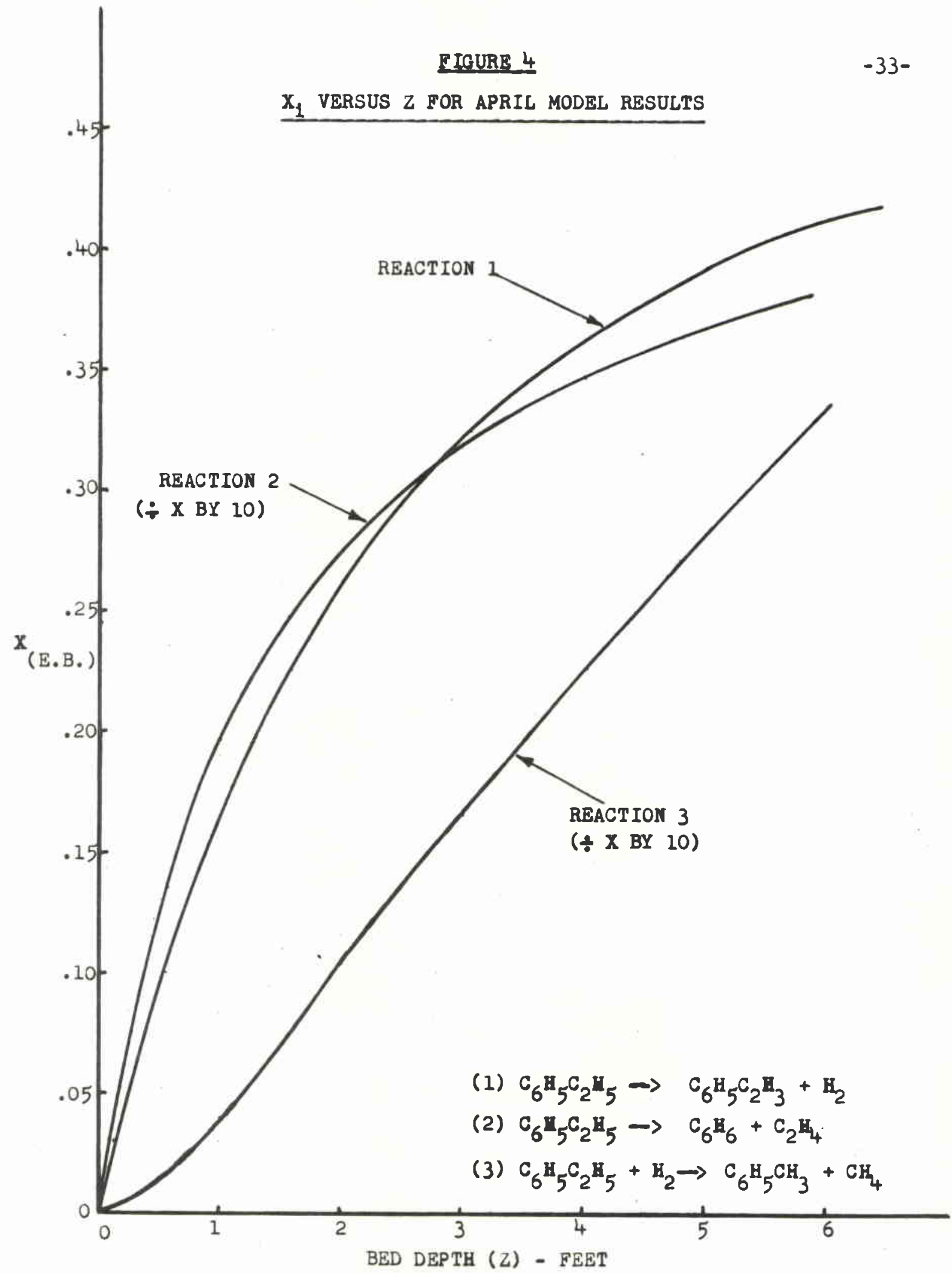


$x_{1}$ VERSUS $\angle$ FOR APRIL MODEL RESULTS

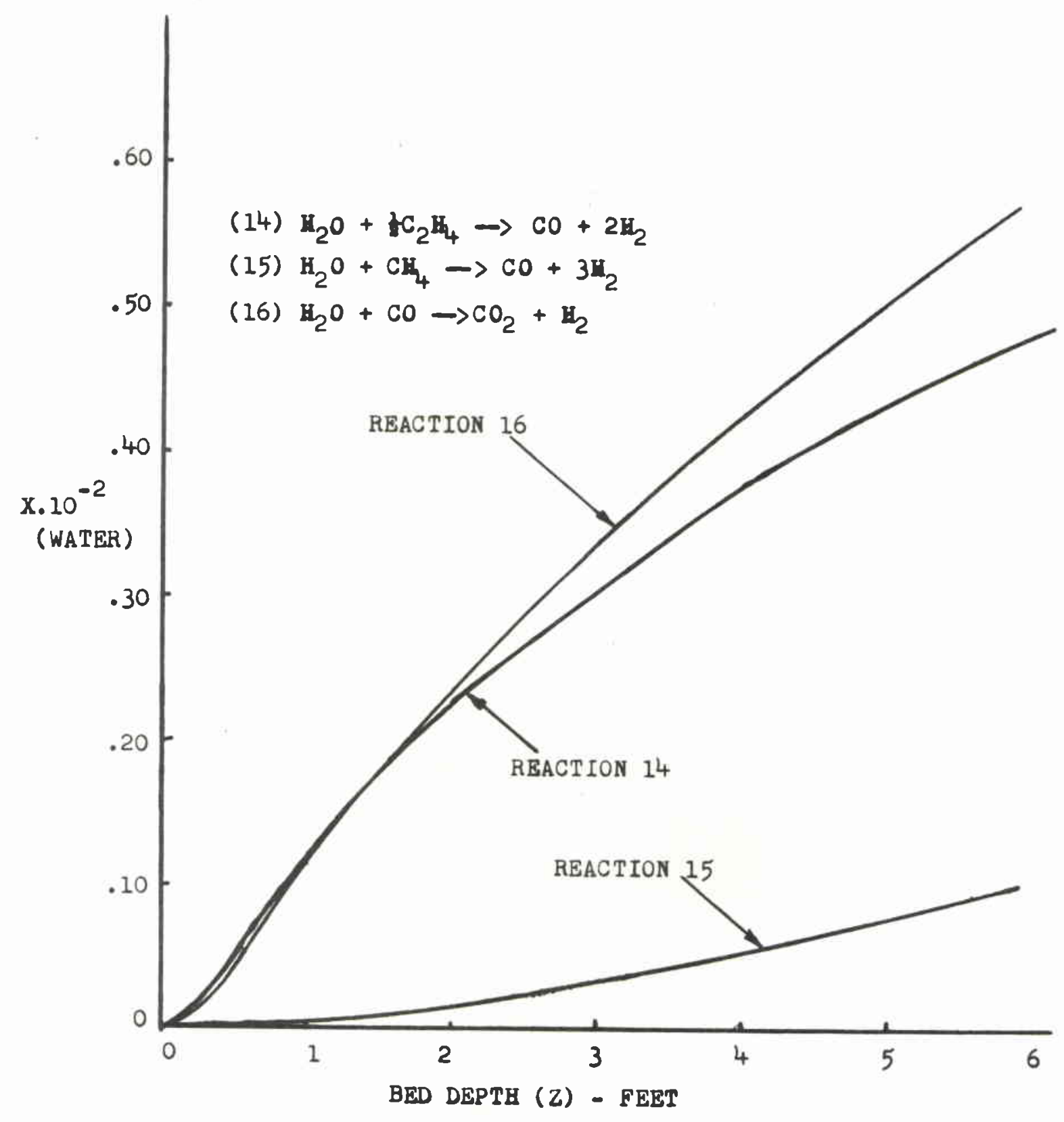




\section{TABLE 4}

SAMPLE RUNEE-KUTTA STEP_SIZE SURVEY

Basis: Standard April Case (Table 3)

Stean rate $=18000 \mathrm{lb} . / \mathrm{hr}$. (Similar surveys were conducted for other steam rates and temperatures)

\begin{tabular}{|c|c|c|c|c|c|c|}
\hline $\begin{array}{l}\text { MIXED } \\
\text { FLED } \\
\text { TENP. } \\
O_{K}\end{array}$ & $\begin{array}{l}\text { IUUBER } \\
\text { OF } \\
\text { INTEGRATION } \\
\text { STHPS }\end{array}$ & $\begin{array}{l}\text { REACTOK } \\
\text { OUTLET } \\
\text { TUMP. } \\
O_{K}\end{array}$ & $\begin{array}{l}\text { PTIYL- } \\
\text { BDHZEiv } \\
\text { LB./rR. }\end{array}$ & $\begin{array}{l}\text { STYRISTE } \\
\text { LB./HR. }\end{array}$ & $\begin{array}{l}\text { TOLUEi } \sqrt{4} \\
\text { LB./FiR. }\end{array}$ & $\begin{array}{l}\text { BDNZLNE } \\
\text { LB./IR. }\end{array}$ \\
\hline EXPEUTAD & $\rightarrow$ (Values & token fi & in Table & 1C) & & \\
\hline 922.59 & 50 & $?$ & 4551.22 & 3573.76 & 412.02 & 258.25 \\
\hline $\begin{array}{l}922 \cdot 59 \\
922 \cdot 59 \\
922 \cdot 59 \\
922 \cdot 59 \\
922 \cdot 59\end{array}$ & $\begin{array}{l}25 \% \\
50 \\
100 \\
150 \\
500\end{array}$ & $\begin{array}{l}852.38 \\
850.75 \\
850.91 \\
850.95 \\
851.03\end{array}$ & $\begin{array}{l}4931.18 \\
4550.58 \\
4559.13 \\
4561.97 \\
4565.95\end{array}$ & $\begin{array}{l}3173.85 \\
3573.64 \\
3570.29 \\
3569.17 \\
3567.59\end{array}$ & $\begin{array}{l}454.40 \\
412.02 \\
410.59 \\
410.11 \\
409.44\end{array}$ & $\begin{array}{l}204.64 \\
257 \cdot 53 \\
254.97 \\
254.12 \\
252.95\end{array}$ \\
\hline $\begin{array}{l}960.00 \\
960.00 \\
960.00 \\
960.00\end{array}$ & $\begin{array}{l}25^{*} \\
50 \\
100 \\
150\end{array}$ & $\begin{array}{l}8 \overline{0} .77 \\
870.91 \\
870.97\end{array}$ & $\begin{array}{l}3575.78 \\
3583.40 \\
3586.44\end{array}$ & $\begin{array}{l}4049.48 \\
4051.19 \\
4052.09\end{array}$ & $\begin{array}{l}562.38 \\
560.81 \\
559.96\end{array}$ & $\begin{array}{l}489.97 \\
484.82 \\
492.64\end{array}$ \\
\hline $\begin{array}{l}985.00 \\
985.00 \\
985.00 \\
985.00\end{array}$ & $\begin{array}{l}25 * \\
50 * \\
100 \\
150\end{array}$ & $\begin{array}{l}834.53 \\
884.09 \\
884.16\end{array}$ & $\begin{array}{l}2980.44 \\
2970.67 \\
2973.60\end{array}$ & $\begin{array}{l}4227.18 \\
4214.55 \\
4218.15\end{array}$ & $\begin{array}{l}680.27 \\
681.55 \\
680.42\end{array}$ & $\begin{array}{l}695.19 \\
710.78 \\
706.87\end{array}$ \\
\hline $\begin{array}{l}1010.00 \\
1010.00 \\
1010.00 \\
1010.00\end{array}$ & $\begin{array}{l}25^{*} \\
50 * \\
100 \\
150\end{array}$ & $\begin{array}{l}89 \overline{8} \cdot 55 \\
897.10 \\
897.19\end{array}$ & $\begin{array}{l}2426.74 \\
2410.63 \\
2413.32\end{array}$ & $\begin{array}{l}4282.06 \\
4231.16 \\
4238.85\end{array}$ & $\begin{array}{l}821.01 \\
808.97 \\
807 \cdot 70\end{array}$ & $\begin{array}{r}942.10 \\
1002.34 \\
995.67\end{array}$ \\
\hline
\end{tabular}

* The integration results are not smooth and/or there are negative concentrations of compounds.

* The frequency factors $\left(A_{i}\right.$ of $\left.\left(e^{-} \Delta E_{i} / R T+A_{i}\right)\right)$ were chosen at this condition. 
Similar checks were required for the two-bed situations. Slight modifications were made to the number of steps to account for pressure, steam rate, and bed length changes; these nay be found in the two-bed model associated with the optinization progremme. (Appendix 11).

Although the integration has not quite converged to steady values (Table 4) at 50 steps when compared to 100, 150 and 500 steps (at $922.59^{\circ} \mathrm{K}$ ), it was decided to use the values of $A_{i}$ found from 50 steps. The slight loss in accuracy is more than conpensated for in the savings in calculation. Since these $h_{i}$ were found for 50 steps, the model is more accurate at 50 steps than at a greater number, the truncation error has been compensated for by the choice of $A_{i}$.

\subsection{Poly-22 Iases}

The twenty-nine runs (4.1) which make up the mean Poly-29 case were each calculated by the model with the frequency factors of the mean case. For these cases, the mixed feed teinperatures varied between $917^{\circ} \mathrm{K}$ and $928^{\circ} \mathrm{K}$, the steam rate was between 14780 and $17220 \mathrm{Ib} / \mathrm{hr}$., and hydrocarbon feed rates ran from 7000 to $90001 \mathrm{~b} . / \mathrm{hr}$. Inlet pressures also varied from about 2.05 atmos. to 2.35 atmos. Mean deviations from the expected amount of the four main hydrocarbons were:

Ethylbenzene

Styrene

Toluene

Benzene
$42.491 \mathrm{~b} . / \mathrm{hr}$.

$19.16 \mathrm{lb} . / \mathrm{hr}$ 。

$0.21 \mathrm{lb} . / \mathrm{hr}$.

(1.91) $1 \mathrm{~b} . / \mathrm{hr}$.

where $(n)$ means less than expected. 
The mean error is less than $1 \%$ for each compound.

Results of the 29 cases are given in Appendix 6 where the simulation and actual product rates for the four najor hydrocarbons are compared.

5.4 Effects of Varying $\Delta \mathrm{E}_{I}$, The Activation Energy

In Section 3.3 we found frequency factors $\left(A_{i}\right)$ to complenent values of $\Delta E_{i}$ taken fron the literature.

Because of the uncertainty ${ }^{11}$ of the value of the activation energy of the main reaction, several runs with different $\Delta E_{1}$ were made. Frequency factor exponents $\left(A_{I}\right)$ were adjusted accordingly so that the $\operatorname{sum}\left(-\Delta E_{1} / R T+A_{1}\right)$ renained as close to that obtained over the whole temperature (T) range for the value of $\Delta E_{1}$ actuaily used (Appendix 2).

$A_{1}$ was chosen for a temperature around the arithmetic mean of the reactor inlet and outlet temperatures. All $\Delta \mathbb{I}_{i}$ and $\mathrm{A}_{i}$ for reactions $2,3,14,15$ and 16 remained as for the April case (Appendices 2 and 3 ). The results are shown in Figure 5.

One can imnediately conclude that it is possible to compensate for a poor value of $\Delta E_{1}$ by the variation of $\hat{A}_{1}$. Better $A_{1}$ 's, for each $\Delta E_{1}$ of Figure 5 , can be found since those used are only crude first approximations.

This work was carried out without knowledge of the 
VARIATION OF $\triangle \mathrm{E}_{1}$, COMPENSATION WITH

CHANGE IN $\Delta_{1}$

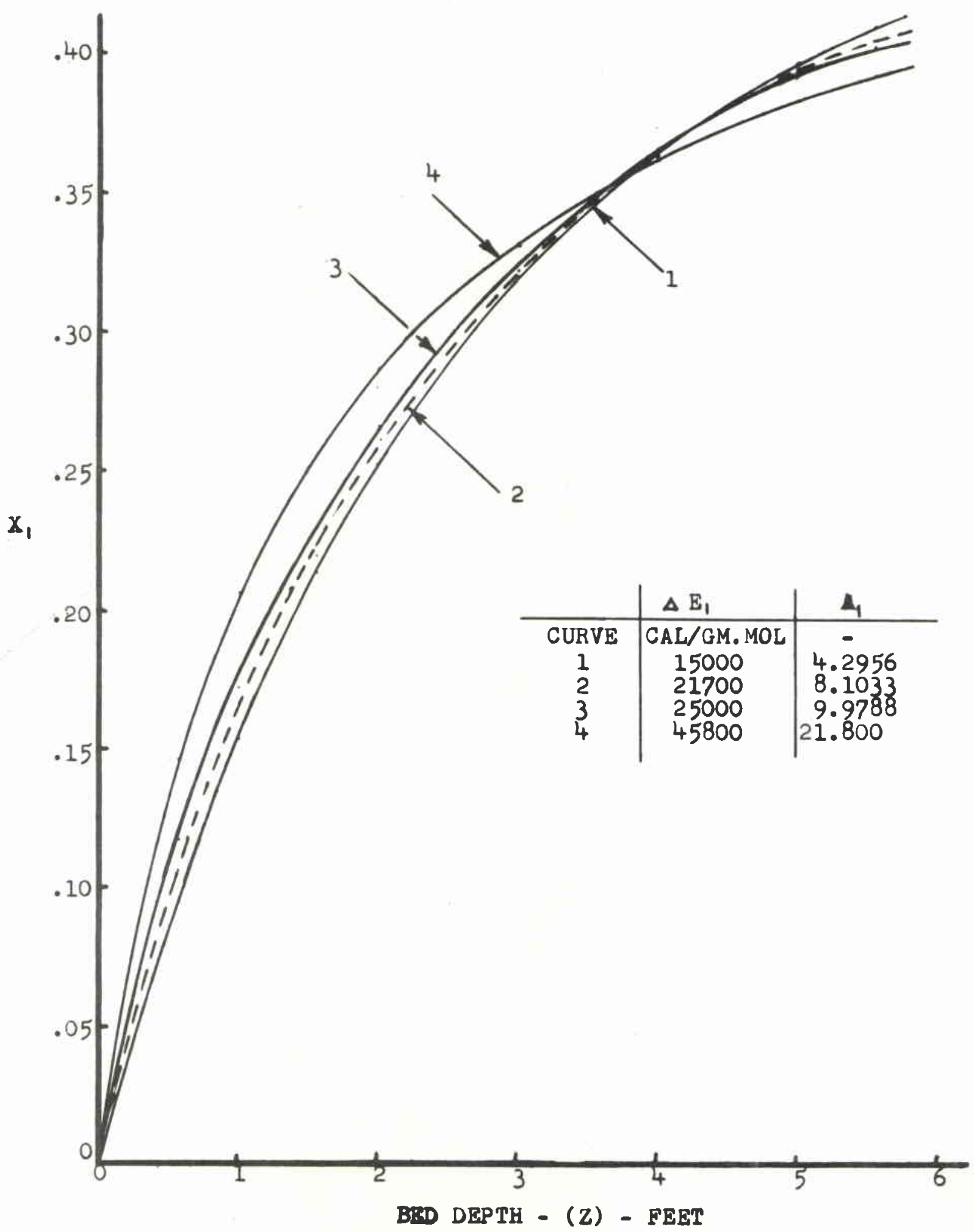


temperature profile. It is evident that the conversion profiles for $\Delta E_{1}$ equal 15000,21800 , and $25000 \mathrm{cal} . / \mathrm{gm} \cdot \mathrm{mol}$. are similar to each other but quite aifferent from that at $45800^{12} \mathrm{cal} . / \mathrm{g} \cdot \mathrm{mol}$. No choice of $A_{1}$ will make the "45800" curve assume the general shape of the other three. Since the main reaction dominates the temperature profile, knowledge of this profile should indicate which X vs. Z curve, and hence which $\Delta E_{1}, A_{1}$ combination is appropriate. In Section 5.7, it is seen that the value of $\Delta E_{1}=21800 \mathrm{cal} . / \mathrm{gra} \cdot \mathrm{nol}$. is a good choice.

Serious error could result should an extrapolation be carried out (i.e. on bed length), if the value of $\Delta E$ of any of the reactions is far from the correct one. For reactions 2, 3 and 14 to 16 a similar situation exists and although some $\Delta \mathrm{E}$ values for these reactions were found over different cataiysts and conditions, it is felt that an error in these $\Delta E_{i}$ has been compensated for by an appropriate choice of $A_{i}$.

\subsection{Parameter Studies}

Parametric studies were carried out only on najor process variables such as stean rate, mixed feed temperature and inlet pressure. In all cases to follow, the April case of Table 1 has been used as basis. The relationships found in these studies are to be of aid in visualizing just how the process variables are interdependent in the optimization studies to follow. 
(1) Variation of Mixed Feed Tenperature - In Figure 6 the rapidy increasing rate of formation of the by-products, benzene and toluene, becomes apparent as the mixed feed temperature is raised. The loss in chenical value to byproducts cannot be made up by the formation of more styrene in the equilibrium limited main reaction and an optimum temperature of operation is found. This optimum comes at 948. $5^{\circ} \mathrm{K}, \mathrm{i} . \mathrm{e}$. Figures 18 and 19 show the mixed feed temperature (H.F.T.) and Gain(W/HR.) in value of the chemicals as a function of the steam temperature and flow rate. This relationship is derived in Section 8.1.1.

Wherever graphs mention conversion $\left(X_{i}\right)$, we may convert to get the $1 \mathrm{~b} . / \mathrm{hr}$. flow rates quite easily. For example at $900^{\circ} \mathrm{K}$ as mixed feed temperature in Figure 6 we get:

STYRIENE RATE = Amt. formed in reaction + initial

$$
\begin{aligned}
& =8630.73 \times .35813 \times \frac{104.14}{106.15}+153.45 \\
& =3185.54 \mathrm{lb} . / \mathrm{hr} .
\end{aligned}
$$

TOEUEITE RATE $=8630.73 \times .021844 \times \frac{92.13}{106.16}+179.74$

$$
=342.36 \mathrm{lb} \cdot / \mathrm{hr} \text {. }
$$

(2) Variation of Steam Rate Only - In Figure 7 only the rate of steam flow has been changed. Inlet pressure remains at 2.37 atiospheres and the temperature of the mixed feed is always $922.59^{\circ} \mathrm{K}$ as in the April case. Results are most meaningful around a steam rate of $19000 \mathrm{lb} / \mathrm{hr}$. 
(3) Variation of Stean Rate and Inlet Pressure is a Function of Molar Flow Fiate - Here, as steam rate was varied, the inlet pressure was treated as a linear function of the total molar flow (i.e. $P=(a+b \times$ total moles/hr. $))$. A comparison of Figure 8 with Figure 7 shows crude relationships between inlet pressure and the conversions, $X_{i}$, at fixed steam rate and inlet temperature.

(4) Variation of Mixed Feed Temperature Over a Large Range With a steam rate of $18000 \mathrm{lb} / \mathrm{hr}$. and inlet pressure of 2.37 atmospheres, runs were made at different inlet teinperatures and compared to the April. case. Figures 9 and 10 offer $X_{i}$ vs. Z plots for the three main reactions at various mixed feed temperatures. The rapid rate of increase of by-products is contrasted to the relatively slow rate of increase of styrene formation.

(5) Variation of Inlet Pressure Only - Only inlet pressure has been varied for the April case (stean rate = $18000 \mathrm{lb} . / \mathrm{hr}$, T.M.F. $\left.=922.59^{\circ} \mathrm{K}\right)$. It is evident that a pressure greater than 2.37 atmospheres does not aid the main reaction conversion. Reaction 3 (seconỏ order) is seriously affected by an increase in pressure and since the overall conversions of reactions 1 and 2 remain approximately constant, a lower operating pressure is sugjested. Figure 11 complements Figures 7 and 8 and all three should be looksd at together for relationships dealing with pressure and stecin rate. 
VARIATION OF MIXED FEED TEMPERATURE - APR IL CASE

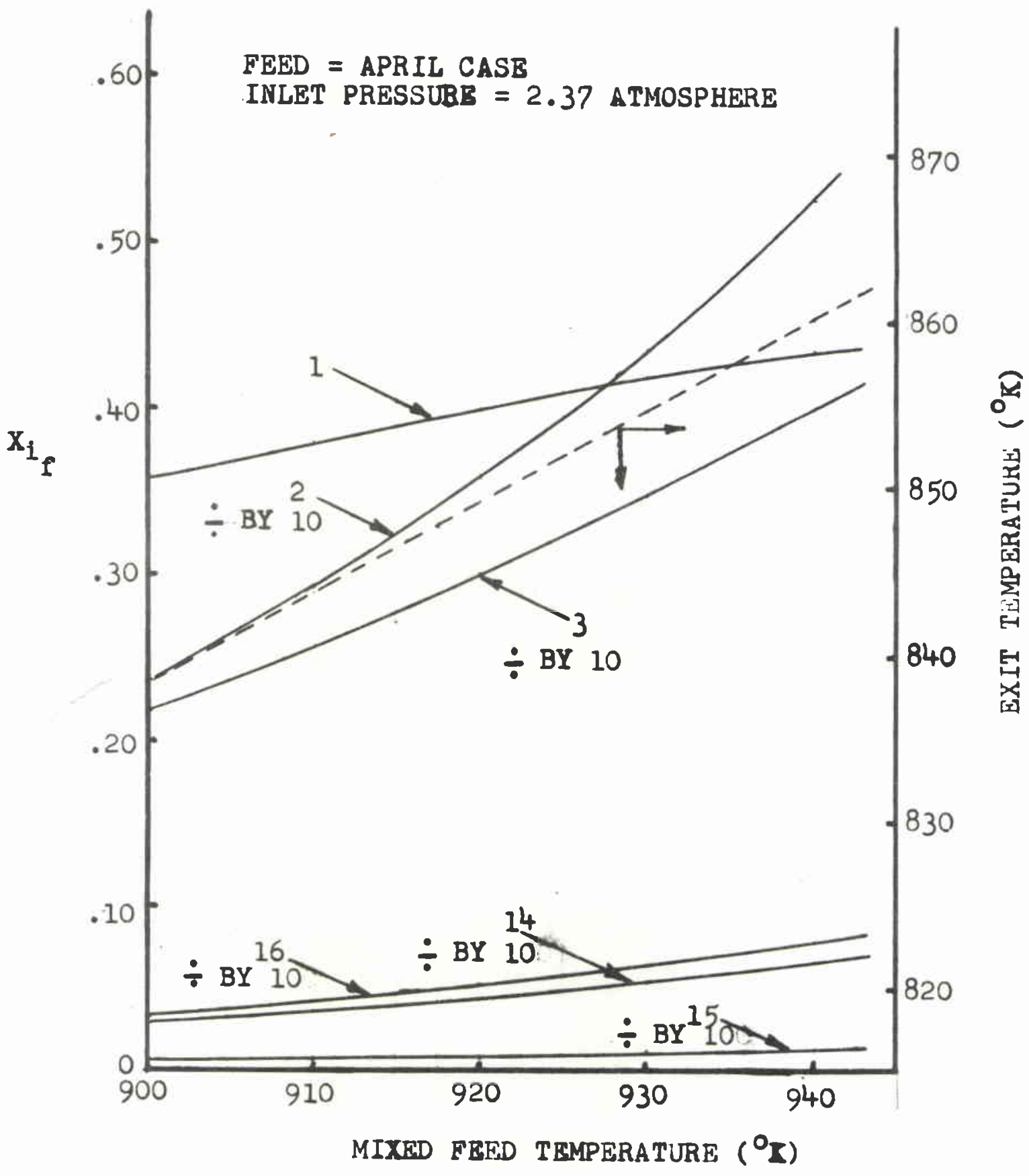




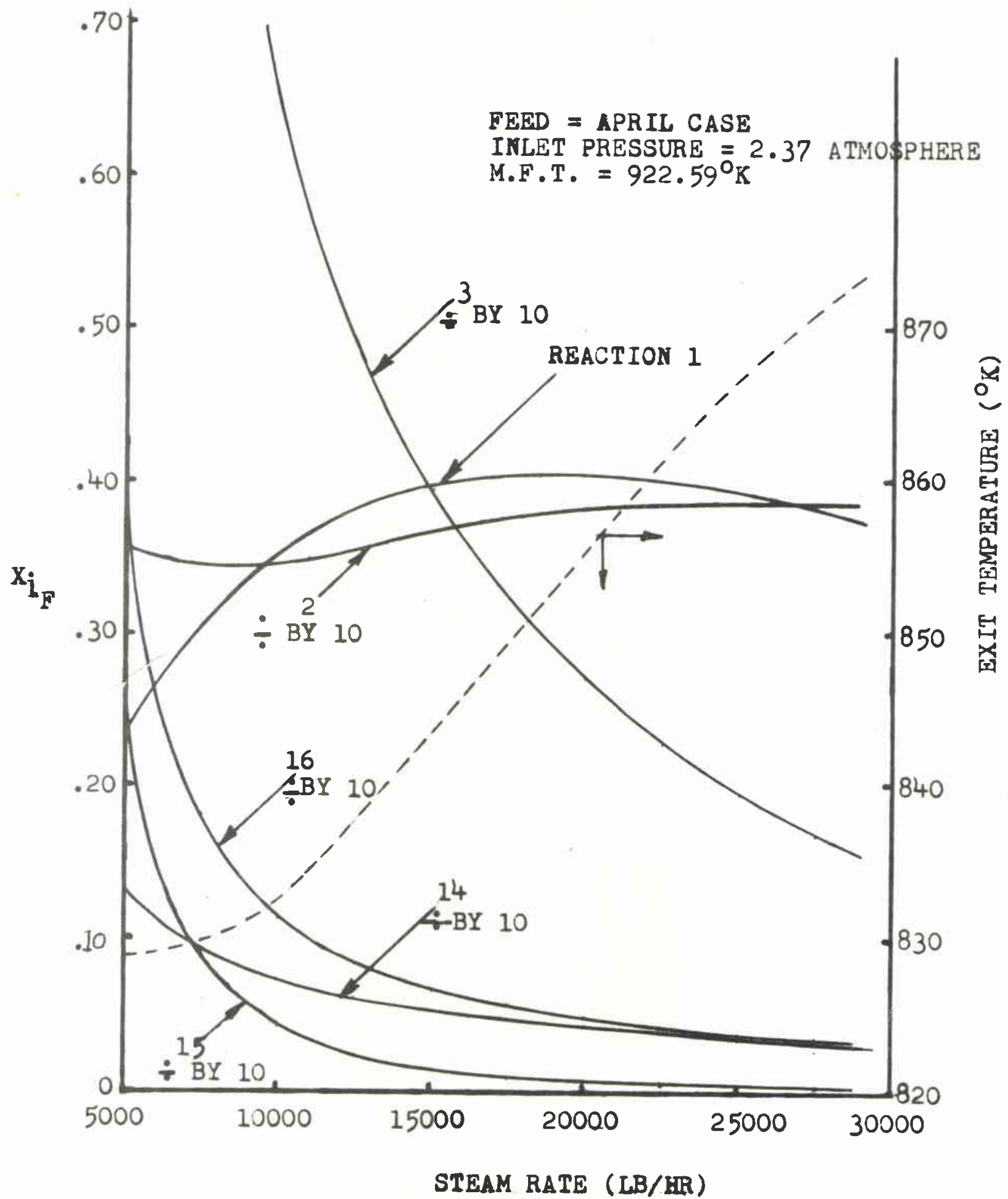


FIGURE_8

VARIATION OF STEAM RATE AND INLET PRESSURE

IS A FUNCTION OF MOLAR FLOW RATE

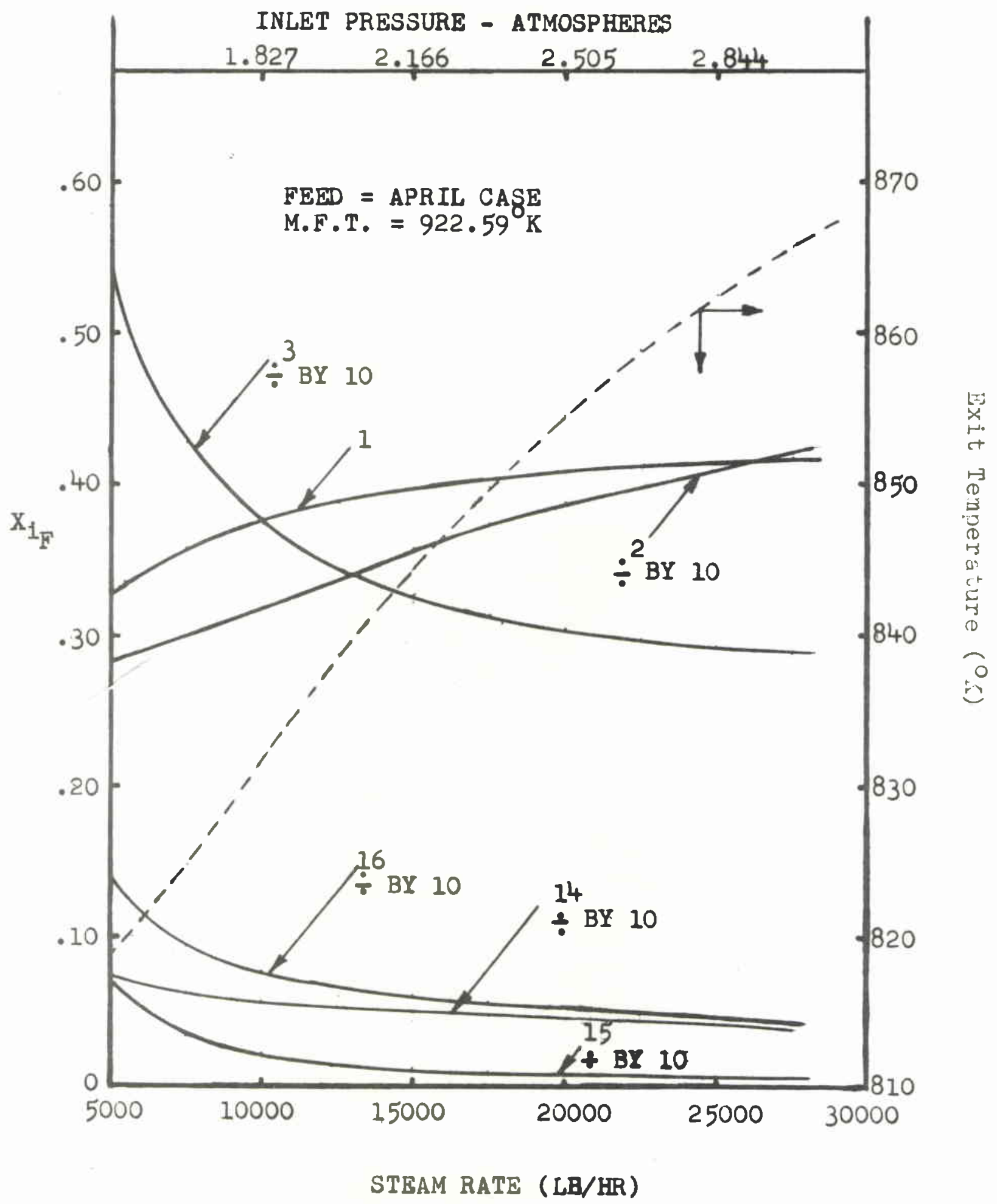




\section{YRRSUS Z - MACN BEACTIOH - YARIOUS M.F.TE}

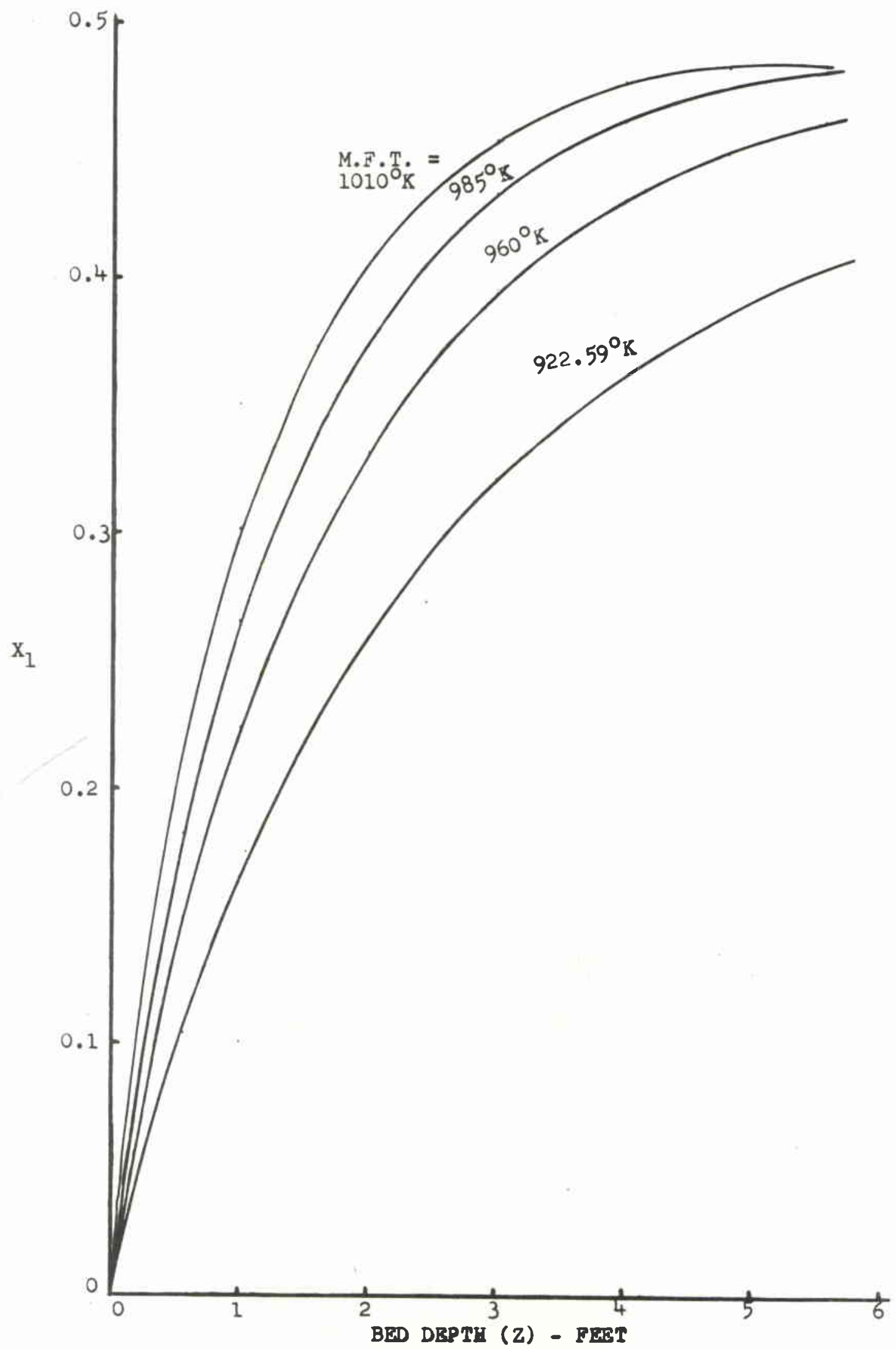


XVERSUS 4 - SIDE REACTIONS - VARIOUS M.F.T.

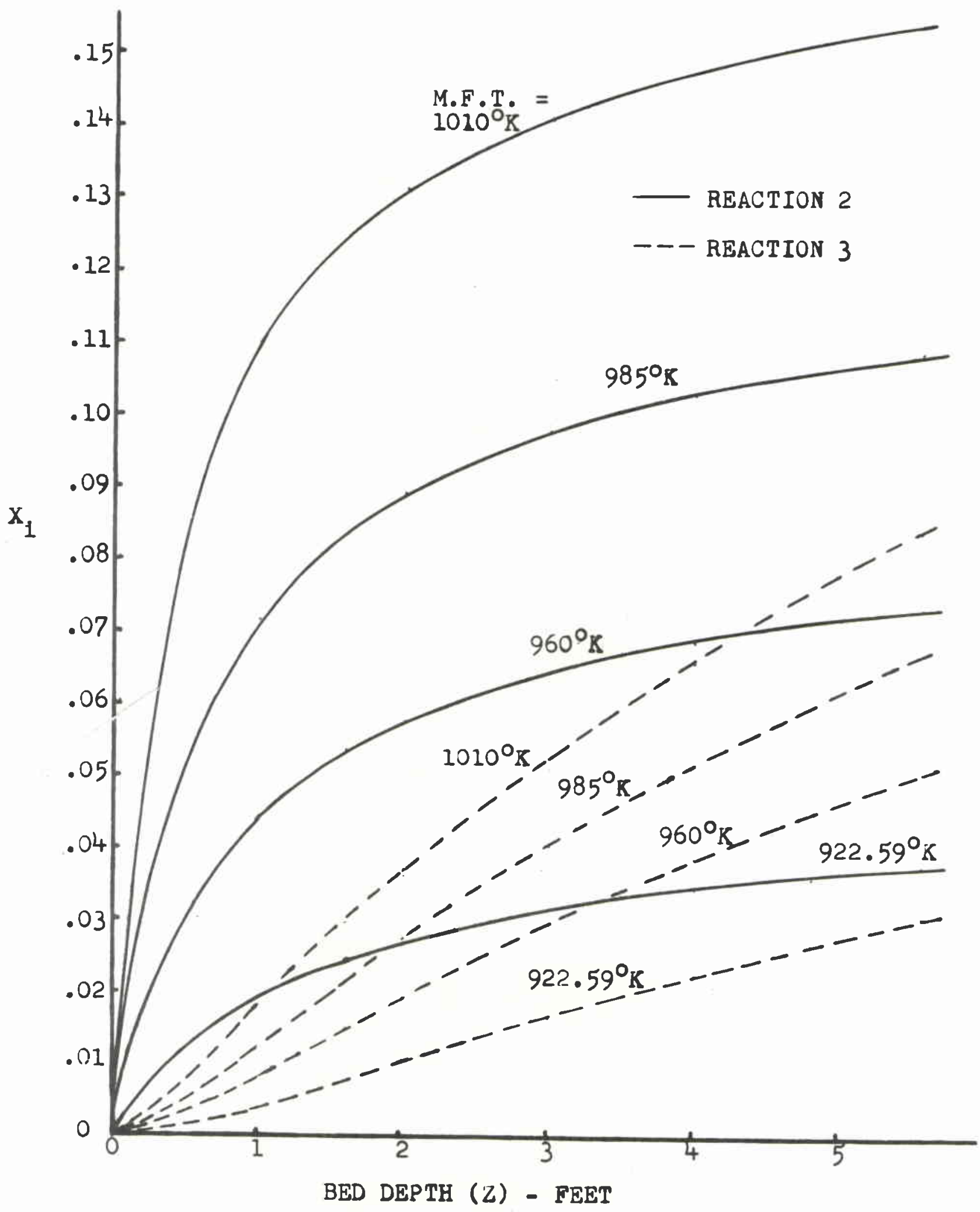




\section{VARIATION OF INLET PRESSURE ONLY}

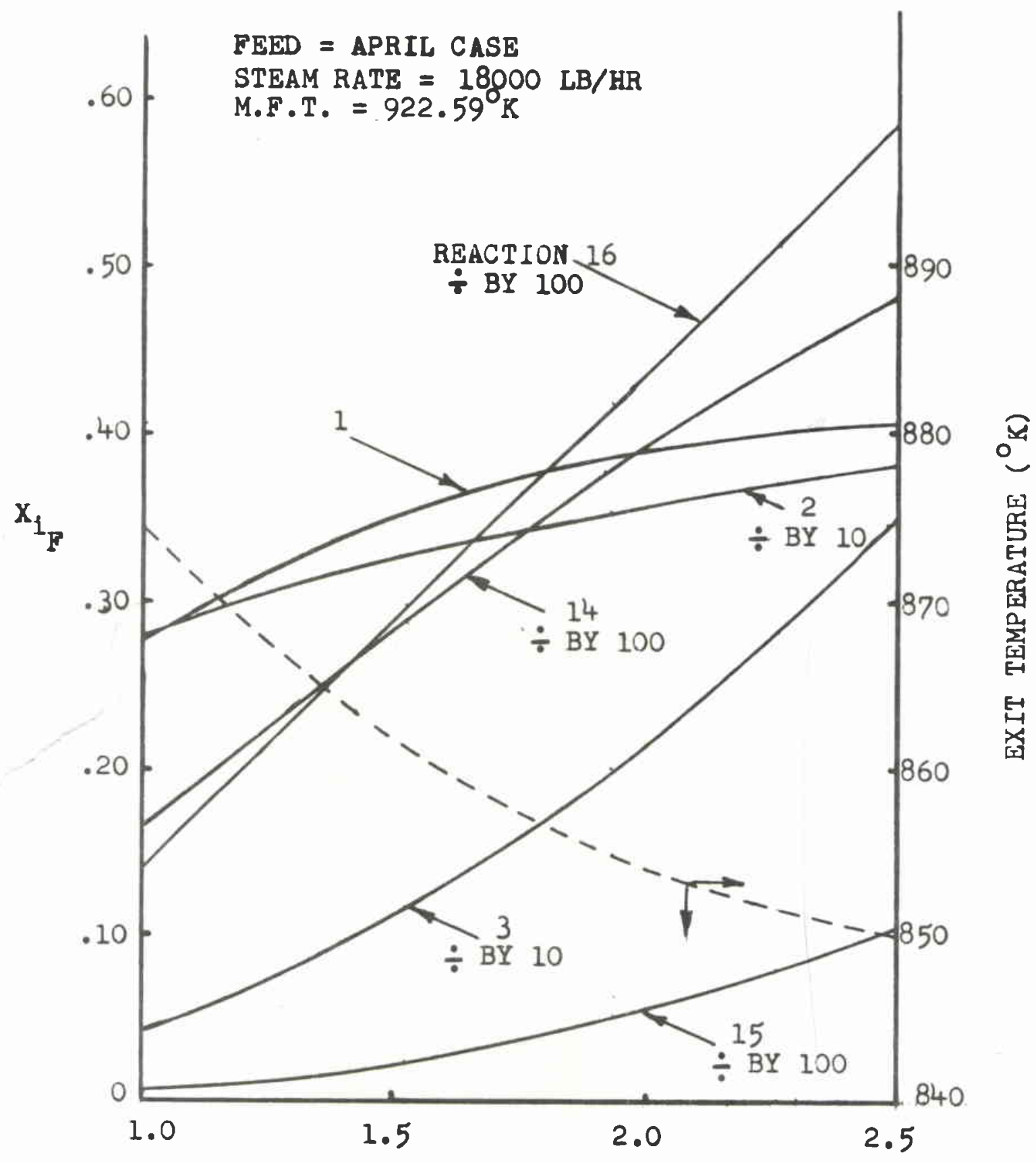

INLET PRESSURE - ATMOSPHERE 


\subsection{Reliability of Molel}

It is difficult to assess the worth of the model without having proven it at different conditions (at the same catalyst afe) fron those for which it was conceived. The problen arises that since the plant presently operates at maximua capacity (shown later by optinization stuaies), limited by constraints, there is no roon for changes in the process variables without incurring a loss of production. Although the Poly-29 case differs from those of April, May and June, the catalyst age is also different and therefore they cannot be compared.

The twenty-nine cases comprising the Poly-29 case (Table 1) were run with the frequency factors obtained from this nean case (5.3). The reproducibility of each case was excellent (Appendix 6). Any discrepancies can be explained by the use of a mean set of frequency factors which represent a period of about three months of the catalyst life.

A quick glance at the $x_{i}$ vs. $z$ plots of the April case (Figure 4) shows that the reactions behave as expected ${ }^{5}$. The main reaction rate slows down as the reverse reaction becoles important and the ethylbenzene concentration falls. Benzene (reaction 2) production falls of $f$ with decreasing ethylbenzene. The third reaction is slow at first, since hydrogen must first be proauced so that it nay occur. Initially the rate increases due to a high concentration of both hydrogen and ethylbenzene and then falls of $f$ as ethylbeizene concentration drops. A 
decrease of tenperature in the reactor slows down all three reactions (Figures 6,9 and 10 ).

Reactions 14 and 15 depend on the ethylene of reaction 2 and methane of reaction 3, respectively. Since ethylene is produced inmediately, reaction 14 proceeds from the reactor mouth at alnost constant rate. Reaction 15 lags reaction 3 which itself must wait for hydrogen and hence is very slow at first; the rate increases as more methane becones available. Carbon dioxide is produced immediately in reaction 16 fron the carbon monoxide of reactions 14 and 15, thus accounting for the very low monoxide analysis. In reactions $14-16$ the steam concentration renains almost constant.

When the inlet temperature is raised from $900^{\circ}$ to $940^{\circ} \mathrm{K}$ (Figure 6 ), the conversion of the main reaction incheases fron about 0.36 to 0.435 at a decreasing rate. However, reactions 2 and 3 proceed at increasing rates from 0.0235 to 0.0525 , and 0.022 to 0.040 , respectively. Overall conversions of reactions $14-16$ depend on reactions 2 and 3 and they increase much quicker than does that of the main reaction and hence, at higher temperatures, any gain in production of styrene is offset by much higher production of the by-products, benzene and toluene.

It would appear that the model is adequate and represents the plant reactor quite well. Optinization studies, which follow, will further demonstrate the model's consistency and ability to show the correct ${ }^{5}$ direction of change to be 
chosen for plant variables in order that the optimuin be reached.

\subsection{Discussion of Temperature Profiles}

The model was founded solely on conversions of the various reactions and on the assumption that the reactor was operating adiabatically. Internal reactor tenperatures were unavailable. A temperature profile would have given an excellent indication of the extent of the main reaction at any reactor bed depth.

Two tenperature profiles were received in late June and in August (Table 2). The former (Figure 12) lies consistently above the model profile. It was assumed that sone malfunction in the neasuring device had caused such a consistent shift.

A check of the thernocouples and the measuring device was well varranted. The resulting August profile (Figure 12) does not vary by more than $5^{\circ} \mathrm{K}$ from the calculated June prorile, and this is well within the possible error of thermocouples operating at the temperatures involved. The natching of calculated and actual temperature profiles lends much confidence to model extrapolations, etc. The exit temperatures which had been recorded for all cases of Table 1 were assumed to have errors similar to that of the June profile and thus were given no weight in deternination of the worth of the model.

Since the TI-1-70 (temperature neasuring devices are 
referred to by the Polyner Corporation nonenclature) temperature readings were erratic, they were discarded altogether; the reactor inlet tenperature of the plant profiles was thus taken fron TRC-9, as it had been for the various molel cases of Table 1. 


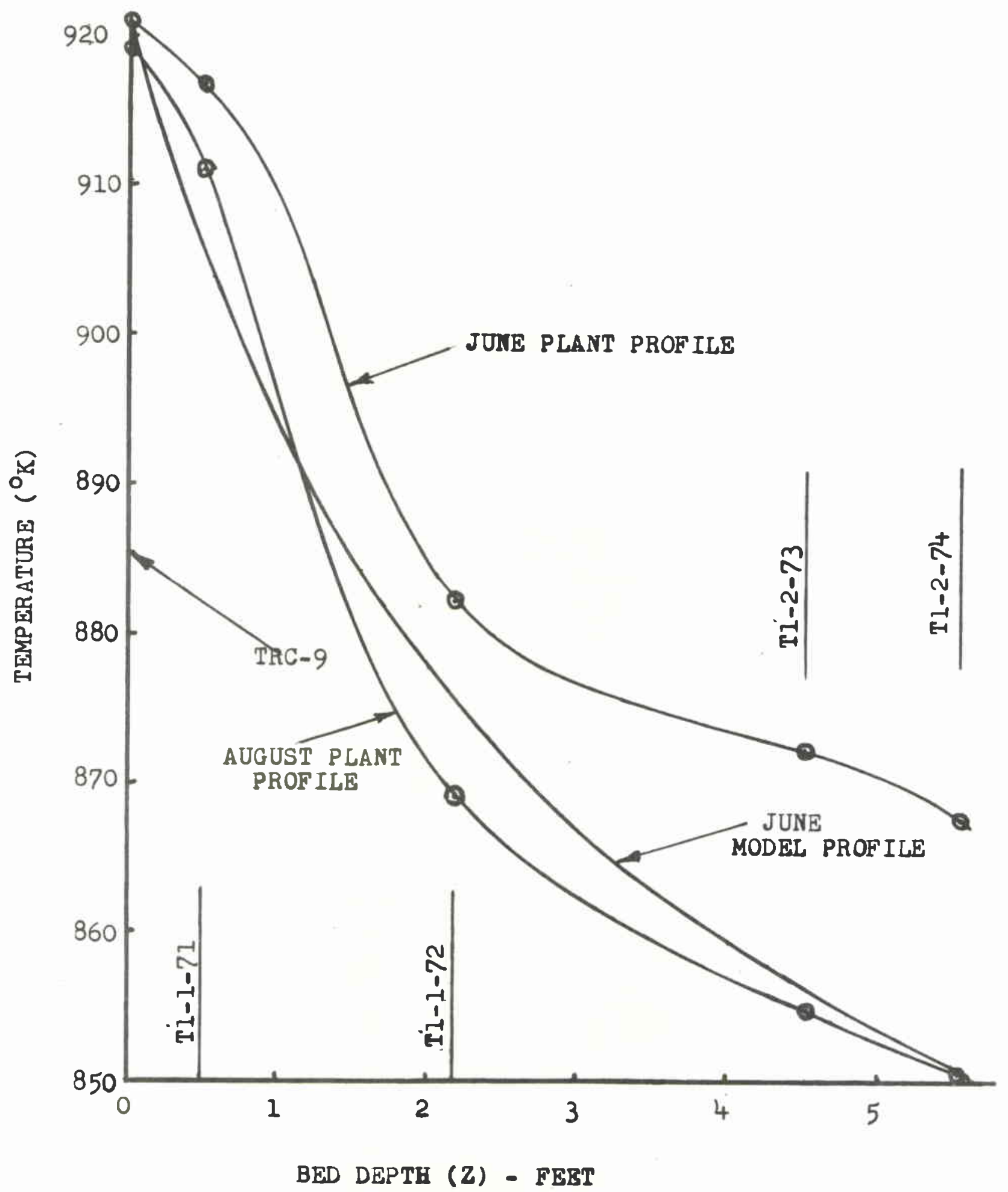




\section{PHIPERATION FOR OPTIMIZATION STUDIES}

6.1 Choice of the Cost Function

A cost function which was representative of the process chenical values only was established for the purpose of the optimization studies. It measured the gain in dollars per hour of all chenicals with an allowance for steam cost. The gain function accounts for:

(1) the overall gain in value of the aronatic chemicals

(2) the fuel value of any by-product gases

(3) the cost of stesin required.

i.e. Gain/Hr. = Gain due to Styrene + Gain due to Fuel Gases - Stean Cost - Loss due to Toluene and Benzene Table 5 lists the values of the chenicals involved in the cost function, while Appendix 8 gives calculations leading to the final gain equation.

In optimization studies conducted later, where the bed depth was a variable, the cost of the extra catalyst required was included in the cost function. The catalyst was depreciated at $\$ 0.05937 / \mathrm{Hr} . / F t$. of extra bed (i.e. greater than 5.5833 Ft.). Inclusion of this added cost had little effect on the overall gain function. 


\section{TABLE 5}

\section{VALUE OF CHEYICALS}

\begin{tabular}{|c|c|c|c|}
\hline CHEMICAL & & ALUE & SPEIECE CODE \\
\hline Ethylbenzene & .06 & $\$ / 1 b$ & C \\
\hline Styrene & .105 & $\$ / 1 \mathrm{~b}$ & A \\
\hline Toluene & .0185 & $\$ / 1 b$. & $\mathrm{E}$ \\
\hline Benzene & .037 & $\$ / I b$. & A \\
\hline Hydrogen & .03 & $\$ / 1 b$. & B \\
\hline Methane & .012 & $\$ / 1 b$. & B \\
\hline Ethylene & .011 & 专/Ib. & B \\
\hline Steam & $\begin{array}{l}.01182 \\
(T=C\end{array}$ & $\begin{array}{l}2+.0000646 \mathrm{~T} \\
\left.o_{K}\right) \$ / 1001 \mathrm{~b} .\end{array}$ & D \\
\hline
\end{tabular}

\section{References for Cost Function}

\section{Cocie}

A Canaảian Chenical Processing, April, 1966

B Based on standard heating value of $\$ .50 / 10^{6}$ B.T.U.

C Estinated in-plant value of ethylbenzene. The loss in value if it goes to by-products is approxinately equal to the gain if styrene is produced (on a pound basis).

D Estimated equation gives reasonable costs i.e. $T=800^{\circ} \mathrm{K} \quad$ cost $=\$ 0.0535 / 100 \mathrm{lb}$.

$$
T=1000^{\circ} \mathrm{K} \quad \text { cost }=\$ 0.0764 / 1001 \mathrm{~b} \text {. }
$$

Conpare to Perry Chenical Engineers Hendbook, 4th edition, 9-46, 26-28.

E Real value/2, i.e. $\$ .037 / 1$ b./2, real value taken from reference t.. Since this is an in-plant, inpure by-product strean this assumption seems reasonable. It must still be treated or used in benzene production. 


\subsection{Costs Not Included in the Cost Function}

There are numerous other costs associated with the optimization studies. It nay be found that a reactor with a longer bed nay be required, or it may be necessary to build a steam superheating furnace of larger capacity. In the case of a longer bed, a new reactor shell, supporting franework, etc., must be built and its cost must be accounted for. Loss of production from plant shutdowns due to construction must be noted. I new composition of the liquid product stream may dictate changes in the existing distillation columns. Changes to the cost function would be stepwise in nature.

Such costs, however, are fixed initial costs and these can easily be deternined after we see how nuch of a gain is possible from the chenicals involved. A considerable gain nay call for new equi ment; a slight gain may not. Any of these fixed costs can bəa depreciated on an hourly basis and then readily combined with the Gain function. If the forecast is still reasonably profitable, the proposed changes should be carried out. Operating and raintenance costs can be assumed constant for present and proposed operating conditions. Careful consideration of the limitations of the nodel should be taken. Perhaps the nain flaw is the inability of the model to account for the effect of operating temperature on the overall catalyst life. It may turn out that tivice as many shutdowins to change catalyst, which itself is relatively inexpensive, will be necessary. Thus shutiown tine will be 
COMPARISON OF RECRRSSTON FOUATION FOR GAIU WITH MODEL
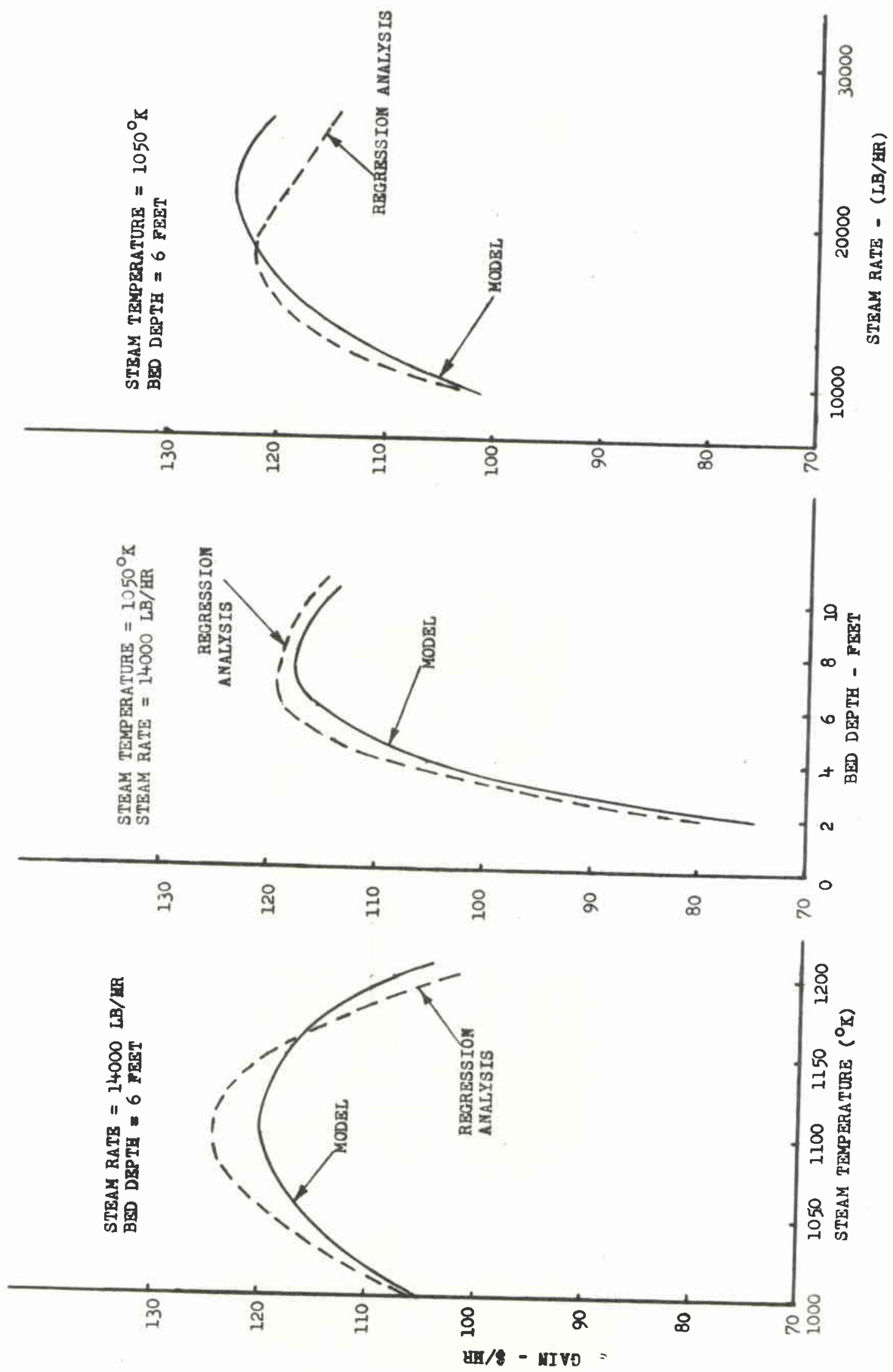


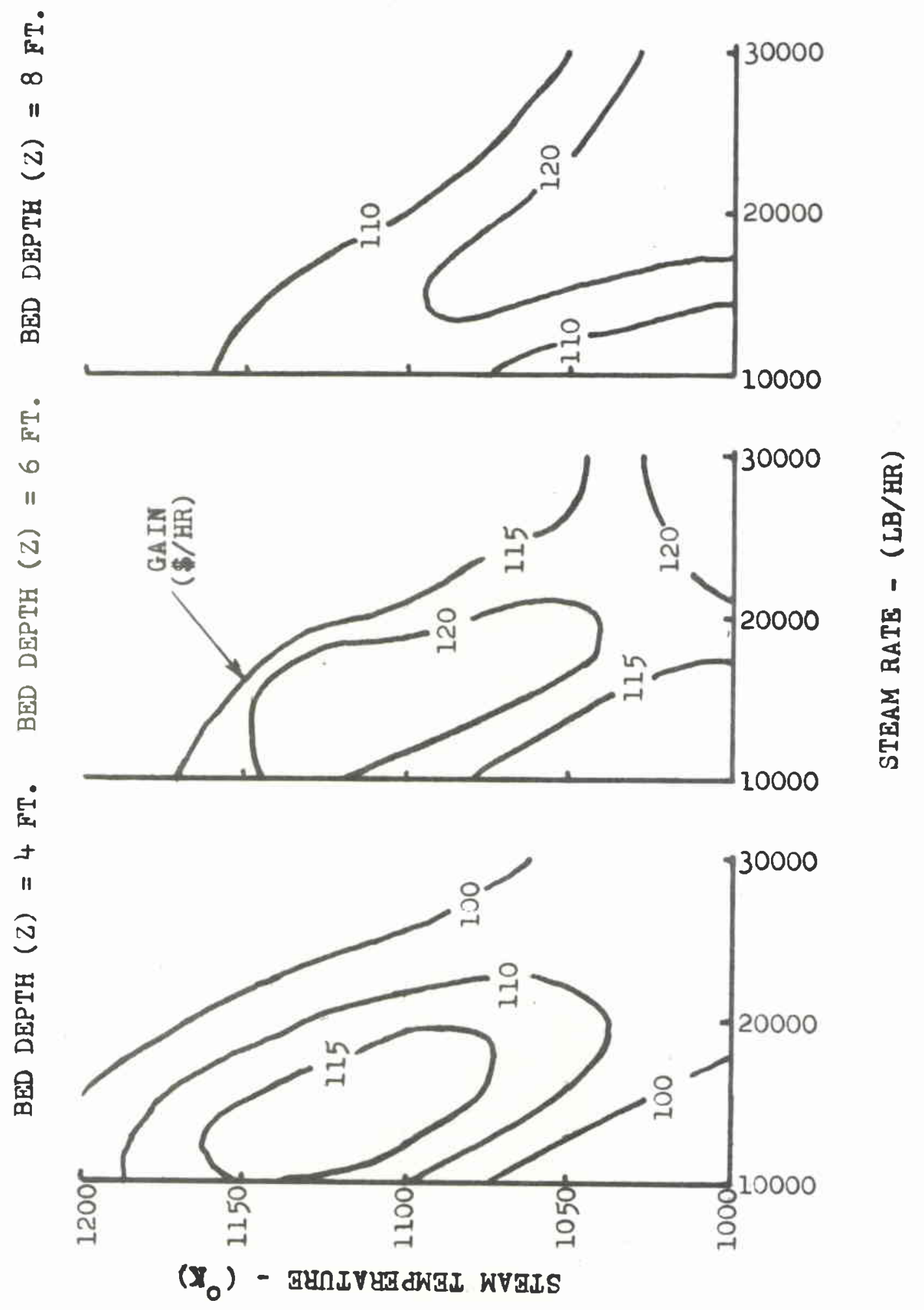


costly from the view of catalyst cost, labour, and loss of production. Nunerous variables are involved here and the problen will be discussed again in sections dealing with the optimization of various proposed situations.

\subsection{Regression Analysis studies}

An attempt was made to relate the Gain function to three major process variables for the single bed case. A $3 \times 5$ ( 125 points) factorial experiment covering the ranges indicated below was run off.

$$
\begin{aligned}
& \text { Steam Tenperature......1000 - } 1200^{\circ} \mathrm{K} \\
& \text { Steam Rate } \quad \text {......10000 - } 26000 \text { lb./hr. } \\
& \text { Bed Length } \quad \ldots \ldots .2-10 \text { feet. }
\end{aligned}
$$

The mixed feed temperature is related to the steam temperature (8.1) and it varied from $875^{\circ} \mathrm{K}$ to $1057^{\circ} \mathrm{K}$. Inlet pressure was a function of the total molar flow rate of mixed feed (3.6) and thus constituted another hidden variable. The hydrocarbon feed was always that of the April case (Table 1).

It had been hoped to use the regression equation as the response in optinization studies and in so doing, save considerable tine in calculation since the model would no longer be required. Unfortunately such an attempt failed. The regression equation is given in Appendix 9 and it is compared to the nodel in Figure 13. Figure 14 maps out the regression gain function; the response surface, although inaccurate, is similar to that generated by situation 2-ii (Appendix 13) and 
hence of interest.

The results of the multivariable searches (to be explained in 8) are given in Table 6.

\section{TABLE 6}

\section{OPTIMIZATION OF REGRESSION EOUATION}

\begin{tabular}{|c|c|c|c|c|c|c|}
\hline \multicolumn{3}{|c|}{ SEARCH BEGAN } & \multicolumn{3}{|c|}{ SEARCH ENDED } & GAIN \\
\hline $\begin{array}{l}\text { STEAM } \\
\text { TIMP } \\
O_{K}\end{array}$ & $\begin{array}{l}\text { STIAM } \\
\text { RATE } \\
\text { LB./HR. }\end{array}$ & $\begin{array}{c}Z \\
\text { FT. }\end{array}$ & $\begin{array}{l}\text { STEAM } \\
\text { TEMP. } \\
\mathrm{OK}_{K}\end{array}$ & $\begin{array}{l}\text { STEAM } \\
\text { RATE } \\
\text { LB./HR. }\end{array}$ & $\begin{array}{c}2 \\
\text { FT. }\end{array}$ & B $/ \mathrm{HR}$. \\
\hline 1100 & 10000 & 3. & 1106 & 14079 & 5.74 & 124.27 \\
\hline 1125 & 10000 & 7. & 1106 & 14079 & 5.74 & 124.28 \\
\hline 1050 & 26000 & 8. & 1000 & 30000 & 10 & 147.88 \\
\hline
\end{tabular}

Here there is a breakdo:n of the cost function as in situation 2ii-4 (Appendix 12 and 13). The search has run up against constraints in all variables.

More points are needed if the regression equation is to be representative of the nodel or the area enconpassed by the regression should be reduced. For a given plant situation, a regression expression could be useful ${ }^{13}$, but since the situation in these studies was always different, such equations would not be beneficial. More conputer tine may be required to find the regression equation than the optimum.

\subsection{Time Studies}

The rate of change of temperature with oistance $(\Delta \mathrm{T} / \Delta \mathrm{Z})$ which was arrived at fron the energy balance (3.5) has been 
handiled outside the integration, i.e. the tenperature over each integration step has been considered to be constant. This sinplification allows a saving of about $15 \%$ in computation time over a similar case with the temperature insiae the integration. The question arises - if the temperature'is included in the integration, would it be possible to reduce the number of steps so that there is an overall saving in time? Runs of both types were made at various step sizes. The fpril case was used and comparisons are offered in Table 7.

No advantage was found when the temperature was included in the integration. Convergence to steady values came quicker, but in approximately the sane number of steps so that computation tiae renained greater.

\section{TABLE ?}

TEFPRRETURE OUTSIDE VS. TPIPERITUED INS IDE THE INTEGRATION

(A) TEVPRRETURE OUTSIDE

\begin{tabular}{|c|c|c|c|c|c|}
\hline $\begin{array}{l}\text { NUMBER } \\
\text { OF STEPS }\end{array}$ & $\begin{array}{l}\text { OUTLET } \\
\text { TENP. }{ }_{K}\end{array}$ & $\begin{array}{l}\text { ETHYLBENZENE } \\
\text { LB./HR. }\end{array}$ & $\begin{array}{l}\text { STYRENE } \\
\text { LB./HR. }\end{array}$ & $\begin{array}{l}\text { TULUENE } \\
\text { LB./FR. }\end{array}$ & $\begin{array}{l}\text { BENZINE } \\
\text { LB./HR. }\end{array}$ \\
\hline $\begin{array}{l}50 \\
40 \\
35 * \\
30 *\end{array}$ & $\begin{array}{l}850.75 \\
350.71 \\
851.32 \\
85+.09\end{array}$ & $\begin{array}{l}4550.58 \\
4547.42 \\
4577.32 \\
4705.16\end{array}$ & $\begin{array}{l}3573.64 \\
3574.99 \\
3559.94 \\
3466.17\end{array}$ & $\begin{array}{l}412.02 \\
412.54 \\
408.82 \\
407.31\end{array}$ & $\begin{array}{l}257.53 \\
258.40 \\
250.35 \\
228.40\end{array}$ \\
\hline (B) I'EIMP & \multicolumn{5}{|c|}{ ERATURE INSIDE } \\
\hline $\begin{array}{l}\text { NUMBER } \\
\text { OF STEPS } \\
\end{array}$ & \begin{tabular}{l|} 
OUTLET \\
TEMP. K
\end{tabular} & $\begin{array}{l}\text { ETHYLBENZEINE } \\
\text { LB./HR. }\end{array}$ & $\begin{array}{l}\text { STYREITE } \\
\mathrm{LB} . / \mathrm{HR} \text {. }\end{array}$ & $\begin{array}{l}\text { TOLUESE } \\
\text { LB./HP. }\end{array}$ & $\begin{array}{l}\text { BE NZENE } \\
\mathrm{LB} \text {. } / \mathrm{HR} \text {. }\end{array}$ \\
\hline $\begin{array}{l}50 \\
40 \\
30\end{array}$ & $\begin{array}{r}851.06 \\
851.06 \\
\text { mod }\end{array}$ & $\begin{array}{l}4567.18 \\
4567.02 \\
\text { breals down }\end{array}$ & $\begin{array}{r}3567.18 \\
3567.28 \\
\text { mpletely }\end{array}$ & $\begin{array}{l}409.28 \\
409.31\end{array}$ & $\begin{array}{l}252.49 \\
252.51\end{array}$ \\
\hline
\end{tabular}

* Reaction 16 is slightly unstable during intial integration
steps. 
Other integration techniques could not be tried since it was necessary to go on to the optinization studies. Thirdorder Runge-iutta, or predictor-corrector methods might have allowed a saving in computation tine with the same accuracy. 


\section{MITHOD OP OPTIMIZATION}

\subsection{The General Method}

A multivariable search technique, that of Rosenbrock ${ }^{4}$, was chosen to seex out the optimum operating conditions of proposed plant situations. The method is advantageous because it not only finds the optinum conditions of well-behaved response surfaces, but also is able to follow sharply defined ridges quickly and efficiently。

Basically, the programme employs the GRAM-SCHI:DT Orthogonalization ${ }^{4}$ and 14 to adjust the direction of the search to follow the ridge. This is, in reality, a flexible method of steepest ascent15. Initially, for convenience, the directions of search are parallel and perpendicular to the coordinate systen. Each variable is perturbed in turn and a corresponding response is obtained.

An accelerator is used after a success (higher value of the response if seeking a maximum) has been found in one direction. The step length in that direction becomes $\alpha(\alpha>1)$ times the former step length on the next testing of that variable. Similarly, upon recording a failure, the search returns to the beginning of the step, carries on with the other variables, and on returning to the variable registering the failure, it nultiplies the forner failure step length by $\beta(-1<\beta<0)$, and so searches in the opposite direction for that variable. 
When at least one failure has been found for each variable, a stafe has been conpleted, and the search halts. Then, using the initial and final base-points of the stage just completed, it evaluates now search directions by the orthogonalization process. When successive responses differ by a preset value a predetermined number of times, the entire search ends, hopefully at the optimum.

Figure 15 shows the beginning of a Rosenbrock search over two variables, $\mathrm{X}$ and $\mathrm{Y}$, whose response is a profit which we seek to naximize.

At point A, a response of $\$ 1.60$ is obtained. When we perturb $\mathrm{X}$ by $I$ unit (i.e. $\phi=1$ ), the new higher response ( $\$ 1.72$ ) becomes the temporary base point. After a similar success in $Y$, we edvance $X$ by $\alpha$ tines $\phi$ (here $\alpha \times 1$ or $\alpha$ ), anỏ again register a success (\$2.70). On continuing: similar successes in $Y$ and $X$, bring us to a response of $\$ 3.0$.. When the change in $Y$ is again accelerated, since the last change in $Y$ had been successful, we find a profit of only $\$ 2.62$ and so we have a failure for $Y$. The search returns to the point of the last success (\$3.01) and perturbs X by $\alpha \times\left(\alpha^{2}\right.$ ) or $\alpha^{3}$ to a response of $\$ 3.03$. Since the last change in $Y$ resulted in a failure we now change $Y$ by $\beta\left(\alpha^{2}\right)$, in the opposite direction to the previous $Y$ movement. Fron point 3 , we get a failure (\$1.21) by advancing $X$ by $\alpha^{4}$ and since se now have at least one failure per variable, we cone to the end of the first stage (point 3 ). The next search begins in directions parallel and 
perpendicular to the vector joining $A$ and $B$ (determined by orthogonalization), the initial and final base points of the first stage. The first two probes result in failures, i. e. $\$ 3.10$ and $\$ 3.08$, and so, we search in the opposite direction (due to registering successive failures for all variables on initial chanês). A similar pattern brings us to point $C$ and the next directions of search parallel and perpendicular to the line BC. The search procedes in such stages toward the combination of $X$ and $Y$ yielding the maximun profit.

Rosenbrock's programme has been used for various purposes in this report. In order to find the frequency factors, an initial set $\left(A_{i}\right.$ of $\operatorname{EXP}\left(-\Delta \mathrm{E}_{i} / \mathrm{RT}+A_{i}\right)$ ) was chosen and a search was conducted on these values. The response for these searches has already been discussed (5.1).

Later, in optinization searches, variables such as the stean temperature (i.e. this is proportional to the mixed feed temperature), steam rate, bed length, etc., were searched. The effect of changes, carried out by the search proframme, on the Gain response (6.1) was of interest here. Naturally, those values of variabies giving the maximum Gain represented the optimum.

This search nethod has limitations. The degree of acceleration and deceleration (i.e. $\alpha$ and $\beta$ ), is subject to human choice. Certain values of $\alpha$ and $\beta$ may work well for one situation and poorly for another. In most cases, an $\alpha=2$. and $B=-.5$ were found to be adequate. The choice of the initial 


\section{ILLUSTRATION ROSENBROCK SEARCH}

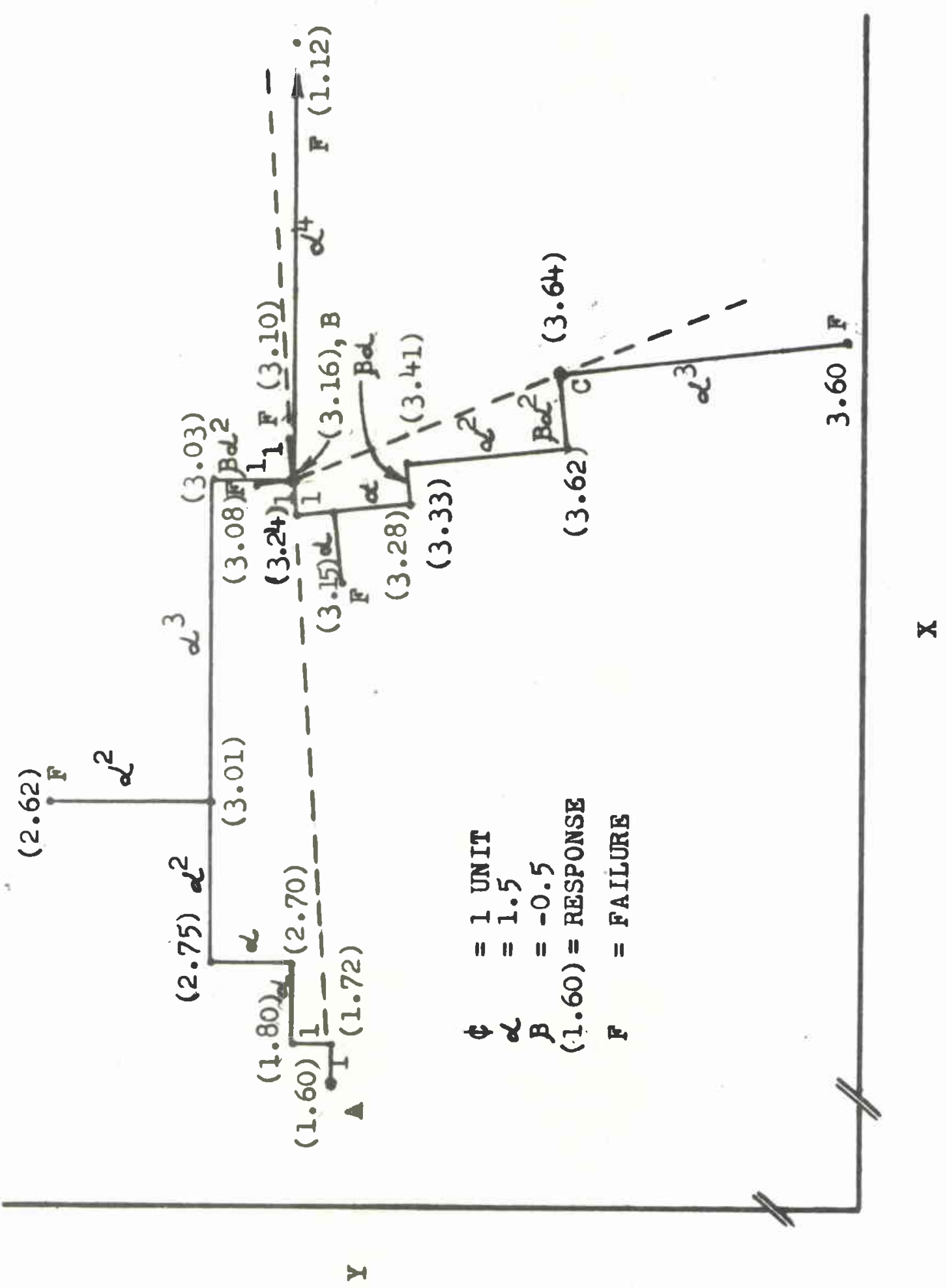


step ( $\$$ ) is inportant too. Perhaps as one approaches the optimum, the initial step should be reduced after each stage (i.e. $\$=0.95 \times \$$ ). Another nethod of reduction nay have proved more successful.

In order to save tine and facilitate prograraming, the variables were scaled so that all were of the sane order of magnitude. An example of scaling is shown below:

\begin{tabular}{l|l|l} 
VARIABLE & MODEL RAIGIS & SEARCH SCALED RATGE \\
\hline Steam tenperature & $1000-1200^{\circ} \mathrm{K}$ & $1000-1200$ \\
Stean flow rate & $0-30000 \mathrm{Lb} \cdot / \mathrm{Hr}$. & $0-3000$ \\
Bed length & $0-10 \mathrm{Ft}$. & $0-1000$
\end{tabular}

Thus a common $\phi, \alpha$, and $\beta$ could be used for all variables of a search.

Highlights of the programme are illustrated in a logic flow chart in Appendix 10. An application of the technique is given in Appendix 11 where a 2-bed, 5 variable situation is optimized.

\subsection{Handling of Constraints}

Only linear constraints are found in these optinization studies and although the methods used to handle them are not written in general forn, they can be readily adjusted to deal with non-linear constraints. Two types of constraints were met and these were dealt with in different ways. A constraint of the type $\mathrm{X}_{1}+\mathrm{X}_{2} \leq \mathrm{H}$ was handled by the "mirror image" nethod described below while constraints of the form $\mathrm{X} \leq$ if were dealt 
with the "high failure" technique. It was relatively easy to integrate both types of constraints into the search programme. The High Failure Method For $X \leq 1$ - At certain times a constraint of this type was placed on the steam temperature, bed length, inlet pressure and steam rate. Whenever the search yielded a value of the variable in question greater than that permitted (i.e. M) the response was set to a very high value (when seeking a minimum) and the model was bypassed. A failure was recorded and the search would continue as described in 7.1 (Figure 16́.). It was necessary to improvise the search programme here because on sone occasions (Figure 163) the search would come to a quick halt. When the directions of search were nade parallel and perpendicular to the original axes, and so likewise to the constraint, the search could proceed along the constraint very efficiently. Successive fálures in all variables would trigger this rotation back to the original search directions.

The Mirror Inage Nethod $\left(\mathrm{x}_{1}+\mathrm{x}_{2} \leq \mathrm{M}\right)$ - Constraints of the type $x_{1}+x_{2} \leq M$ were found when the total available steam rate (also total bed depth) to two beds was linited and an appropriate $\mathrm{X}_{1}, \mathrm{X}_{2}$ distribution was sought. The search proceeds normally until the variables $x_{1}$ and $x_{2}$, together, exceed their constraint (M). Instead of recording the response of this situation, new values of $\dot{X}_{1}$ and $x_{2}$ are found by taking their nirror inage about the constraint. All other variables remain as they were 
and the response is then recorded (Figure $17 \hat{A}$ ). The search continues with the forner values of $x_{1}$ and $x_{2}$. A very searchable response surface is generated.

The method has drawbacks in situations where the response contours are almost parallel to constraints (Figure 17B), or where the contours are wavy (Figure 17C), or where they are convex toward the constraint (Figure 17D). It must be mentioned that difficulties such as these exist in any event, nirror image or not. The situation where the optimum lies within the constrained region is easily handled by the technique since the search on the variables nay either be direct or indirect with reflection into the permissible area (Figure 17E).

A good knowledge of the nature of the response surface is helpful. Verification of whether or not the optimum has been reached may be obtained by running nunerous searches, each beginning at an extremity of the variables so that most of the region has been traversed.

The high failure method was not used for handing $X_{1}+X_{2} \leq M$ constraints since it was not considered practical to calculate directions of search along these constraints. In essence, it was easier to incorporate the airror image treatnent into the progranmes. 


\section{CONSTRAINTS - HIGH FAILURES FOR $\mathrm{X} \leq \mathrm{M}$}

\section{EICURE I6A - HIGH FAILURE METHOD}

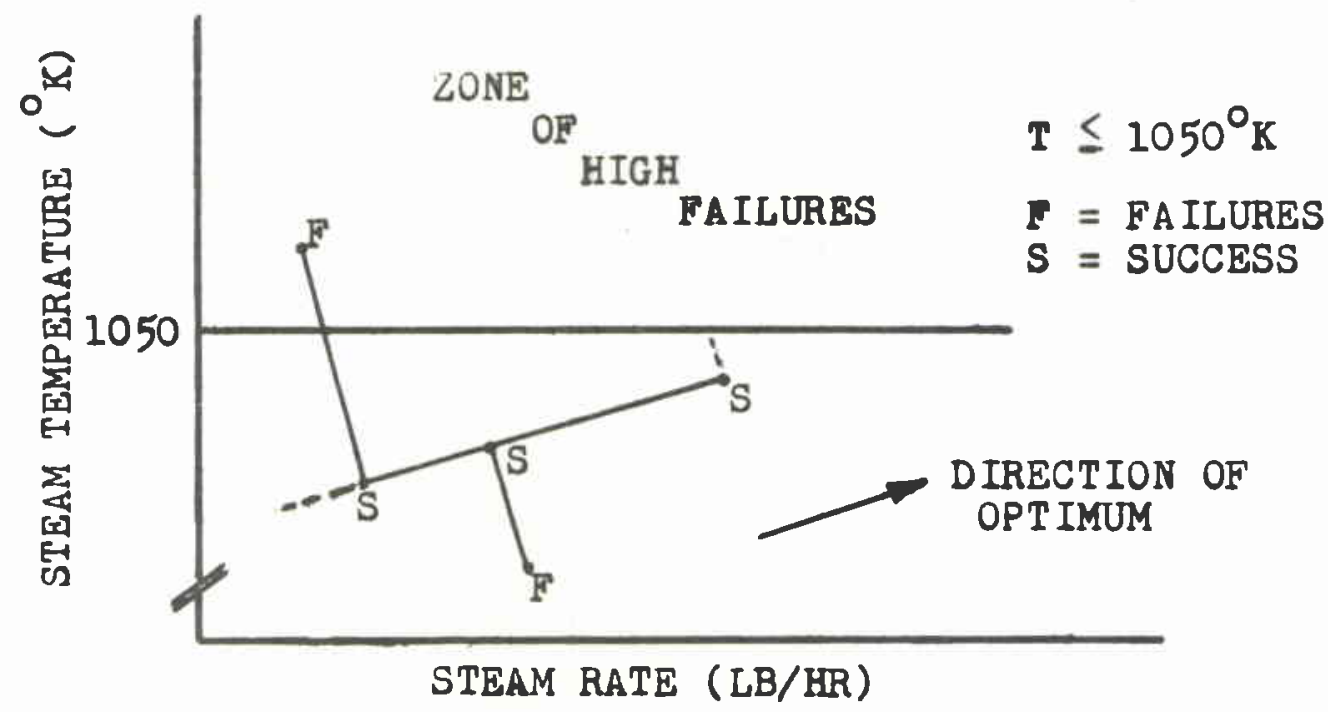

FIGURE 16B - IMPROVISATION TO ROSENBROCK FOR HIGH FAILURE METHOD

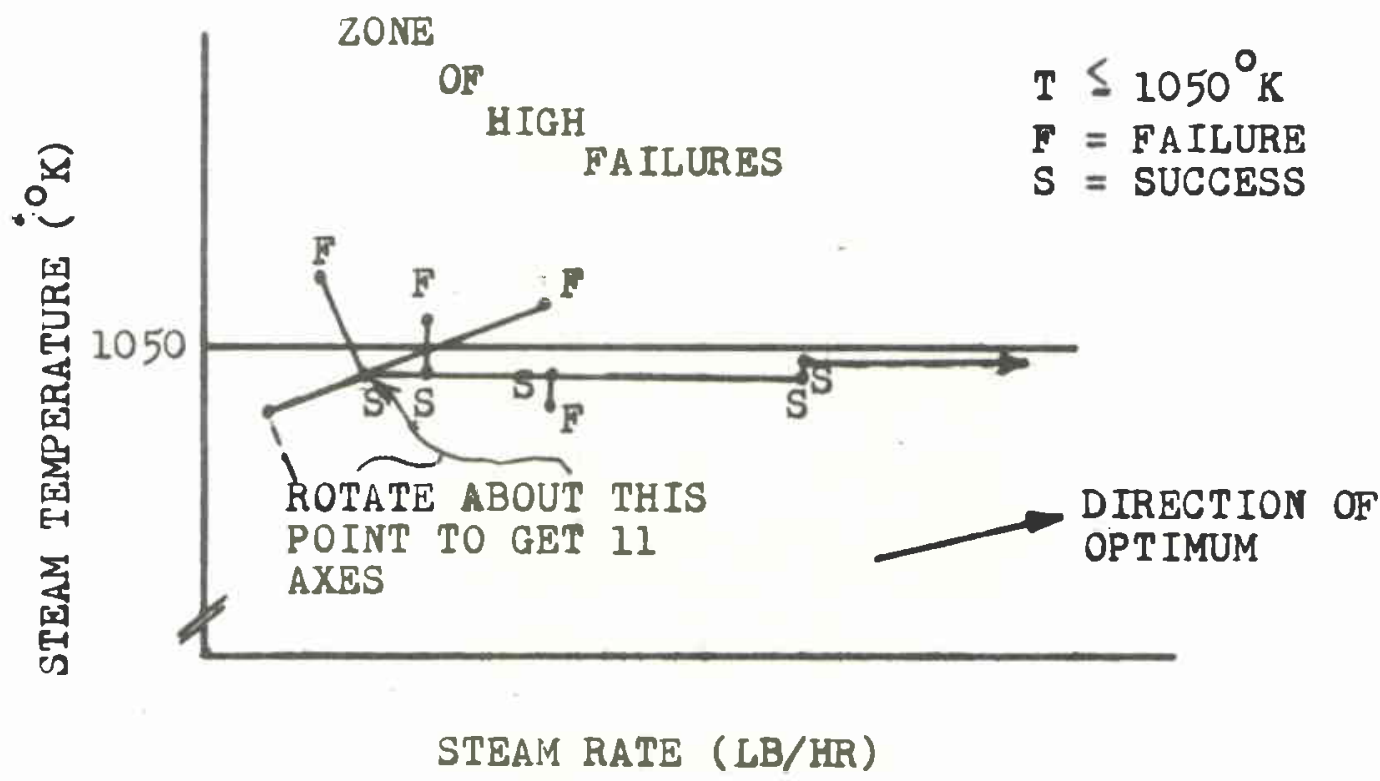




\section{CONSTRAINTS - MIRROR IMAGE FOR X1 + X2 $\leq M$}

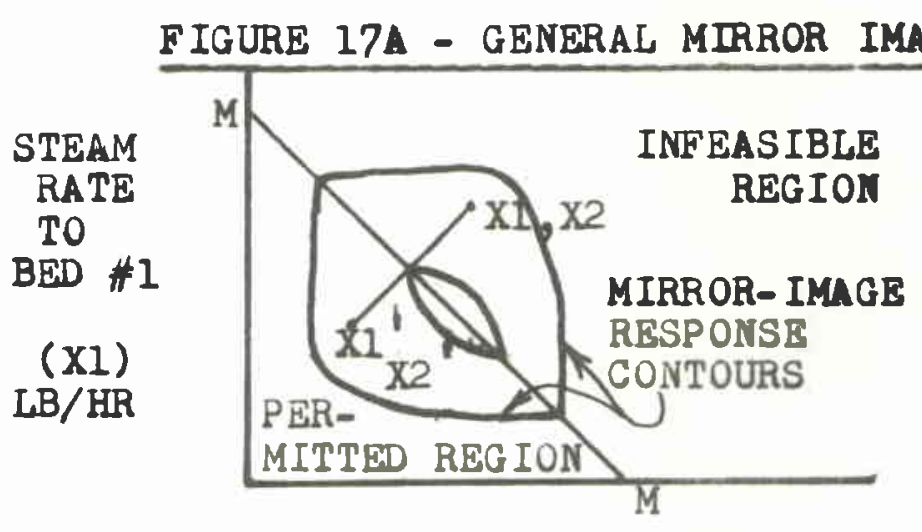

STEAM RATE TO BED \#2

(X2) $[\mathrm{B} / \mathrm{HR}$

\section{$x_{1}+x_{2} \leq M$ \\ COMMENTS}

(1) $X 1, X 2$ OF SEARCA BECOME $X 1^{\prime}, X^{\prime}$ IN THE RESPONSE FUNCTION

(2) RESPONSES WITH X1, X2 AND XI', X2' ARE THE SAME; HENCE SEARCH TENDS TO CONSTRA INT.

FIGURE 17B - RESPONSE CONTOURS APPROXIMATELY

PARALLEL TO CONSTRAINT

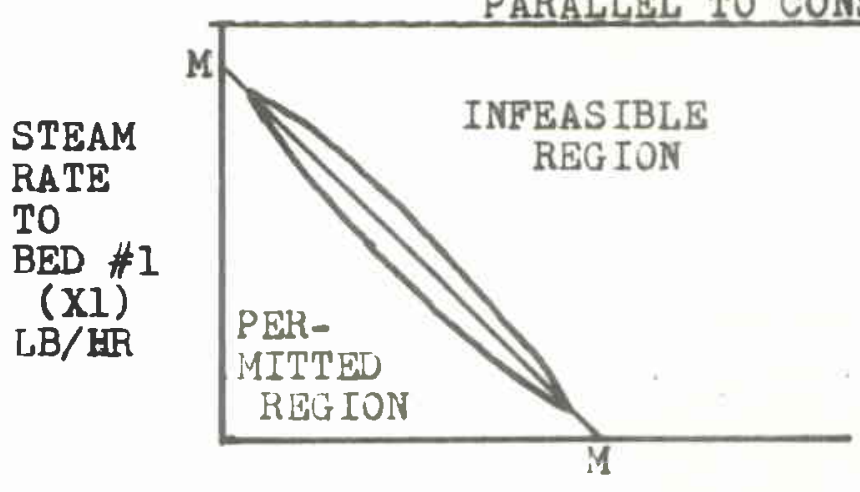

STEKM RATE TO BED \#2 (X2) LB/HR

\section{COMMEITS}

(1) A VERY STEEP RIDGE IS CREATED AND IT WILL TAKE A LONG TIME TO ARRIVE AT THE OPTIMUM

(2) IF THE CONTOURS ARE PARALLEL TO THE CONSTRAIYT, THE SITUATION IS DEGENERATE

RIGURE 12C - WAVY BESPONSE CONTOURS ALONG CONSTRAINT

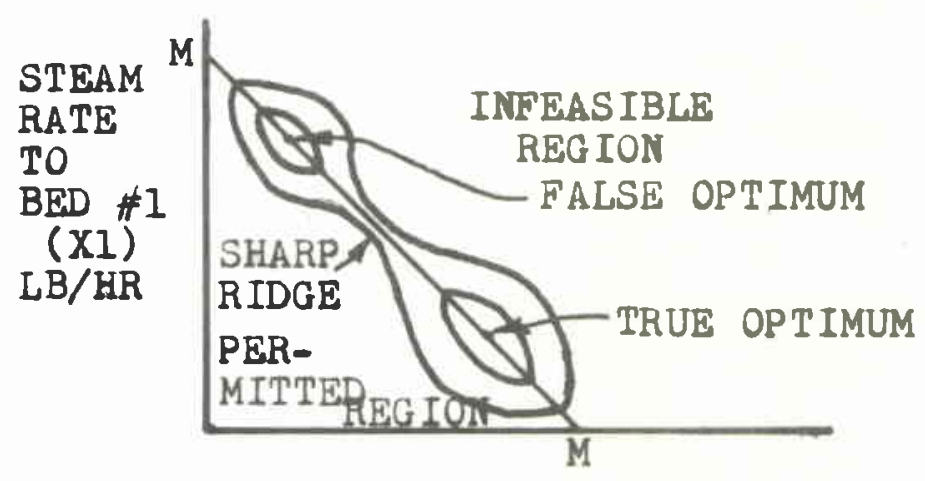

STEAM RATE TO BED \#2 (X2) LB/HR
COMMEITS

(1) CAN ONLY FIND THE TRUE OPTIMUM BY RUNNING A SERIES OF SEARCHES BEGINKING AT DIFFERENT POINTS

(2) THE SEARCH MAY HAVE DIFFICULTY AT SHARP RIDGES 


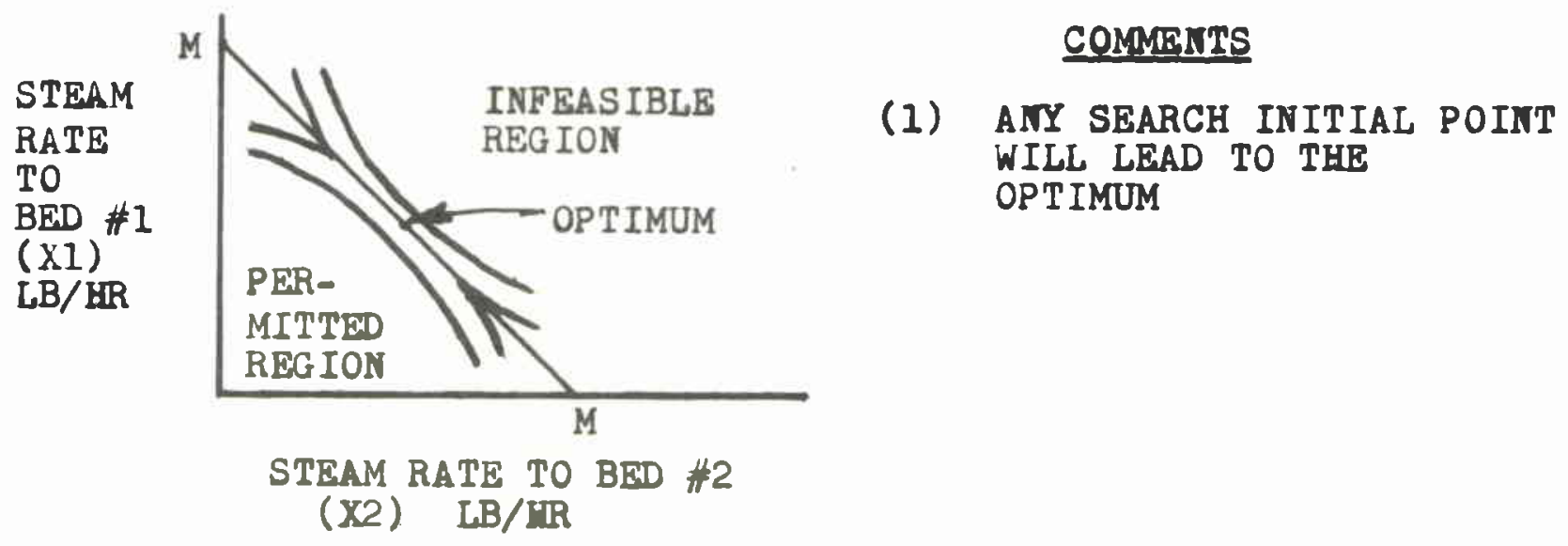

FIGURE 17E - OPT IMUM LIES IMSIDE THE CONSTRAINT

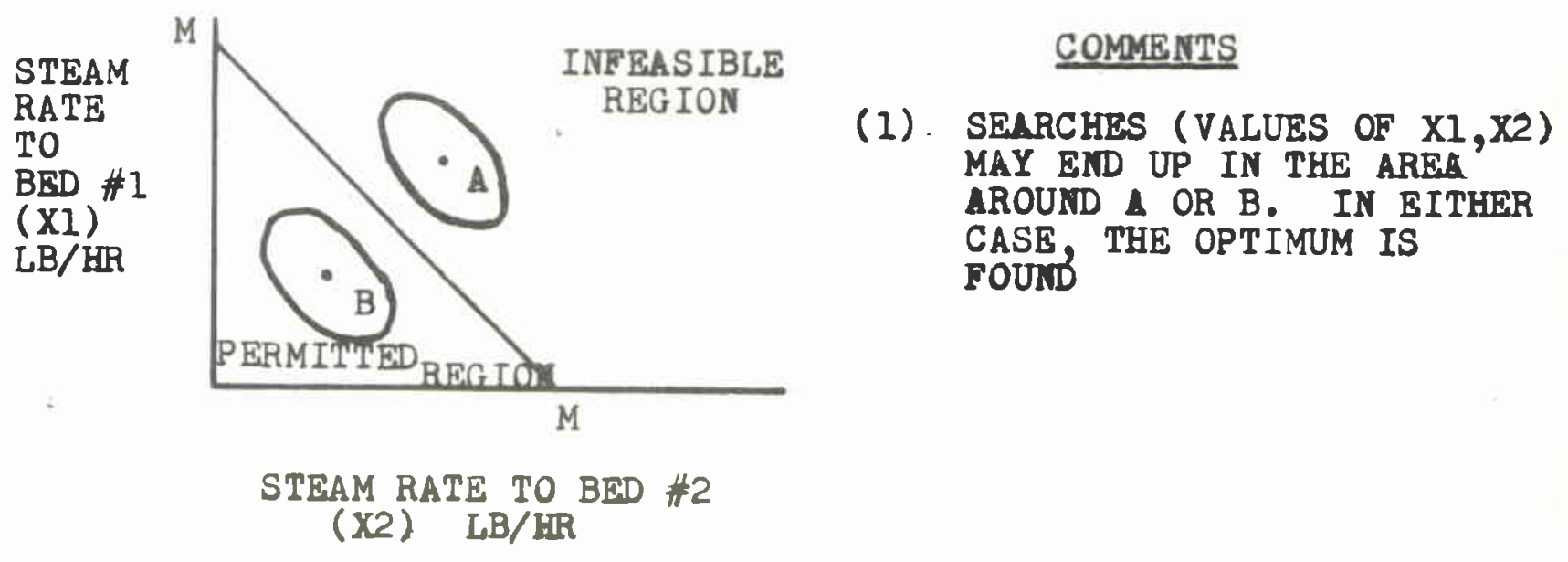




\section{OPTIMIZATIUT AND DESIGI STUDIES}

Mild and extreme searches over process variables for both the single bed (8.1) and the double bed reactor systens (8.2) are carried out below. All trends, behavior of the Gain function with changes in variables, etc., have been noted and the knowledge obtained has been applied to the more practical problen of changing the present single bed into a double bed without requiring major changes in existing equipnent ( 9.2 and 8.3).

\subsection{Design and Optimization of a Single Bed}

8.1.1 Ains, variables and constraints

The model of the fpril plant situation will be extrapolated for the najor process variables (i.e. mixed feed temperature, steam flow rate and bed length). Each combination of variables would be run under two sets of constraints. The actual plant limitations allowing a naximum stean rate of $180001 \mathrm{~b} . / \mathrm{hr}$. and a maximum steam temperature of $1050^{\circ} \mathrm{K}$ would be tested. These values would becone $300001 \mathrm{~b} . / \mathrm{hr}$. and $1200^{\circ} \mathrm{K}$ respectively in more severe extrapolations. The suspected optimum operating condition for the single bed is thought to lie at a stean to hydrocarbon ratio of $2.61 \mathrm{~b} . / 1 \mathrm{lb} .^{5}$, i.e. at about 23400 lbs. steam/hr. for the April hydrocarbon feed rate.

Since the linitation on temperature is expressed in terms of the steam temperature, it was decided to use this 
quantity as a variable instead of the mixed feed tenperature. $20001 \% . / \mathrm{hr}$. of the total steen flow (April case) is mixed with the pure hydrocarbon feed stream for preliminary heating (we shall refer to this resulting stream as the HS strean). The renaining steam $(16000 \mathrm{lb} . / \mathrm{hr}$.$) is mixed with the HS stream$ at the reactor entrance. Although the states of the $2000 \mathrm{lb} / \mathrm{hr}$. stean and the $16000 \mathrm{lb} / \mathrm{hr}$. superheated steam are different, it was assumed that both streams were at the temperature of the stearn leaving the superheater (Figure 2). It was calculated that in order to have a mixed feed temperature of $922.590^{\mathrm{K}}$. for a steam (exit superheater) temperature of $1027.7^{\circ} \mathrm{K}$, the HS stream must be at $807^{\circ}$. This overall assumption was necessary since nothin: was known of the pure feed condition prior to rixing with the $20001 \mathrm{~b} / \mathrm{hr}$. stean. In all runs for both the single and double beds, it was assuned that the temperature was $807^{\circ} \mathrm{K}$, no ratter what the temperature of the superheated stean was. To this strean is added the renaining stean and the mixed feed temperature results. Figure 18 shows the relationship between the steam temperature, mixed feed temperature and steam rate.

The inlet pressure for a single bed remained a function of the total nolar hourly flow rate (3.5). An upper limit of 10 feet was placed on the bed length.

\subsubsection{Reactor_situations studied}

This section illustrates the various combinations of 
variables and constraints studied for single and double bed reactors. Each such combination is classified by a situation number. Complete results of each optimization are found in Appendices 12 and 13, and these may be related to this section by the situation nuibers. Appendix 12 gives the values of the process variables at the beginning and the end of a search, along with the corresponding optimun value of the Gain function (嘞/Hr.). Appendix 13 shows more complete results at the optimum condition for each situation. Duplicate runs are represented by case numbers.

For convenience, all combinations of variables and constraints for both single and double beds are included together. These situations are illustrated below.

\section{Legend: For Reactor Situations Studied}

\begin{tabular}{ll}
$\begin{array}{l}\text { QUiITITY } \\
\text { NAME }\end{array}$ & \multicolumn{1}{c}{ DESCRIPTION OF VARIA3LE } \\
T & Steam temperature ( $\left.\mathrm{O}_{\mathrm{K}}\right)$ \\
S.R. & Stean flow rate, single bed ( Lb./ $\mathrm{Hr})$. \\
Z & Bed length, sing le bed (Ft.) \\
P & Inlet pressure (Atmos.) \\
S.R.1 & Stean flow rate to lst bed ( Lb./Hr.) \\
S.R.2 & Steam flow rate to 2nd bed ( Lb./Hr.) \\
Z1 & Bed length, 1st bed (Ft.) \\
Z2 & Bed length, 2nd bed (Ft.)
\end{tabular}




\subsubsection{Reactor situation studies}

(1) Single bed - 2 variables

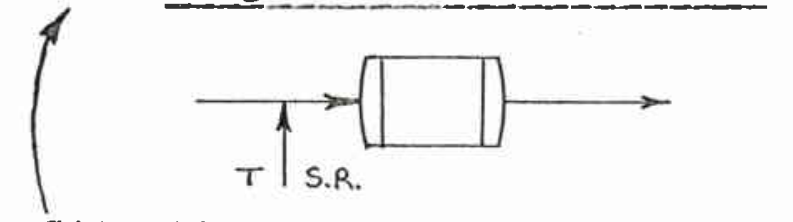

Situation

Nuinber

COINTREINTS

T

(i) $\leq 1050$

(ii) $\leq 1200$

(2) Single bed $=3$ variables

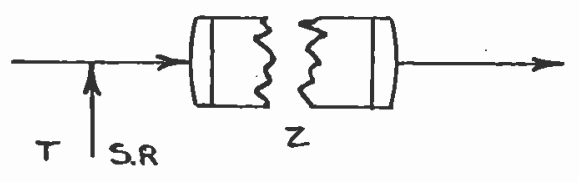

CONSTREIITS

$\mathrm{T}$

S.R.

(i) $\leq 1050 \leq 18000 \leq 10$

(ii) $\leq 1200 \leq 30000 \leq 10$

(3) Double Bed - 3 variablables

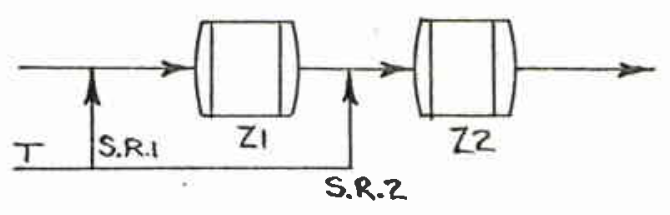

COISTREIITSS

(i) $\mathrm{T} \quad($ S.R.I + S.R.2) $\leq$

(i) $\leq 1050$

18000

(ii) $\leq 1200$

(iii) $\leq 1200$

30000

13000
FIXED PARAMETERS

$Z=5.5833 \mathrm{Ft}$.

VARIABLTS

$\mathrm{T}$

S.R.

$P=a+b\left(S . R_{0}\right) *(\sec 3.5)$
FIXED PARA:TITERS

None

VARIABIES

$\mathrm{T}$

S.R.

$\stackrel{Z}{P}=a+b\left(S \cdot R_{0}\right)^{*}$

\section{FIXED PAEA:ETERS}

$$
\begin{aligned}
\mathrm{P}_{1}= & 2.37 \text { atinos. } \\
\mathrm{Z}_{1}= & \mathrm{Z}_{2}=2.79165 \mathrm{Ft} . \\
= & \text { one-half present } \\
& \text { single bed length }
\end{aligned}
$$

VAFIA BIES

$\mathrm{T}$

S.R.I

S.R.2

* Note - The inlet pressure $(P)$, unless constant is an indirect variable since it is a function of $\mathrm{S} . \mathrm{R}$., the stean flow rate. 
(4) Double bed - 5 variables

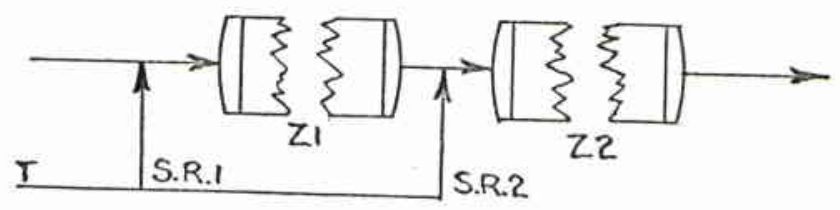

COISTRAIITS

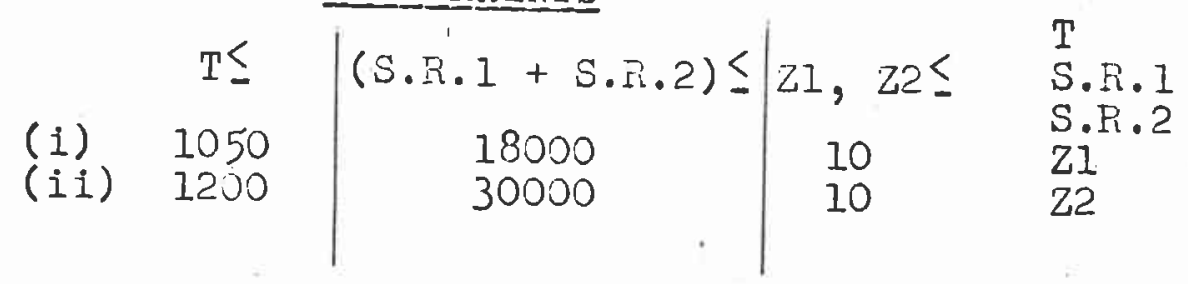

\section{FIXED PAIAIETEIRS}

$P=2.37$

VARIABLES

(5) Double $\underline{\text { Sed }}=\underline{6}$ variables

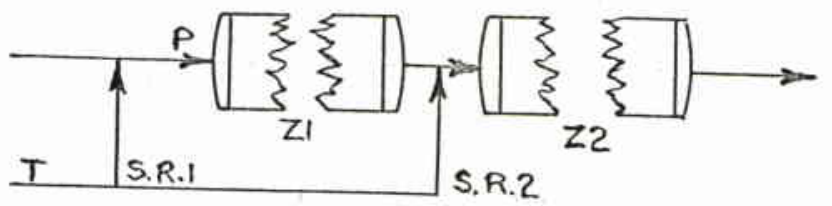

FIXED PARAMETIRS

None

VAR IABLES

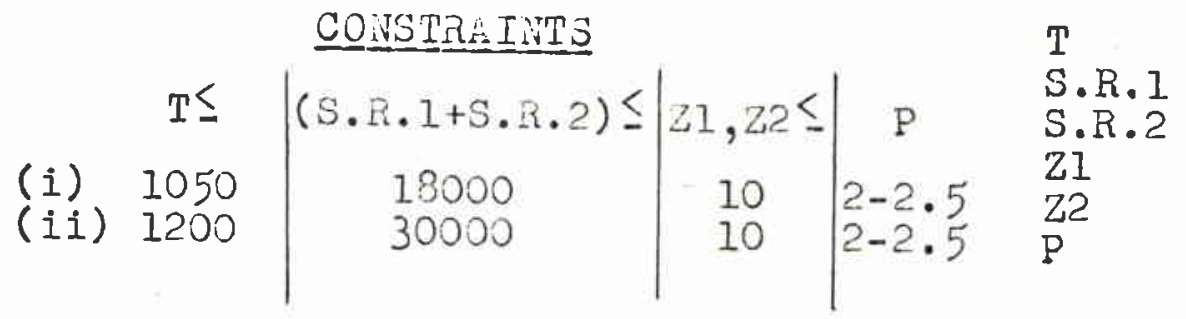

(6) Single bed converted to 2 beds; 5 variables

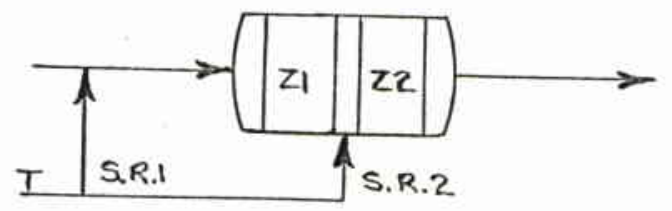

CONSTRA INTS

(i) 1050

(ii) 1027.7

(iii) 1200

(iv) 1050

(v) 1200

(vi) 1027.7
$T \leq$ (S.R.I+S.F.2) $\leq$

18000

18000

30000

30000

30000
18000
FIXED PARAMETERS

$P=2.37$

VARIABLES

$\mathrm{T}$

S.R.I

S.R.2

Z1 
(7) Single bed $=$ l variable

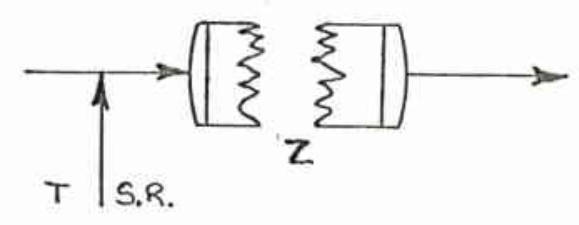

COISTREINTS

$$
z \leq
$$

FIXED PARAMIEERS

$P=2.37$

S.R. $=18000$

$\mathrm{T}=1027.7$

VARIABLE

\subsubsection{Discussion of Pesults}

A single reactor of the type investigated, operates at a Gain of $\$ 117.31 / \mathrm{Hr}$. (Appendix 12, Standard April Case): Polymer operates three of these. A search (situation l,i) with the stean tenperature varying up to $1050^{\circ} \mathrm{K}$ and the stean rate permitted to reach $180001 \mathrm{~b} . / \mathrm{hr}$. at a fixed bed depth of 5.5833 feet showed that each reactor could yield $\$ 120.45$. This is a rather insignificant gain, especially so when one considers that the catalyst may age quicker aue to the increased coke caused by higher nixed feed temperature (M.F.T.). As stean temperature rose from $1027.7^{\circ} \mathrm{K}$ (April case) to $1049.98^{\circ} \mathrm{K}$, the M.F.T. moved from $922.59^{\circ} \mathrm{K}$ to $934.76^{\circ} \mathrm{K}$ (Fizure 18).

When constraints were lifted (situation 1,ii), it was found that the optimuin values of the steam temperature and flow rate were $1062.03^{\circ} \mathrm{K}$ and $221401 \mathrm{~b} . / \mathrm{hr}$. respectively, with a

* Whenever situation numbers are noted, please refer to Appendix 12, then 13 if nore infornation is desired. 
FIGURE 18

RELATIONSHIP BETWEEN MIXED FEED TEMPERATURE, STEAM TEMPERATURE,_AND_STEAM RATE

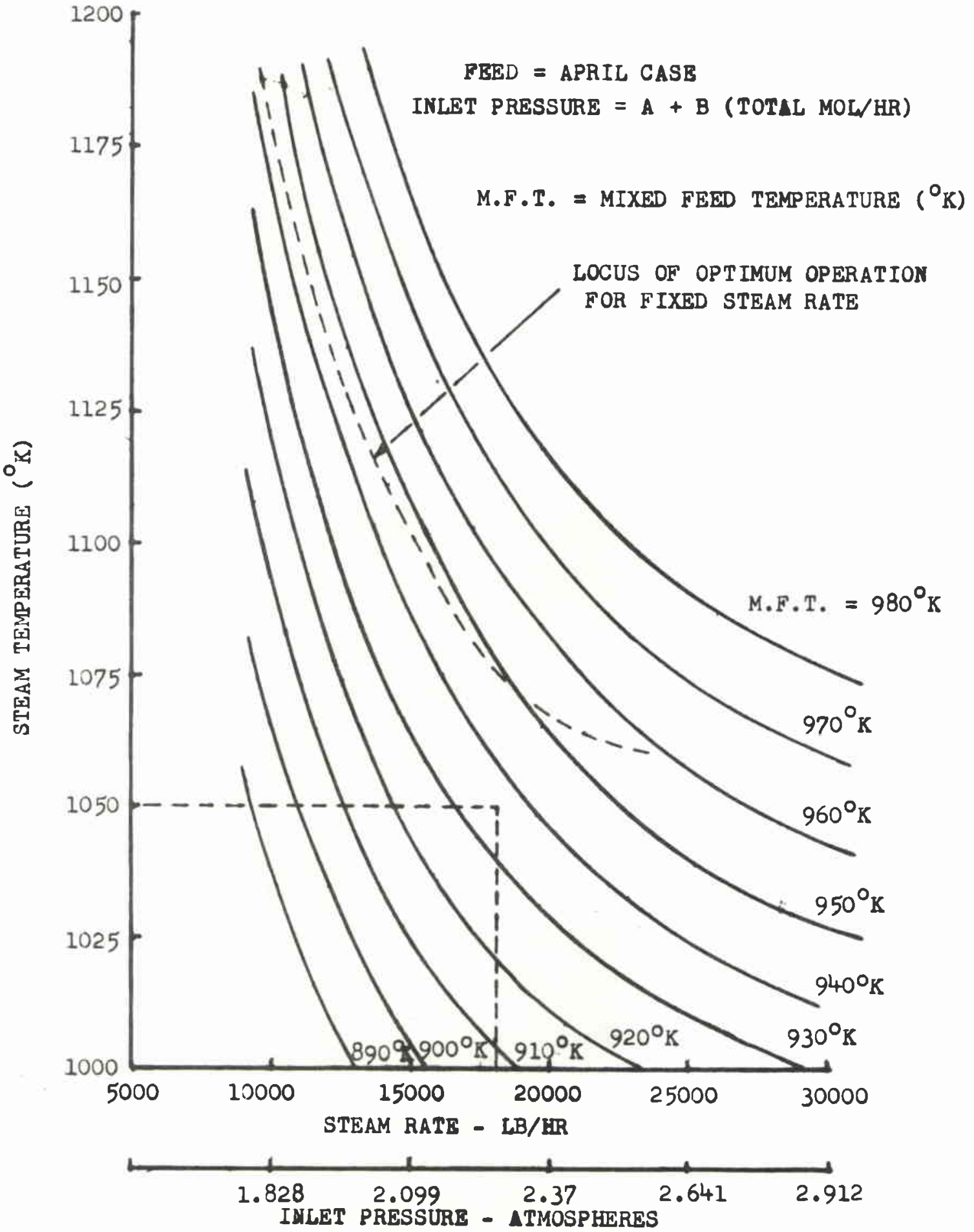


corresponding Gain of $\$ 123.10$ per hour. Although the mixed feed temperature of $956^{\circ} \mathrm{K}$ indicates more severe carbon buildup, it is thought that the higher steam rate would tend to cancel out the effect of higher temperature. The steam to hydrocarbon ratio is about $2.46 \mathrm{Lb} . / \mathrm{Lb}$. as compared to the present $2.0 \mathrm{Lb} / \mathrm{Lb}$. This finding agrees well with the value of $2.6 \mathrm{Lb} / \mathrm{Lb}$. cited by Boundy and Boyer ${ }^{5}$ but it must be noted that conditions (i.e. temperature, pressure) differed. Figure 19 shows how the response (GAIN/HR.) varies with stean temperature and flow rate at a fixed bed depth of $5.5833 \mathrm{Ft}$.

When bed length was included as a variable (situation 2,i) with present plant constraints on steam temperature and flow rate, a gain of $\$ 124.66 / \mathrm{Hr}$. was realized at a bed depth of approximately 8.15 feet. Situation $7, i$ is analogous to the April case; only the bed length has been varied. At 8.27 feet the reactor yields $\$ 122.30 / \mathrm{Hr}$. indicating again that a longer bed improves the GAIN. A longer bed is desirable if present plant constraints cannot be removed. The only change in the cost function for cases where bed depth is also a variable was the inclusion of a penalty of approxinately $\$ .059$ per foot of extra bed per hour allowing for the cost of extra catalyst.

It seems that the cost function breaks down when all plant constraints are removed (Situation 2,ii). Depending on where the search begins, we find two optima separated by a saddle point. The optinum represented by a stean temperature of $1044.13^{\circ} \mathrm{K}$, a steam rate of $19874 \mathrm{Lb} . / \mathrm{Hr}$. , and a bed depth 
F TGURE_19

$-80-$

RESPONSE (H/HR) AS A FUECTION OF STEAM

TEMPERATURE AND FLOW RATE. (SINGLE BED)

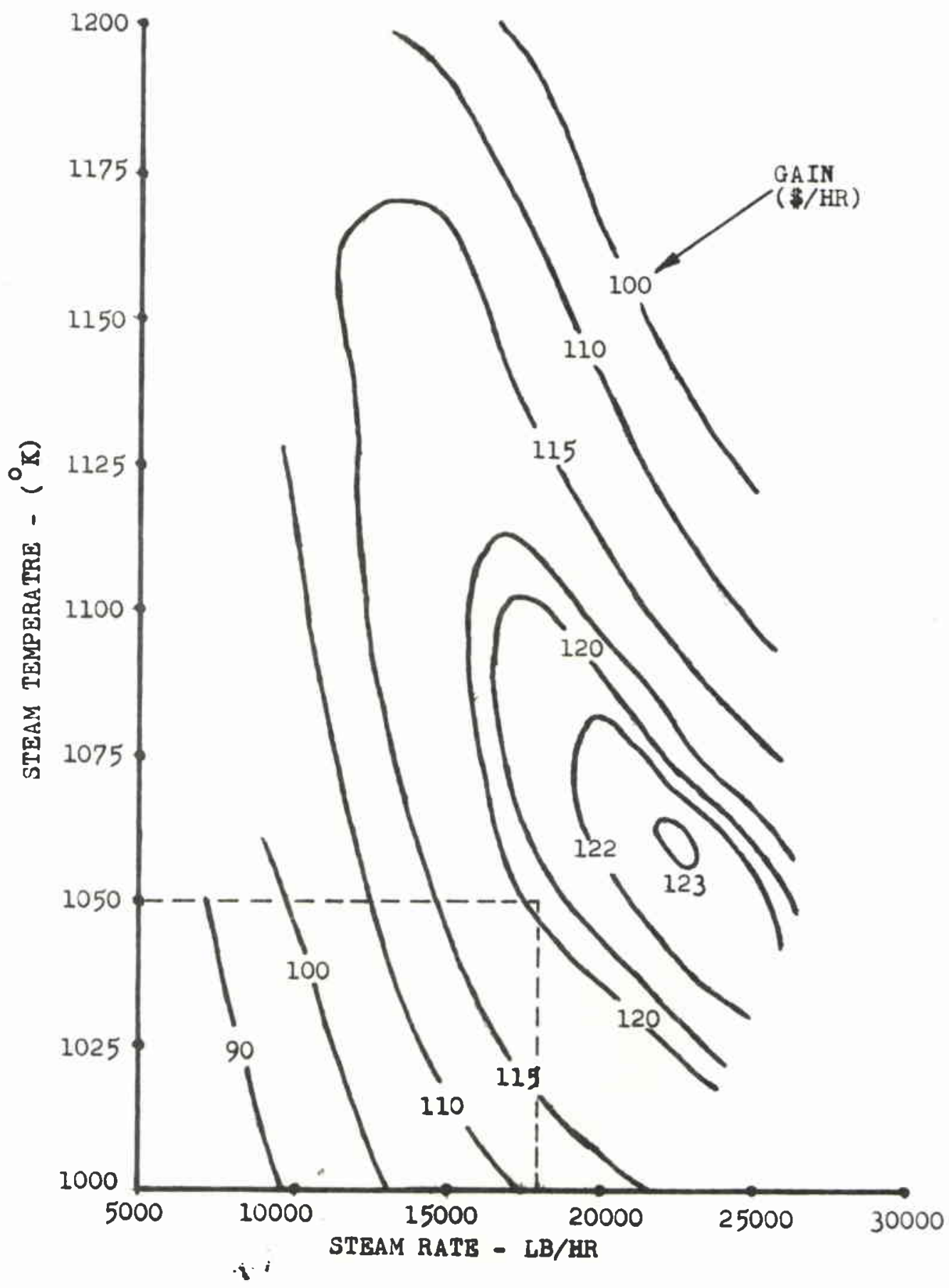


of 7.45 feet has a reasonable gain of $\$ 125.95 / \mathrm{Hr}$. The other optimuin conoition is reached at values of the variables tending towards those expected for an ideal reactor, i.e. low temperature, high steam rate and long length. This apparent failure can be explained quite simply: the cost function does not include penalties for larger furnaces, larger reactors, etc., (6.2). The Gain of $\$ 130.98 / \mathrm{Hr} .$, can be adjusted algebraically to account for such extra costs.

Figure 20 shows how the Gain behaves at various bed depths, around the local optimum of cases 1, 2, and 3 of Situation 2,ii.

\subsubsection{Conclusions}

It appears that the cost function (GAIN/HR.) is representative of the changes that occur in the reactor when the process parameters are varied over reasonable ranges around present operating conditions. Each time a constraint is removed, the GAIi increases, indicating consistency of the model.

The GAIN/HR. may be very simply improved by increasing the bed depth. The reactor has a large dead space above the bed and the addition of about one foot of catalyst should do no harm. A secondary advantage could also result. Since the catalyst is known to coke up from the reactor entrance down toward the bed interior, the reactor could be operated efficiently for a longer time due to the extra catalyst at the end of the bed. Fewer shutdowns wald be required to remove spent catalyst. 


\section{VARIABLE RESPONSE AS A FUNCTION OF STEAM}

\section{TEMPERATURE AND FLOW RATE_AT F IXED BED DEPTHS}

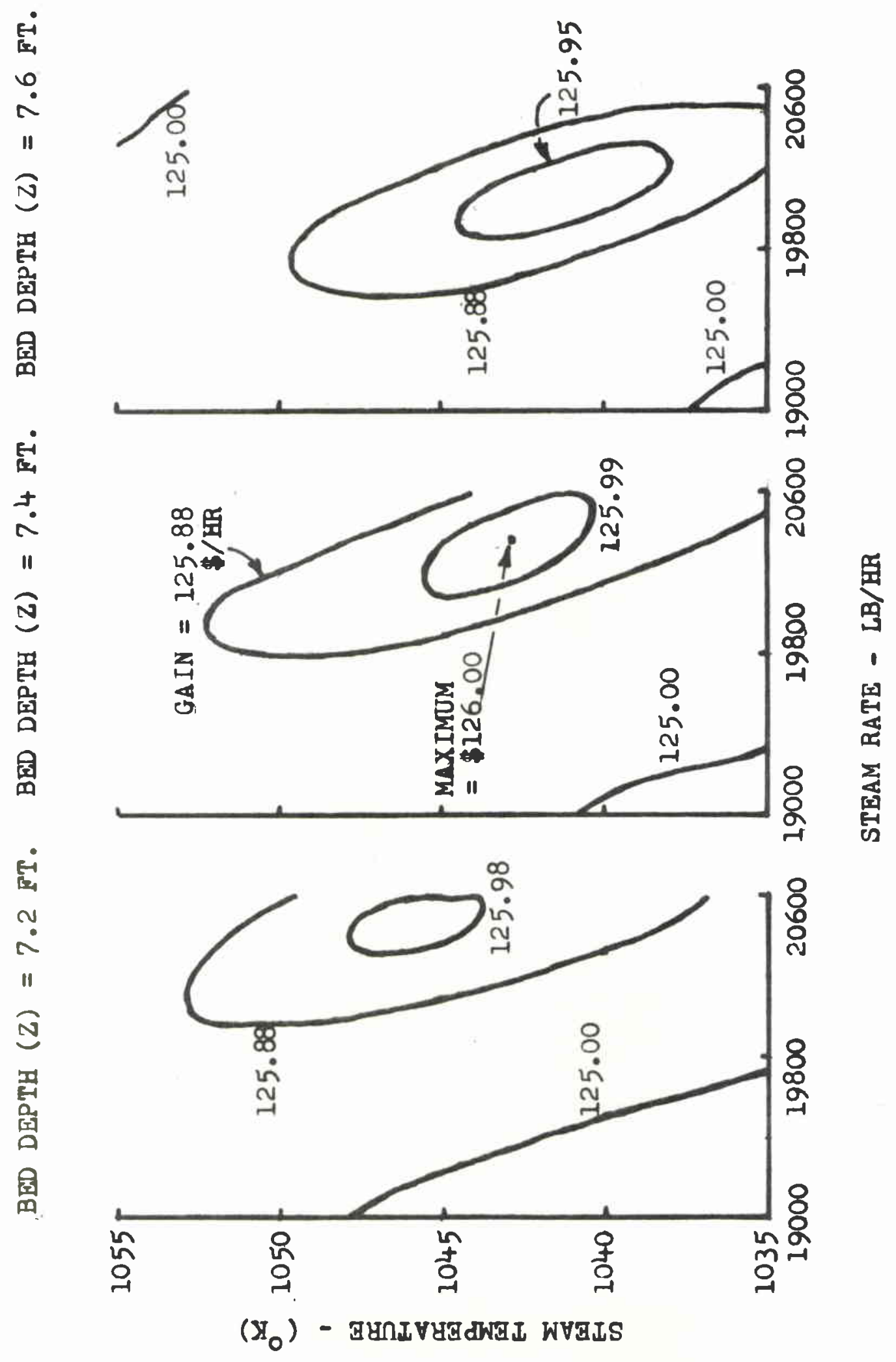


Due to the large capital cost of installing a new furnace and losses incurred during shutalown tine, it would seem that the lengthening of the bed would be econonically more feasible than increasing the steam flow rate and temperature.

\subsection{Design_and Optitimization of _a_Double Bed}

\subsubsection{Aims, variables and constraints}

Much greater improvements in GAIN are found when the jump is made fron a single to a double bed. The constraints used in this section remain similar to those used for the single bed studies (8.1). A two bed system offers certain advantages. Initially, when rates of formation of some by-products are low due to lack of reactants (i.e. $\mathrm{H}_{2}$ for reaction 3 (see 3.2 )) and the reverse rate of the main reaction is negligible, stean is mainly required for its heat. In the second bed, steam provides a means for the dilution of reactants which are vital to reactions $2,3,14,15$ and 16 . The rate of benzene formation (reaction 2) is reduced only linearly with steam added, but that of toluene is cut more drastically due to the second order nature of reaction 3. The temperature increase, of course, affects both of these reactions. The rate of reverse reaction in reaction 1 is reduced more than the forward rate. Figure 21 compares the conversion profiles of reactions 1,2 and 3 under similar constraints for a single bed (situation $1, i$ ) and a double bed (situation $6, i$ ).

The HS stream (8.1.1) was again given a temperature 
of $807^{\circ} \mathrm{K}$ for all superheated steam temperatures. The only major difference between the one and two bed models was in the treatment of inlet pressure. For single beds this had been a function of the molar flow rate $(3.6)$. In the two bed situation, this simplification was no longer valid since if most of the stean enters the second bed, the inlet pressure of the first bed would be so low that results of the 1 and 2 bed setups could not be well interpreted. It was decided to keep the inlet pressure fixed at 2.37 atmospheres for all runs where it was not a variable. This would enable relatively good comparisons with the single bed runs. The exit pressure of the first bed was considered as the inlet pressure of the second bed, no matter how the steam was introduced between beds.

The variables to be searched would consist of the:

(1) steam temperature

(2) stean flow rate to Bed 1

(3) stean flow rate to Bed 2

(4) bed length, Bed 1

(5) bed length, Bed 2

(6) inlet pressure.

Searches run with various combinations of these are illustrated in section 8.1.2 under "Reactor Situations Studies".

Complete results for each situation ( $3, i$ to $5, i i)$ are found in the Appendix sections 12 and 13. 8.2.2 Discussion of Results

In situations $3 i, 3 i i$ and $3 i i i$ the steam temperature 
and steam distribution were varied, subject to the constraints indicated with the illustrations (8.1.2). The depth of each bed was set at one half that of the existing single bed. Searches were conducted from within the permissible region ( $3 i, 1 A, 1 B$ ) or along the steam rate constraint $(3 i, 1,2,3)$ and it seems that both methods are comparable. For present plant constraints (3i, IB and $3 i, 1,2$ ) a GAIN of $\$ 123.28 / \mathrm{Hr}$. is attained. This represents quite an improvement over the $\$ 120.45$ gain of the single bed under similar constraints (1i, 1, 2). The steam stream at $1049.93^{\circ} \mathrm{K}$, must be split with $12830 \mathrm{Lb} \cdot / \mathrm{Hr}$. going to the first bed, and $5170 \mathrm{Lb} \cdot / \mathrm{Hr}$. to the second.

Situations 3 iii, 1,2 and 3 iii, $1 \mathrm{~A}$ are run with steam temperature $\leq 1200^{\circ} \mathrm{K}$ and the smaller steam rate constraint of $18000 \mathrm{Lb} \cdot / \mathrm{Hr}$. The steam distribution is now $8700 \mathrm{Lb} \cdot / \mathrm{Hr}$. to the first bed and $9300 \mathrm{Lb} . / \mathrm{Hr}$. to the second, at $1162^{\circ} \mathrm{K}$. When conpared to $3 i, 1$ the mixed feed temperature to the first bed has risen only slightly from $911.17^{\circ} \mathrm{K}$ to $921.24^{\circ} \mathrm{K}$. The gain per hour has jumped to 134.97 .

Bed lengths were varied along with steam temperature and flow rates in situations $4 i$ and $4 i i$. As the severity of the constraints imposed is reduced, the GAIN increases appropriately, again showing that the model is consistent. It would perhaps be best to consult Appendices 12 and 13 in order to compare the nunerous situations studies. When the inlet pressure $(P)$ is varied $(2.0 \leq P \leq 2.5$ atmos.), the final search value is always 2.0 atmos. Situations 
$5 i$ and $5 i i$ can be compared to $4 i$ and $4 i i$ for the effect of change of pressure but the validity of these results can be questioned owing to an apparent breakdown of the cost function. Trends, however, must be regarded as being correct, i.e. a comparison of $5 i, 1$ and $4 i, 1$ shows that a lower inlet pressure is desirable. This is confirmed by Boundy and Boyer ${ }^{5}$ who state that a typical reactor bed operates at 1.2 to 1.4 atmospheres.

\subsubsection{Conclusions}

Whenever all three basic variables, i.e. steam temperature, steam flow rates and bed lengths are varied over large ranges, the cost function seems to break down (situations 4ii, 5ii). The search halts on one or several of the constraints and algebraic adjustments allowing for costs not included (6.2) must be made if these answers are to have more meaning.

Very realistic gains are found when constraints force operations near present plant operation conditions (3i, 3ii, 3iii). In order to exploit the area close to present constraint limitations, it was decided to run a series of double bed situations ( 61 to $6 \mathrm{vi}$ ) with the constraint that the sum of the bedlengths be $\leq 5.5833$ feet (April).

When the constraints were set at $1050^{\circ} \mathrm{K}$ for steam temperature and $18000 \mathrm{Lb} / \mathrm{Hr}$. for total steam rate, it was found that most of the steam must be added to the first reactor $(3 i, 1,2)$. If stean tenperature can reach $1200^{\circ} \bar{K}(3 i i i, 1,2)$ at the sane steam rate, $8729 \mathrm{Lb} . / \mathrm{Hr}$. and $9271 \mathrm{Lb} . / \mathrm{Hr}$. steam 
at $1162^{\circ} \mathrm{K}$ are fed to beds $I$ and 2 , respectively. At lower temperatures the greater part of the steam is added to the first bed mainly for its heating ability; dilution effects are not really required until the reverse reaction rate of the main reaction and the hydrogen concentration for reaction 3 become important. At higher steam temperatures less stean is required by the first bed, i.e. approximately the same mixed feed temperature is maintained, but dilution effects are less. The steain added to the second bed is important for both its heating and dilution effects.

\subsection{Application of Two-Bed System to Present Reactor 8.3.1 Proposed changes explained}

The present single bed is about 6'2" in total length and has a surge space of about 17" between the top of the bed and the upper reactor tangent line (Figure 3). It should be possible to split the bed with a space of about $6 "$ into which steam can be added. About 4 to 5 inches, on either side of the split, must be allowed for Berl saddles, steel grating, etc. This change reduces the surge space to about 6 inches. If steam can be evenly mixed in the 6 inch split and the flow in the first bed is not disrupted, then we have a very feasible, simple change in design. Numerous situations ( $6 i$ to $6 v i$ ) have been studied to determine whether the proposed change is economically sound.

In all runs the search involves five variables; steam 
temperature, the steam rate to each bed, and the length of each bed. The sum of the bed depths was not allowed to exceed the present single bed length so thet a comparison of situations li, lii with $6 i$ to $6 \mathrm{vi}$ would be realistic. The constraints peculiar to each situation are described in section 8.1.2.

A review of the results of these searches (Appendices 12 and 13) Inaicates that it is possible to improve the present operation. For example, the comparison of $6 i$ with $1 i$, where the only difference is in the number of beds, shows that a GAIN of $\$ 120.45 / \mathrm{Hr}$. is obtained from the single bed while $\$ 124.99 / \mathrm{Hr}$. results from the two bed system. Although styrene conversion is almost exactly the same (Figure 21), the major part of the extra gain results due to much lower benzene production, caused by an overall lower operating temperature. A similar conparison exists between situation 6ii, 2 and the April case, where it is seen that there is very little to be gained if the present (tpril) operating conditions are applied to a two bed systen.

\subsubsection{Discussion of results}

The largest GAINS are to be made with a larger furnace (situations 6 iii to $6 \mathrm{vi}$ ) but it must be remembered that allowance for this is not included in the cost function so that the actual GAINS should be closer to those possible with present constraints $(6 i, 6 i i)$.

Situations $6 \mathrm{iv}, 6 \mathrm{v}$ and $6 \mathrm{vi}$ exhibit very flat response regions along the steam rate constraint. A close look at 
COMPARISON OF SINGLB AID DOUBLE BED

CONYERSION AID TBMPERATURE PROFILES
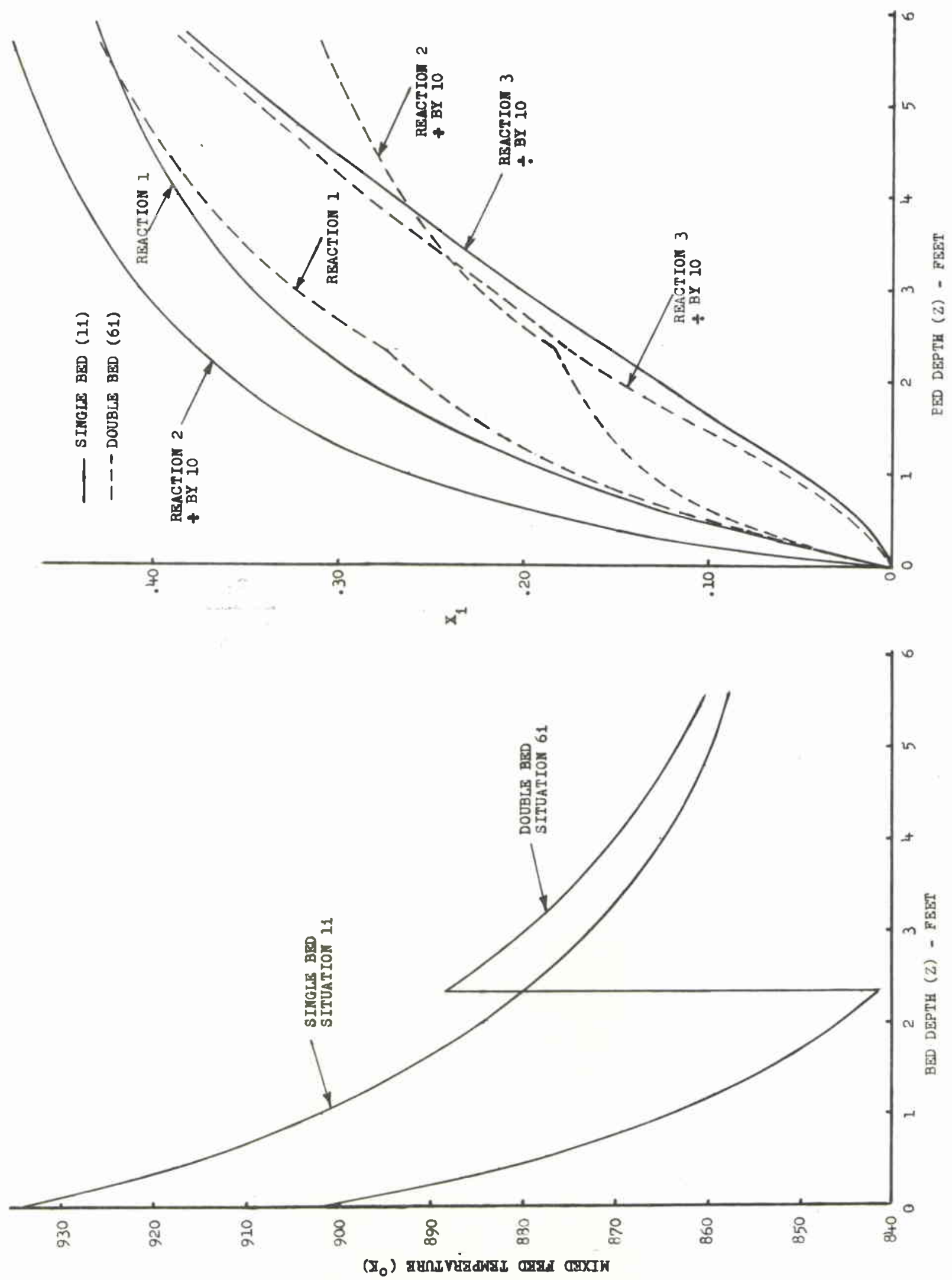
cases 1 and 2 of $6 \mathrm{iv}$ shows that when the search is started from different locations a pseudo-optimum condition is found (Case 1). The first bed is the longer of the two and also requires more steam. At the real optimum (Case 2) the first bed is the shorter of two and now requires less steam. The distributions of bed depths and steam rates have the tendency to complement one another. The permissible ranges for these varlables are large and one can operate close to the actual optimum quite easily. This pseudo-optimum where the search may terminate is explained in section 7.2. 


\section{OVRRALL CUHOLUSIONS}

(1) A suitable model of actual plant conditions for the dehydrogenation of athylbenzene has been developed. The model gives excellent results for the four najor liquid product hydrocarbons (conpare Table $1 \mathrm{C}$ with Table 3A) and a reasonably accurate gas product composition (Table ID vs. 3B). Results are well within errors that can be attributed to flowneters ( $1 \%$ is reasonable) or sanple analysis techniques. The nodel and actual plant reactor temperature profiles do not differ by more than 4 or $5^{\circ}$ at any bed depth (Figure 12).

The model allows for optinization at fixed times in the catalyst life; it can be used for the designing of new reactors; and it can give considerable insight to the relative importance of these variables.

(2) Extrapolation of the model variables in parametric and in optinization studies has show that the plant is being operated at sub-optimal conditions. This situation has resulted fron increasinos the hydrocarbon feed rate without being able to compensate by changing other process variabies, i.e. mixed feed temperature, rate of steam addition, etc. Constraints (2.3) do not permit such changes. Although an increase in styrene production has resulted due to the increased hydrocarbon throughput, the existing situation is by no means optinal with respect to the possible hourly gain at the fixed hydrocarbon rate. 
(3) Rosenbrock's multivariable search techuique has proven to be a good aethod for seeking optinum operating conditions for this reactor, system. Searches were carried out on situations having up to six variables. Computer time for each optinization was from 5 to 20 minutes (IBM 7040) with much of this being used up in the imnediate vicinity of the optimun. About 60 to 200 passes of the model were required by each run. (4) Optimization searches on the single bed (i.e. situation li) have shown that the process should be operated at a higher tenperature and a higher stean rate (Figure 19). If, however, these variables camnot be raised, the bed length should be increased (situations $2 i, 2 i i$ and $7 i$ ). It is possible to add approximately on'e foot of extra catalyst for slight inprovement (Figure 3); otherwise a furnace of greater capacity and/or a new reactor should be considered with a complete econonic survey being conducted to deternine the feasibility of such a plan. (5) If it is fearea that a higher operating tenperature will greatly reduce the useful catalyst life due to core buildup, the present April situation can be iaproved by the adoition of nore stean at the sane tenperature. By adaing 22000 1b./ar. steam at $1027.7^{\circ} \mathrm{K}$ (F'igure 18), the GEIN/Hr. would be increased from $\$ 117.31$ to approxinately $\$ 121$ (Figure 19) for the 5.5833 foot bed depth. The mixed feed temperature rises slightly from $922.59^{\circ} \mathrm{K}$ to about $935^{\circ} \mathrm{K}$. Nore steam should allow higher nixed feed tenperatures since these two variables go hand in hand in renoving and laying down carbon. 
An EVOP 7 type of search is recommended when introducing variations in process variables. Optinization runs should give the proper direction in which to head. For the present single bed the goal of such slight chenges in mixed feed temperature and stem rate should be the optimum area described by Figure 19.

(6) Sdaption of the model to the design of a two-bed reactor has shown that considerable improvement is possible (situations 6i to 6vi) over a single bed enploying an equal amount of catalyst. Unless the furnsce capacity is increased, however, the extra gains will be snall (situations 61, 6ii). The two-bed reactor allows lower operating tenperatures (compare $1 i$ and $6 i$ or the April case with $6 i i$ ) presumably resulting in less coke being deposited. Of course, there will also be less steam for coke removal in the first bed; whether the lower tenperature or lower steam rate controls coke layajown can only be estimated for the particular situation involved. Better results (6iii to $6 \mathrm{vi}$ ) seen possible with a larger furnace.

(7) If econonically feasible it is advisable that a twobed (situation 6i) reactor with steam introduction between beds be set up. Present furnace and reactor limitations need not be exceeded in order to obtain a better gain/hr. If results compare with those predicted by the nodel, serious consigeration should be given to increasing the present furnace capacity. 


\section{EUTURT WOFE}

The work of this report has been directed at predicting the inprovenent of the present plant operating situation. This has been acconplished satisfactorily with the linited data available. Tenporary optimal policies have been found for various conditions. Due to the wide scope of the work certain sections of the report were passed by rather quickly and these may demand more thorough investigation. Areas in which nore work can be done are listed for convenience: (1) At sone future date, should more data becone available, the effect of operating conditions on catelyst life could be deternined. All necessary data should be taren about once a month for the duration of the life (about 2 years) of a catalyst charge. It would then be possible to establish a crude relationship between operating temperature and stean to hyörocarbon ratio with catalyst efficiency on a time basis.

Data should be taken for new plants as soon as they go on stream. The full potential of a plant can be realized from an intensive initial study.

(2) The cost function (GLIN/HR.) could be expancied to include the items described in section 6.2 and a penalty for the effect of process variables on catalyst aging. Optimizations run on the cost function used in this report could be compared to those carried out on the nore complete cost function. A 
complete breakdown of the individual components of the total G\&IN should be given.

(3) This report has only looked at one and two reactor situations. Although it is doubtful that a three bed reactor system would offer much improvenent over the two bed situation, the three bed case should be examined.

Different means of heating the reacting mixture between beds could also be investigated.

(4) The general methods of this report can be applied to other reactor systems without requiring basic changes in the model programme structure or in the Rosenbrocks earch technique. (5) The efficiencies (accuracy and time combined) of other integration methods such as thira order Runge-Kutta or Pre-. dictor-Corrector could be compared with the fourth order FungeKutta Gill technique that was used.

(6) Other nethods of optinization should also be tried since Roseribrock's method aay not be the most suitable for this systen. Combinations of existing methods nay be desirable. For example, a steepest ascent serrch ${ }^{15}$ can be conbined with Rosenbrock's nethod; the former quickly seeks out the general location of the optimun but fails on flat response surfaces where the latter is very effective. The reaent ideas of Fletcher and Powell ${ }^{16}$ should also be considered. 


\section{RiEPERISES: (In Orger of Calling)}

I PONTRYAGIH, I. S. et al, The Mathematical Theory of Optimal Processes, Interscience, New York (1962)。

2 ARIS, Fi., Discrete Dynamic Progrening (1964).

3 RALSTOI, A., and H. S. IILF, Mathenatical lethods for Digital Conputers, wiley, (1964) pp. 110-120

4 ROSEHBROC. H. H., and C. GTOREY, Conputational Techniques for Cherical Fingineers, Permagon Press (1966), pp 64-66 Also: Rosenbrock, H. Fi., An sutomatic Ke thod for Finding the Greatest or Least Value of a Function, Computer Journal 3, (1960) pp 175-184

5 BOUNDY, R. H. and R. F. BOYAR, Styrene, Its Polymers, Copolymers anà Derivatives, Reinhold (1952)

6 (i) WENWE, $R$. R. and E. C. DYBEAL, Catalytic Dehydrogenation of Ethylbenzene. Chen. Dng. Prog. Vol. 44, No. 4 (1948).

(ii) CART S. and L. FORNI, Kinetics of Catalytic Dehydrogenation of Ethylbenzene to Styrene $I$ and $B C$ Process Design and Developnent, Vol. 4, No. 3 (1965)

(iii) Ref. 5

(iv) Assorted Polyner Corporation Internal Reports

7 BOX, G. T. P., "Evolutionery Operation: A Method for Increasing Industrial Productivity", Applied Statistics 6, 3-22 (1957).

8 MOE, J. M., Cher. Eng. Prog. 58, 11.3, 33, (1962)

9 BIRD, STEWART and LIGHTFOOT, "Transport Phenonena", iviley, p. 200, (1960)

10 JAKOTA, A. K., in a report for Polyiner Corp. in July, 1965 obtained values of $R$ arouna $1.022 \mathrm{lb}$. feed/lb. liquid hydroc aribon

11 NONDE, K. K. and A. C. DYBDAL, Catalytic Dehydrogenation of Ethylbenzene. Chen. Eng. Prog. Vol. 44, No. 4 (1943)

CARRA S. and L. FORLI, Kinetics of Catalytic Dehydrogenation of Rtrylbenzene to Styrene I and EC Process Jesign and Develognent, Vol. 4, No. 3 (1965)

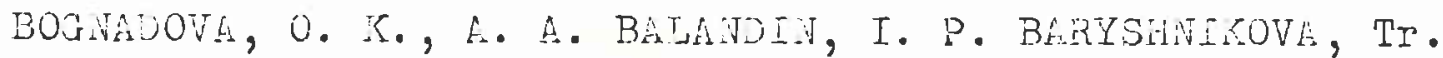
Vses. Soveschch, po. Khin. Pererabotke lleft. Uglevodorocov v Polvprod. dlya sinteza Volokoni Plast. Mass, Bâker, (1957) $2+1-7($ pub. 1960) 
BODNADOVA, O. K. A. A. BALANDIN, I. P. BELOMESTNYKHI, (Zelinskii Inst. Organ. Chem., Moscow) Izv. Akad. Nauk S.S.S.R., Otdel. Khim. Nauk 1963 (4), 611-16, cf 57, $2101 \mathrm{C}$

Girdler Catalyst Report by J. M. MOE on Ethylbenzene Dehydrogenation.

12 CAR̃RA S. And L. FORNI, Kinetics of Catalytic Dehydrogenation of Ethylbenzene to Styrene $I$ and EC Process Design and Development, Vol. 4, No. 3 (1965).

13 DAVIDSON, B. and M. J. SHAH, IBM Technical Report, Simulation of the Catalytic Cracking Process for'styrene Production, January, 1965.

14 BAASEL, W. D., Exploring Response Surfaces to Establish Optianu Conátions, Chem. Eng., Oct. 25, 1965. 147-152.

15 WILDE, J. D., Optimum Seeking Methodis, p. 107 (1964).

16 FIETCHER, R. and M. J. D. PONELI, A Rapidly Convergent Descent Method for Minimization, Computer Journal, Vol. $6(1963-64)$, p. 163 
APPENDIX 1

CHOICE OF EOUILIBRIUM CONSTANT

$\left(K_{p}\right)$ EXPRESSION FOR MÁ IN REACTION

Two expressions for $K_{p}$ as a function of temperature were found. Another, derived from first principles, was compared with these and since it gave $K_{p}$ values intermediate between the two it was used in the rate expression (3.3).

An exposé of the expressions is given below.

(i) THE $K_{p}$ EXPLESSIONS

EQUATION

NUMBIR

1

2

3
EQUATION FOR $\mathrm{K}_{\mathrm{D}}$

$K_{p}=\operatorname{EXP}(-15350 / T+16.12)$

$K_{p}=T \cdot 549 \operatorname{EXP}(-14516 / T+11.41)$

$$
K_{p}=\operatorname{EXP}\left(-\Delta F^{\circ} / R T\right)
$$

REFERENCE

G

$\mathrm{H}$

Note: (1) Equation 3 was used in the final model.

(2) References follow Appendix 3.

ABOVE NOMEINCLATURE

$$
\begin{aligned}
\mathrm{T} & =\mathrm{O}_{\mathrm{K}} \\
\mathrm{R} & =1.987 \mathrm{CAI} /\left(\mathrm{G}, 1 . \mathrm{MOL} . \mathrm{O}_{\mathrm{K}}\right) \\
\Delta \mathrm{F}^{\mathrm{O}} & =\left(\mathrm{a}+\mathrm{bT}+\mathrm{cT}^{2}\right) \mathrm{CAL} / \mathrm{GM} . \mathrm{MOL} \text {. (See Ref. I) } \\
\mathrm{a} & =29311 \\
\mathrm{~b} & =-30.157 \\
\mathrm{c} & =-.000524
\end{aligned}
$$




\section{(ii) EQUATION_2 DERIVATION}

$$
\frac{d\left(\ln K_{p}\right)}{d T}=\frac{\Delta H^{\circ}}{R T^{2}}=\frac{28843+1.09 T}{R T^{2}}
$$

(See 3.8 or main body for $\Delta \mathrm{H}^{\circ}$ )

$$
\text { but at } 956^{\circ} \mathrm{K}, \mathrm{K}_{\mathrm{p}}=1 \quad \text { (Ref. } \mathrm{H} \text { ) }
$$$$
\text { In } K_{p}=-\frac{14516}{T}+.549 \ln T+g
$$

$$
\begin{aligned}
& 0=-\frac{14516}{956}+.549 \ln 956+g \\
& g=11.41
\end{aligned}
$$

\begin{tabular}{|c|c|c|c|}
\hline $\begin{array}{l}\text { TEMP ERATURE } \\
\mathrm{O}_{\mathrm{K}} \\
\end{array}$ & EQUATION 1 & EQUATION 2 & EQUATIOH 3 \\
\hline 750 & $.125499 \mathrm{E}-01$ & $.134302 \mathrm{E}-01$ & .136564 E-01 \\
\hline 770 & $.220363 \mathrm{E}-01$ & $.225261 \mathrm{E}-01$ & .228820 E-O1 \\
\hline 790 & .365023 E-OI & . 368191 E-O1 & . 373610 E-01 \\
\hline 810 & .589764 E-O1 & .587587 E-O1 & $.595581 \mathrm{E}-\mathrm{O}$ \\
\hline 830 & $.931098 \mathrm{E}-01$ & .917128 E-OI & $.928566 \mathrm{E}-\mathrm{O} 1$ \\
\hline 850 & .143873 E 00 & .140224 E 00 & $.141813 \mathrm{E} 00$ \\
\hline 870 & .217909 E 00 & .210314 E00 & .212457 E 00 \\
\hline 890 & .323942 E 00 & .309830 E 00 & $.312635 \mathrm{E} 00$ \\
\hline 910 & $.473250 \equiv 00$ & $.448850 \geq 00$ & .452408 E 00 \\
\hline 930 & $.680195 \mathrm{E} 00$ & $.640129 \mathrm{E} 00$ & $.644^{\prime}+94$ E 00 \\
\hline 950 & .962314 E 00 & .899602 E 00 & .904759 E 00 \\
\hline
\end{tabular}

Therefore

$$
\begin{aligned}
\ln K_{p} & =-\frac{14516}{T}+.549 \ln T+11.41 \\
K_{p} & =T .549 \operatorname{IXP}(-14516 / T+11.41)
\end{aligned}
$$

(iii) A COMPARISON OF VALUES OF $\mathrm{K}_{\mathrm{p}}$ OF EQUATIONS $1,2,3$ 
APPENDIX 2

ACTIVATION ENEERGIES

\begin{tabular}{c|c|c}
\begin{tabular}{l|l} 
REACTION \\
NUIBER
\end{tabular} & $\begin{array}{c}\Delta \text { T } \\
\text { CAI/GM.MOL. }\end{array}$ & $\begin{array}{c}\text { REFERENCE } \\
\text { NUMBER }\end{array}$ \\
\hline 1 & 21708 & A \\
2 & 49675 & B \\
3 & 21857 & C \\
14 & 24838 & D \\
15 & 15697 & E \\
16 & 17585 & F
\end{tabular}

Note: References follow Appendix 3

\section{APPEIDIX_3}

FREQUTHCY FHCTORS I.E. $\left(A_{i}\right.$ OF EXP $\left.\left(-\Delta E_{i} / R T+A_{i}\right)\right)$

These frequency factor exponents $\left(A_{i}\right)$ were found by the

Rosenbrock search technique described in (7.1). Section (5.1) of the main body discusses frequency factors.

FREOUERTY FACTORS FOR VARIOUS CASES

\begin{tabular}{|c|c|c|c|c|}
\hline $\begin{array}{l}\text { REACTIONN } \\
\text { NUABER }\end{array}$ & FUR ${ }^{A} A_{R I L}$ & FOR $\stackrel{A_{i}}{\text { MA }}$ & 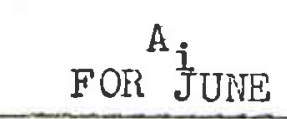 & FOR ${ }^{A_{1}}$ POLY-29 \\
\hline 1 & 8.1033 & 8.1614 & 8.0272 & 8.2907 \\
\hline 2 & 13.2392 & 13.2654 & 13.0719 & 13.2294 \\
\hline 3 & 0.2961 & 0.4075 & 0.1219 & 0.2741 \\
\hline 14 & -0.0724 & -.1882 & 0.1129 & -.1137 \\
\hline 15 & -2.9344 & -2.9408 & -2.2596 & -3.0570 \\
\hline 16 & 21.2402 & $21: 1607$ & 21.1493 & 21.3021 \\
\hline $\begin{array}{l}\text { CATALYST } \\
\text { AGE (HRS.) }\end{array}$ & 8850 & 9700 & 10350 & $\begin{array}{l}\text { ABOUT } \\
20000\end{array}$ \\
\hline
\end{tabular}




\section{REEERFNCES TO APPEND ICES 1, 2 AND 3.}

REFERTNCE

NUI:IBER

A

B

C

D

E

$\bar{F}$

G

$\mathrm{H}$

I

\section{REFERENCE}

See Ref. H.

See Ref. H.

See Ref. H.

This value was estimated

AKERS, N. N. and CAMP, O.P., ACCHE, NO. 4, 471

(Dec. 1955). We assume the nature of the catalytic reaction to be the same, although the catalysts differ.

MOE, J. M. CHEY. ENG. PROG. 58 N.3 33, (1962). Again although the catalysts difer, the $\Delta \mathrm{F}$ of this paper was used.

BOGDANOVA, O. K., A. P. SCHEGLOVA, A. A. BALANDIN, I. P. BLiO.ESTYYH, Petroleum Chen. U.S.S.R. I, I, 120 (1962)

WENNTR, R. R., and DYBDAL, E. C., CHEM. ENG. PROG. $44, N .4,275,(1948)$

$\mathrm{F}^{\circ}$ vs. T data was obtained from: BOUNDY AND BOYER, "STYRENE, Its polymers, Copolymers, and Derivatives", Reinhold ( 1952 )

A second order polynomial was fitted to the $F^{0}$ vs $T$ values (I.E. $\Delta \mathrm{F}^{\mathrm{O}}=\mathrm{a}+\mathrm{bT}+\mathrm{cT}^{2}$ ) 


\section{APPENDIX 4}

$\triangle H$, LINEAR VS. CUBIC FUIJCTIUN OF TEIPERATURE

A comparison between linear anà cubic expressions of the heat of reaction $(\Delta H)$ as a function of temperature is offered for the main reaction. Similar results are obtained for the other five reactions. The cubic $\Delta H_{1}$ equation was derived from

$$
\Delta H_{T}=\Delta H_{298}+\int_{298}^{T} \Delta\left(n C_{p}\right) d T
$$

where $\Delta\left(n c_{p}\right)$ is of the form $a+b T+c T^{2}$

All $C_{p}$ data is as in the Table $e_{\wedge} 3.8$ while $\Delta \mathrm{H}_{298}$ for reaction 1 is 28,100 cal./gm.mole (Ref. 3, Sect. 3.8). At worst, as shown in the table below, an error of approxinately $30 \mathrm{cal} . / \mathrm{gn} . \mathrm{mol}$. on 30000 results.

$\triangle H_{I}$ FROM LINEAR AND CUBIC EXPRESSIONS

\begin{tabular}{c|c|c}
${ }_{\mathrm{K}}^{\mathrm{T}}$ & $\begin{array}{c}\Delta \mathrm{H}_{\mathrm{T}}=\mathrm{a}+\mathrm{bT} \\
\mathrm{CAL} \cdot / \mathrm{GH} . \mathrm{MOL} .\end{array}$ & $\Delta \mathrm{H}_{\mathrm{T}}=\Delta \mathrm{H}_{2980}+\int_{298}^{\mathrm{T}} \Delta\left(\mathrm{NC}_{\mathrm{p}}\right) \mathrm{dT}$ \\
\hline 750 & 29660.50 & 29649.01 \\
800 & 29715.00 & 29726.59 \\
850 & 29769.50 & 29739.24 \\
900 & 29824.00 & 29837.98 \\
950 & 29878.50 & 29873.84 \\
1000 & 29933.00 & 29897.83
\end{tabular}


We can conclude that although a linear expression for $\Delta H$ aoes not warrant quadratic $C_{p}$ 's, this simplification has done little harm. Much computation tine has been saved. 


\section{APPEUDIX 5}

\section{SINGIS BED ETHYISENZEIE DEHYDROGENATIOR MODEL}

(1) Explaination of Major Terms

$A(5), B(5), C(5) \ldots$ Runge-Kutta constants. See Major Reference 3 $\mathrm{Hl}, \mathrm{H} 2 \ldots . . . \ldots$........

$$
\Delta \mathrm{H}_{i}=\mathrm{HL}(\mathrm{i})+\mathrm{H} 2(\mathrm{i}) \times \mathrm{T} \ldots . .\left(\mathrm{T}=\mathrm{O}_{\mathrm{K}}\right)
$$

$A A A, B B B, C C C \ldots \ldots \Delta F^{O}=10 J 0 x\left(A A A+B B B X T+\operatorname{CCCXT}^{2}\right)$

$$
=\mathrm{cal} \cdot / \mathrm{gm} \cdot \mathrm{mol} \text {. }
$$

$\mathrm{Cl}_{1}, \mathrm{C}_{2}, \mathrm{C} 3 \ldots \ldots \ldots \mathrm{C}_{\mathrm{p}}$ coefficients, $\mathrm{i} \cdot \mathrm{e} \cdot \mathrm{C}_{\mathrm{p}}=\left(\mathrm{Cl}+\mathrm{C} 2 \mathrm{xT}+\mathrm{C} 3 \mathrm{x \textrm {T } ^ { 2 }}\right)$

$$
\mathrm{C}_{\mathrm{P}} \text { in cal./Em.nol } \mathrm{O}_{\mathrm{K}}
$$

WTMOL............ Compound molecular weights

AMTCMD.............. Compound flow rates - Lb./Hr.

AMTSEC............. Conpound flow rates - Lb.Mol./Sec.

RKK............. $\Delta \mathrm{N} / \Delta \mathrm{Z}$, rate of change of conversion

(mole fraction) with bed depth (Feet)

X...............Mle fraction conversion

R.............. of $\operatorname{ExP}(-\Delta \mathrm{E} / \mathrm{RT}+\mathrm{A})$

Q........................ Major Reference 3

DIAY............... dianeter (feet)

ZLAST.............. leng th (feet)

CATwT............Bulk density of catalyst (Lb./Ft. ${ }^{3}$ )

E................... voidage

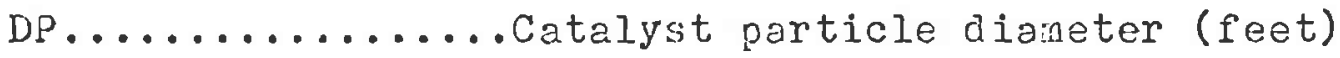

iNSTEP...............numer of integration steps

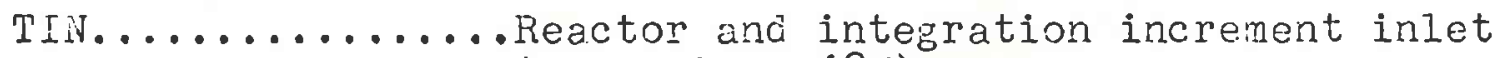
temperáture $\left({ }^{\circ} \mathrm{K}\right)$ 
PIN.............Reactor and integration increnent inlet pressure (atnos.)

NRCT.............. Number of reactions

N............... Number of compounds

AVMLIT............Mixed feed mean molecular weight

DINGAS.............Gaseous feed density Ib./Ft. 3

vo.................eed superficial velocity (Ft./Sec.)

HEGTIN..............Stream heat content (B.T.U./Lb.MOl. ${ }_{\mathrm{K}}$ )

HEATRX................eat of reaction (B.T.U./Lb.Mol.)*

* Note: essentially we have these units. Unit conversion

factors, $i$. e. $1.8 \mathrm{~F}^{\circ} /{ }^{\circ} \mathrm{C}$. have been internally cancelled

(2) Model

A complete FoRTRls IV listing of the single bed model now follows. Terms that have not been defined above, are defined internally within the progranme, which is set up in such a way that formulae verification should be a simple exercise. 
SIMULATION OF ETHYLBENZENE DEHYDROGENATION

RUNGE-KUTTA-GILL (4TH ORDER) PERFORMED ON REACTIONS

TEMP AND PRES ARE CHANGED ONCE FOR EVERY COMPLETE R-K-G INCREMENT

FOLLOWING BASIC REACTIONS ONLY USED

$\mathrm{C} 6 \mathrm{H} 5 \mathrm{C} 2 \mathrm{H} 5=\mathrm{C} 6 \mathrm{H} 5 \mathrm{C} 2 \mathrm{H} 3+\mathrm{H} 2$

$\mathrm{C} 6 \mathrm{H} 5 \mathrm{C}_{2} \mathrm{H} 5=\mathrm{C} 6 \mathrm{H} 6+\mathrm{C}_{2} \mathrm{H}_{4}$

$\mathrm{H} 2+\mathrm{C}_{2} \mathrm{H} 5 \mathrm{C} 2 \mathrm{H} 5=\mathrm{C} 6 \mathrm{H} 5 \mathrm{CH} 3$
$\mathrm{H} 2 \mathrm{O}+1 / 2 \mathrm{C}_{2} \mathrm{H}_{4}=\mathrm{CO}+2 \mathrm{H} 2$

$\mathrm{CH}_{4}+\mathrm{H}_{2} \mathrm{O}=\mathrm{CO}+3 \mathrm{H} 2$

$\mathrm{CO}+\mathrm{H} 2 \mathrm{O}=\mathrm{CO} 2+\mathrm{H} 2$

COMPOUNDS AND CORRES NUMBERS ARE

$1=\mathrm{EB} \quad 2=\mathrm{STY} \quad 3=\mathrm{H} 2 \quad 4=\mathrm{C}_{2} \mathrm{H}_{4} \quad 5=\mathrm{C} 6 \mathrm{H} 6 \quad 6=\mathrm{C}_{6} \mathrm{H}_{5} \mathrm{CH}_{3}$ $\begin{array}{lllll}7=\mathrm{CH} 4 & 8=\mathrm{C} 2 \mathrm{H} 6 & 9=\mathrm{C} 2 \mathrm{H} 2 & 10=\mathrm{C} 6 \mathrm{H} 5 \mathrm{C} 2 \mathrm{H} & 11=\mathrm{H} 2 \mathrm{O}\end{array}$

DIMENSION $A(5), B(5), C(5), H 1(16), H 2(16), A A A(16), B B B(16), C C C(16)$, $1 C 1(16), C 2(16), C 3(16)$, WTMOL (16), AMTCMD (16), AMTSEC (16), RKK (6, 5), $2 Q(6,5), X(6,5)$, AMTLBM(16), R(6), ALL $(14)$

READ $(5,405)(R(I), I=1,6$

READ $(5,406)$ NSTEP, TIN

$\operatorname{READ}(5,6)$ ( AMTCMD (I), I $=1,14$

READ $(5,11)$ DIAM, ZLAST, CATWT, Z,E,DP

$\operatorname{READ}(5,10)(A(J), B(J), C(J), J=1,5)$

$\operatorname{READ}(5,2)(H 1(1), H 2(1), I=1,10)$

$\operatorname{READ}(5,3)$ AAA $(1), B B B(1), C C C(1)$
$\operatorname{READ}(5,1)(C 1(1), C 2(1), C 3(1), I=1,14)$

READ $(5,1)(C 1(I), C 2(I), C 3(1)$
$\operatorname{READ}(5,4)(W T M O L(I), I=1,14)$

405 FORMAT (6F10.4)

406 FORMAT (I $4, F 10.2$

6 FORMAT $(7 F 10.2)$

11 FORMAT (6F10.4)

10 FORMAT (3F20.5)

2 FORMAT (2E12.6)

3 FORMAT (3E15,8)

FORMAT (3E12.6)

4 FORMAT $(7 F 10.2)$

C INITIALIZATION FOLLOW

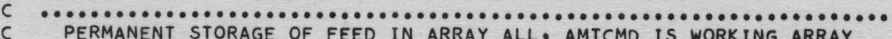
DO $112 \quad \mathrm{I}=1,14$

$112 \mathrm{ALL}(\mathrm{I})=\operatorname{AMTCMD}(\mathrm{I})$

NRCT $=6$

$N=14$

OFE $=144 \cdot * 14 \cdot 7 * 32.2$

$E E L=E * E * E$

AREA $=3.1416 *(D 1 A M / 2 \cdot) * * 2$

EFF $=A R E A * C A T W T$

U.

DO $33 \quad \mathrm{I}=1$, NRCT

$X(1,1)=0.0$

$Q(I, 1)=0.0$

$33 \operatorname{RKK}(1,1)=0.0$

C INITIAL FLOWS OF COMPONENTS IN FEED AND PARTIAL PRESSURES

DO $21 \quad I=1, N$

AMTLBM (I) $=A M T C M D(I) / W T M O L$ (I)

21 AMTSEC $(1)=A M T L B M(1) / 3600$

FEBO =AMTSEC(1)

FSTYO $=A M T S E C(2)$

FH2O $=A M T S E C(3)$

$F C 2 H 4 O=A M T S E C(4)$

$F B Z O=A M T S E C(5)$

FTOLO $=A M T S E C(6)$

FCH4O=AMTSEC (7)

$F C 2 \mathrm{H} 60=A M T S E C(8)$

$F C 2 H 2 O=A M T S E C(9)$
$F R C 2 H O=A M T S E C(10)$

$F R C 2 H O=A M T S E C$
$F H 2 O O=A M T S E C(11)$

$F H 200=A M T S E C(11)$
$F C O O=A M T S E C(12)$

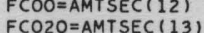

FCO2O=AMT SEC $C(13)$

$F C O=A M T S E C$
SUMML $S=0.0$

DO $22 \quad \mathrm{I}=1, \mathrm{~N}$

22 SUMMLS $=$ SUMML S+AMTSECIII)

PIN $=1.046+.00122 *($ SUMMLS*3600.)
SUMIN $=$ SUMML S-FEBO

C FEED DENSITY, VELOCITY, AND AVE MOLECULAR WEIGHT

AVMLWT $=0.0$

DO $24 \quad 1=1, N$

24 AVMLWT $=$ AVMLWT+WTMOL ( I) *AMTSEC $(1) /$ SUMMLS

DENGAS =PIN*AVMLWT $(1,314 *$ TIN I

VO $=S U M M L S *(T I N * 359 . /(273 . * P I N)) / A R E A$

C PRINT OUT CARDS FOLLOW BELOW WRITE $(6,53)$

53 FORMATI 1 H1, $10 X, 76 H$ SIMULATION OF ETHYLBENZENE CONVERSION TO STYREN $1 E$ ASSUMING ADIABATIC REACTOR / $11 X, 25 \mathrm{H}$ PROGRAMMED BY JOHN SHEEL)

WRITE $(6,52)$ TIN, PIN, ZLAST, H, AVMLWT, DENGAS, VO

2 FORMAT 1LET PRESSURE $=, F 13.3,4 \mathrm{H}$ ATM/20X,13H BED LENGTH $=, F 17.5,5 \mathrm{H}$ FEET/20X $2,19 \mathrm{H}$ LENGTH INCREMENT $=, F 11.6,5 \mathrm{H}$ FEET/20X,23H AVERAGE MOLECULAR W $3=, F 7.3 / 20 X, 15 \mathrm{H}$ FEED DENSITY $=, F 15.6,7 \mathrm{H}$ LB/FT3/20X,23H SUPERFICIAL WRITE $(6,408)$ I NSTEP

408 FORMAT $(1 \mathrm{H}, 7 \mathrm{H}$ NSTEP $=, 14$

WRITE $(6,407)(R(I), I=1,6)$

407 FORMAT ( $1 \mathrm{H} / 22 \mathrm{H}$ FREQUENCY FACTORS ARE/6F15.4) WRITE $(6,61)$

61 FORMAT I//////20X,16H COMPOUND NUMBER, $5 \mathrm{X}, 16 \mathrm{H}$ POUNDS PER HOUR, $5 \mathrm{X}$,

WRITE $(6,62)(N N, A M T C M D(N N), A M T S E C(N N), N N=1, N)$

62 FORMAT $(1 \mathrm{H}, 20 \mathrm{X}, 110,14 \mathrm{X}, \mathrm{F} 10,3,11 \mathrm{X}, \mathrm{F} 11,7)$

WRITE $(6,44)$

44 FORMAT $(1 H 1,3 X, 7 H$ LENGTH, $8 X, 6 H$ TEMP, $8 X, 6 H$ PRES, $8 X, 6 H$ X1, $8 X$, $16 \mathrm{H} \times 2,8 \mathrm{X}, 6 \mathrm{H} \times 3,8 \times, 6 \mathrm{H} \times 4,8 \times, 6 \mathrm{H} \times 5,8 \times, 6 \mathrm{H} \times 6$

45 FORMAT $(1 \mathrm{H}, 9 \mathrm{E} 14.5)$ c END OF INITIAL PRINTOUT

C END OF INITIAL PRINTOUT
C END OF INITIALIZATION

c

C RUNGE-KUTTA INTEGRATION BEGINS

DO 7 NSEC $=1$, NSTEP

$R S T=(A A A(1) / T I N+B B B(1)+C C C(1) * T I N) * 1000.11 .987$

FACEB $=E F F / F E B O$

$\mathrm{FACST}=\mathrm{EFF} / \mathrm{FH} 200$

$E X I=E X P(-10925 . / T I N+R(1))$

$E \times 2=E X P(-25000 . / T I N+R(2))$

$\operatorname{EX3}=\operatorname{EXP}(-11000 . / T I N+R(3))$

EX4 =EXP $\left(-12500_{0} / T I N+R(4)\right)$

EXS $=$ EXP $(-7900.0 / T I N+R(5))$

EX6 $=E X P(-8850.0 / T I N+R(6)$

C BASIC RUNGE-KUTTA INTEGRATION

DO $100 \mathrm{~J}=2,5$

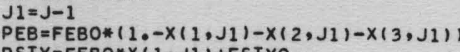

PST $Y=F E B O * X(1, J 1)+F S T Y O$

$P C O=F H 2 O O *(X(4, J 1)+X(5, J 1)-X(6, J 1))+F C O O$

$P H 2 O=F H 200 *(1,-x(5, J 1)-x(6, J 1)-x(4, J 1))$

$P C H 4=F E B O * X(3, J 1)+F C H 4 O-F H 2 O O * X 15, J 1$

PH2=FEB

PTOTAL

(,JI)

POST $=$ PIN $/$ PTOTAL

RKK $1, J)=F A C E B * E X 1 * P O S T *(P E B-P S T Y * P H 2 * P O S T / S S T) / 3600$.

$R K K(2, J)=F A C E B * E X 2 * P E B * P O S T$

RKK $(3, J)=F A C E B * E X 3 * P E B * P H 2 * P O S T * P O S T$

$R K K(4, J)=F A C S T * E X 4 * P H 2 O * S Q R T(P C 2 H 4 * P O S T) * P O S T$

RKK $15, J)=F A C S T * E X 5 * P C H 4 * P O S T$

RKK $(6, J)=$ EX66*FACST *EX6*PH2O*PCO*POST*POST
DO $92 \mathrm{I}=1$, NRCT

$x(1, J)=X(1, J)+H *(A(J) *(\operatorname{RKK}(1, J)-B(J) * Q(1, J]))$

$92 Q(I, J)=Q(I, J 1)+30 *(A(J) *(R K K(I, J)-B(J) * Q(I, J 1)))-C(J) * R K K(I, J)$

c BASIC RUNGE-KUTTA INTEGRATION ENDS FOR MATERIAL BALANCES

c

CALCULATIONS TO UPDATE TEMPERATURE, PRESSURE, AND COMPOUND FLOWS

-...............

DO $56 \quad I=1, N$

56 HEATIN=HEATIN+AMTSEC(I)*(C1 $\left.(I)+C_{2}(I) * T I N+C_{3}(I) * T I N * T I N\right)$

$J=5$

AMTSEC $(1)=F E B O *(1,0-X(1, J)-X(2, J)-X(3, J))$

AMTSEC $(3)=F E B O *(X(1, J)-X(3, J))+F H 2 O+F H 2 O O *(3, * x(5, J)+X(6, J)+$

$12.0 * \times(4, J))$

AMTSEC ( 4$)=F E B O * X(2, J)+F\left(2 \mathrm{H}_{40}-\mathrm{FH} 2 \mathrm{OO} * 0.5 * \times(4, J)\right.$

AMTSEC (5) $=F E B O * X(2, J)+F B 20$

AMTSEC $(7)=F E B O * X(3, J)+F C H 40-F H 200 * X(5, J)$

AMTSEC $(11)=F H 2 O O *(1,0-x(5, J)-x(6, J)-x(4, J)$

AMTSEC $(12)=F H 2 O 0 *(X(5, J)-X(6, J)+X(4, J))+F C O O$

AMTSEC (13) $=F H 200 * x(6, J)+F C O 20$

SUMML $S=0.0$

DO $50 \quad I=1, N$

SUMMLS $=S U M M L S+A M T S E C$ (I)

HEATR $X=0.0$
DO $57 \quad M=1,3$

57 HEATRX $=H E A T R X+(X(M, 5)-X(M, 1))$ \#FEBO* $(H 1(M)+H 2(M) * T I N)$

DO $691 \mathrm{M}=1,3$

691 HEATRX $=$ HEATRX $+(X(M+3,5)-X(M+3,1)) * F H 2 O O *(H 1(M+3)+H 2(M+3) * T I N)$

TI $N=T$ I $N-H E A T R X / H E A T I N$
DPT $=V O *(1 .-E) /(E E L * D P) *(150 * U *(1,-E) / D P+1.75 * D E N G A S * V O) / O F E * H$ $P I N=P I N-D P T$

AVML $W T=0.0$

DO $34 \quad \mathrm{I}=1$,

34 AVMLWT =AVMLWT+WTMOL ( 1 ) *AMTSEC( 1 ) / SUMMLS

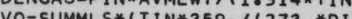

(N) I/AREA

DO $97 \quad I=1$, NRC

$x(1,1)=x(1,5$
$0(1,1)=0(1,5)$

$Q(1,1)=Q(1,5)$

WRITE $(6,45) Z$, TIN,PIN, $(X(I, 1), I=1$, NRCT

7 CONTINUE

RUNGE-KUTTA INTEGRATION ENDS

C

FINAL PRINTOUT

DO $66 \mathrm{I}=1, \mathrm{~N}$

AMTLBM $(I)=A M T S E C(I) * 3600$

66 AMTCMD (1) =AMTLBM(I)*WTMOL (I)

WRITE $(6,63)$

63 FORMAT $(1 \mathrm{H})$, 2 OX

WRITE $(6,61)$ (22H AT EXIT CONDITIONS...

WRI TE $(6,62)$ (NN, AMTCMD (NN), AMTSEC (NN), NN $=1$, N) STOP

SENTRY

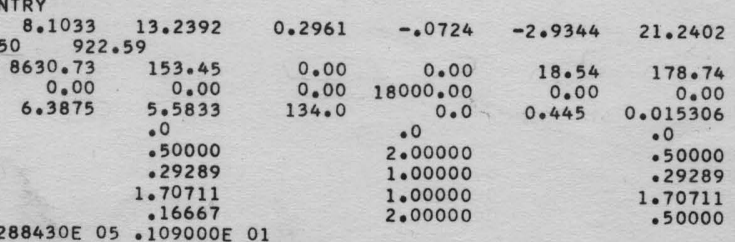

0.00 
.259920E 05-.190000E 01

-.127020 E $05-.315000$ E 01

$.196020 E$ O5 .211000E 01

.500460 E $05 \cdot 396000 E$

108020E 05 .25000e 01

DOD

DODOD 00 .000000E 00

. DONODE 00 .00000

$0.29310942 E \quad 02-0.30157089 E-01-0.52385439 E-06$

.223000 E 01.110000 E O0-.367000E-0

.407000 E $01.097700 E$ O0-.331000E-04

$.694700 E$ 01-.200000E-03 $.481000 E-06$

$.283000 E$ O1 .286010E-01-.872600E-05

$.409000 \mathrm{E}$ O1 . $776210 \mathrm{E}-01-.264260 \mathrm{E}-04$

.576000 E $00.934930 \mathrm{E}-01-.312270 \mathrm{E}-04$

$.338100 \mathrm{E} 01.180440 \mathrm{E}-01-.430000 \mathrm{E}-05$

$.224700 E$ O1 $0382010 \mathrm{E}-01-.110490 \mathrm{E}-04$

$.733100 E$ O $01.126220 E-01-.388900 E-05$

$.347000 \mathrm{E}$ O1 $.919000 \mathrm{E}-01-.314000 \mathrm{E}-04$

.725600 E O1 $.229800 E-02.283000 E-06$

.642000 E O1 $166500 \mathrm{E}-02.196000 \mathrm{E}$

(400E O1 .103960E-01-.354500E

$\begin{array}{lllllll}106.16 & 104.14 & 2.02 & 28.05 & 78.11 & 92.13 & 16.04 \\ 30.07 & 26.00 & 102.00 & 18.00 & 28.01 & 44.01 & 12.00\end{array}$

SIBSYS

CD TOT 0260 


\section{APPENDIX 6}

\section{POLY-29 CASES FUN WITH VEA:D POLY-29}

CASE FREQUEIOUY FACTOSS

Hotes: (1) Each case was run with inlet pressure varying linearly with total nolar flow rate $(3.6)$

(2) Inlet conaitions for each case vary in the ranges (3) Only the product flows of the main conponents are
followed below.

\begin{tabular}{|c|c|c|c|c|}
\hline $\begin{array}{l}\text { ChSis } \\
\text { INUMBDR }\end{array}$ & $\begin{array}{c}\text { ETHYLBENZEINE } \\
\text { LB./Fin. }\end{array}$ & $\begin{array}{l}\text { STYRLEUT } \\
\text { LB./HTR. }\end{array}$ & $\begin{array}{l}\text { TOLUEITE } \\
\mathrm{LB} . / \mathrm{FR} \text {. }\end{array}$ & $\begin{array}{l}\text { BENZNES } \\
\text { LB./HR. }\end{array}$ \\
\hline$\left\{\begin{array}{c}\text { PULY-29 MEAN } \\
\text { CHSE } \\
(\text { See. } 4.1 \& \\
5.3)\end{array}\right.$ & & - & & \\
\hline $\begin{array}{l}\text { Plant Results } \\
\text { Model Results } \\
\text { Deviation }\end{array}$ & $\begin{array}{r}3971.67 \\
3975.12 \\
3.45\end{array}$ & $\begin{array}{l}3520.38 \\
3517.13 \\
(3.25)\end{array}$ & $\begin{array}{c}531.43 \\
526.13 \\
(5.30)\end{array}$ & $\begin{array}{r}213.07 \\
209.51 \\
(3.66)\end{array}$ \\
\hline 1 & $\begin{array}{r}3836 \cdot 36 \\
3881 \cdot 90 \\
45 \cdot 54\end{array}$ & $\begin{array}{l}3333.03 \\
3322.18 \\
(10.35)\end{array}$ & $\begin{array}{r}454.01 \\
458.91 \\
4.90\end{array}$ & $\begin{array}{l}204.30 \\
186.97 \\
(17.33)\end{array}$ \\
\hline 2 & $\begin{array}{r}4325.23 \\
4452.46 \\
127.23\end{array}$ & $\begin{array}{l}3651.43 \\
3590.60 \\
(70.83)\end{array}$ & $\begin{array}{r}576.87 \\
583.23 \\
6.36\end{array}$ & $\begin{array}{c}217.75 \\
203.23 \\
(9.52)\end{array}$ \\
\hline 3 & $\begin{array}{r}3727.07 \\
3871.95 \\
144.38\end{array}$ & $\begin{array}{l}3463.54 \\
3371.25 \\
(92.29)\end{array}$ & $\begin{array}{l}439.49 \\
413.55 \\
(20.94)\end{array}$ & $\begin{array}{c}190.03 \\
136.91 \\
(3.12)\end{array}$ \\
\hline 4 & $\begin{array}{r}4391.96 \\
44.4 .45 \\
49.49\end{array}$ & $\begin{array}{c}3671.08 \\
3660.63 \\
(10.1+5)\end{array}$ & $\begin{array}{r}505.75 \\
522.10 \\
16.45\end{array}$ & $\begin{array}{r}211.60 \\
209.08 \\
(2.52)\end{array}$ \\
\hline
\end{tabular}

* Bracketed numbers mean that model gives this nuch less than plant. 


\begin{tabular}{|c|c|c|c|c|}
\hline CASE NO. & ETHYLBEN & STYREIVE & TOLUEME & 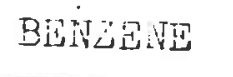 \\
\hline 5 & $\begin{array}{r}3449.44 \\
3651.09 \\
211.65\end{array}$ & $\begin{array}{l}3611.32 \\
3462.56 \\
(149.76)\end{array}$ & $\begin{array}{l}507.52 \\
485.55 \\
(21.97)\end{array}$ & $\begin{array}{l}251.81 \\
220.25 \\
(31.56)\end{array}$ \\
\hline 6 & $\begin{array}{r}3978.94 \\
4239.42 \\
260.28\end{array}$ & $\begin{array}{l}3933.33 \\
3751.75 \\
(181.58)\end{array}$ & $\begin{array}{r}575.44 \\
581.44 \\
6.00\end{array}$ & $\begin{array}{l}279.82 \\
240.55 \\
(39.27)\end{array}$ \\
\hline 7 & $\begin{array}{r}3409 \cdot 37 \\
3617.36 \\
207.99\end{array}$ & $\begin{array}{l}3633.59 \\
3512.65 \\
(120.94)\end{array}$ & $\begin{array}{l}518.75 \\
471.97 \\
(46.78)\end{array}$ & $\begin{array}{l}250.78 \\
226.10 \\
(24.63)\end{array}$ \\
\hline 8 & $\begin{array}{r}3802.32 \\
4232.98 \\
430.66\end{array}$ & $\begin{array}{l}4147.12 \\
3835.90 \\
(311.22)\end{array}$ & $\begin{array}{l}558.65 \\
498.09 \\
(60.56)\end{array}$ & $\begin{array}{l}239.44 \\
243.23 \\
(46.21)\end{array}$ \\
\hline 9 & $\begin{array}{l}3782.58 \\
3651.13 \\
(131.45)\end{array}$ & $\begin{array}{r}3229.90 \\
3367.60 \\
132.70\end{array}$ & $\begin{array}{c}509.58 \\
503.62 \\
(5.96)\end{array}$ & $\begin{array}{r}175.50 \\
209.90 \\
34.40\end{array}$ \\
\hline 10 & $\begin{array}{r}4367.98 \\
4357.61 \\
(10.37)\end{array}$ & $\begin{array}{r}3658.15 \\
3724.06 \\
65.91\end{array}$ & $\begin{array}{r}613.24 \\
621.21 \\
7.97\end{array}$ & $\begin{array}{r}222.43 \\
228.84 \\
6.41\end{array}$ \\
\hline 11 & $\begin{array}{r}3994.34 \\
4045.32 \\
50.98\end{array}$ & $\begin{array}{c}3557.71 \\
3508.59 \\
(49.02)\end{array}$ & $\begin{array}{r}547.02 \\
566.71 \\
19.69\end{array}$ & $\begin{array}{r}201.71 \\
212.44 \\
10.73\end{array}$ \\
\hline 12 & $\begin{array}{r}3965.56 \\
3979.54 \\
13.98\end{array}$ & $\begin{array}{c}3589.90 \\
3576.24 \\
(13.66)\end{array}$ & $\begin{array}{r}530.73 \\
549.66 \\
18.93\end{array}$ & $\begin{array}{r}206.49 \\
226.54 \\
20.05\end{array}$ \\
\hline 13 & $\begin{array}{l}4304.25 \\
4157.60 \\
(146.55)\end{array}$ & $\begin{array}{r}3229.83 \\
3449.88 \\
220.05\end{array}$ & $\begin{array}{r}516.25 \\
549.75 \\
33.50\end{array}$ & $\begin{array}{r}170.16 \\
186.85 \\
16.70\end{array}$ \\
\hline 14 & $\begin{array}{r}3798.31 \\
3997.17 \\
198.86\end{array}$ & $\begin{array}{c}3562.61 \\
3545.32 \\
(16.29)\end{array}$ & $\begin{array}{l}581.45 \\
572.60 \\
(8.85)\end{array}$ & $\begin{array}{l}229.13 \\
209.49 \\
(19.64)\end{array}$ \\
\hline 15 & $\begin{array}{c}4074.19 \\
4015.19 \\
(59.00)\end{array}$ & $\begin{array}{r}3452.24 \\
3538.38 \\
86.14\end{array}$ & $\begin{array}{r}563.07 \\
565.13 \\
2.06\end{array}$ & $\begin{array}{r}203.17 \\
214.21 \\
11.04\end{array}$ \\
\hline $1 \dot{A}$ & $\begin{array}{l}3962.79 \\
3840.27 \\
(122.52)\end{array}$ & $\begin{array}{r}3120.15 \\
3297.83 \\
177.73\end{array}$ & $\begin{array}{r}499.22 \\
529.86 \\
30.64\end{array}$ & $\begin{array}{r}169.77 \\
181.56 \\
11.79\end{array}$ \\
\hline
\end{tabular}




\begin{tabular}{|c|c|c|c|c|}
\hline CASE NO. & DTHYLBENZSNE & STYRENE & TOLUPNE & BEIVEN \\
\hline $2 A$ & $\begin{array}{r}4545.79 \\
4502.34 \\
(43.45)\end{array}$ & $\begin{array}{r}3551.56 \\
3617.33 \\
65.77\end{array}$ & $\begin{array}{r}493.15 \\
517.67 \\
24.52\end{array}$ & $\begin{array}{l}215.75 \\
197.98 \\
(17.77)\end{array}$ \\
\hline $3 n$ & $\begin{array}{l}4057.14 \\
3822.07 \\
(235.07)\end{array}$ & $\begin{array}{r}3037.83 \\
3344.65 \\
306.83\end{array}$ & $\begin{array}{r}480.31 \\
498.94 \\
18.63\end{array}$ & $\begin{array}{r}146.72 \\
183.87 \\
37.15\end{array}$ \\
\hline $4 A$ & $\begin{array}{l}3498.63 \\
3267.25 \\
(231.38)\end{array}$ & $\begin{array}{r}2759.75 \\
3046.91 \\
237.16\end{array}$ & $\begin{array}{l}401.85 \\
379.00 \\
(22.85)\end{array}$ & $\begin{array}{r}162.38 \\
172.52 \\
10.14\end{array}$ \\
\hline $5 \mathrm{~A}$ & $\begin{array}{c}3636.71 \\
3628.96 \\
(7.75)\end{array}$ & $\begin{array}{r}3346.86 \\
3434.73 \\
87.87\end{array}$ & $\begin{array}{r}538.74 \\
552.60 \\
13.86\end{array}$ & $\begin{array}{r}207.15 \\
214.82 \\
7.67\end{array}$ \\
\hline $6 \mathrm{~A}$ & $\begin{array}{r}4114.26 \\
4271.82 \\
157.56\end{array}$ & $\begin{array}{l}3871.20 \\
3768.04 \\
(103.16)\end{array}$ & $\begin{array}{l}554.79 \\
536.23 \\
(18.56)\end{array}$ & $\begin{array}{l}267.58 \\
236.47 \\
(31.11)\end{array}$ \\
\hline $7 \mathrm{~A}$ & $\begin{array}{r}3533.59 \\
3592.45 \\
58.86\end{array}$ & $\begin{array}{r}3427.80 \\
3489.15 \\
61.35\end{array}$ & $\begin{array}{l}549.81 \\
527.63 \\
(22.18)\end{array}$ & $\begin{array}{r}210.81 \\
220.09 \\
9.28\end{array}$ \\
\hline $8 A$ & $\begin{array}{r}4098.73 \\
4220.14 \\
121.41\end{array}$ & $\begin{array}{c}3921.52 \\
3828.17 \\
(93.35)\end{array}$ & $\begin{array}{l}561.74 \\
519.98 \\
(41.76)\end{array}$ & $\begin{array}{l}278.21 \\
242.15 \\
(36.06)\end{array}$ \\
\hline $9 \dot{A}$ & $\begin{array}{r}3616.56 \\
3633.61 \\
17.05\end{array}$ & $\begin{array}{r}3312.57 \\
3362.31 \\
49.74\end{array}$ & $\begin{array}{r}519.38 \\
535.76 \\
16.38\end{array}$ & $\begin{array}{r}139.42 \\
200.00 \\
10.58\end{array}$ \\
\hline $11 \mathrm{~A}$ & $\begin{array}{c}4075.86 \\
4039.03 \\
(37.83)\end{array}$ & $\begin{array}{r}3406.56 \\
3502.21 \\
95.62\end{array}$ & $\begin{array}{l}561.44 \\
582.13 \\
20.69\end{array}$ & $\begin{array}{r}199.51 \\
210.35 \\
10.84\end{array}$ \\
\hline $12 \dot{A}$ & $\begin{array}{r}3948.07 \\
3974.55 \\
26.48\end{array}$ & $\begin{array}{r}3502.56 \\
3577.82 \\
75.26\end{array}$ & $\begin{array}{r}561.19 \\
563.55 \\
2.36\end{array}$ & $\begin{array}{r}201.01 \\
215.21 \\
14.20\end{array}$ \\
\hline $13 \mathrm{~A}$ & $\begin{array}{r}4201.36 \\
4143.44 \\
(57.92)\end{array}$ & $\begin{array}{r}3338.17 \\
3449.76 \\
111.59\end{array}$ & $\begin{array}{r}530.12 \\
557.64 \\
27.52\end{array}$ & $\begin{array}{r}174.78 \\
193.51 \\
18.73\end{array}$ \\
\hline $15 A$ & $\begin{array}{r}3936.71 \\
4016.15 \\
79.44\end{array}$ & $\begin{array}{r}3534.38 \\
3537.34 \\
2.96\end{array}$ & $\begin{array}{c}564.74 \\
565.88 \\
2.14\end{array}$ & $\begin{array}{r}208.58 \\
212.52 \\
3.94\end{array}$ \\
\hline
\end{tabular}




\begin{tabular}{|c|c|c|c|c|}
\hline CASE NO. & ETFYLBEAZTNE & STYRENS & TOLUENE & BËZENE \\
\hline ID & $\begin{array}{c}3775.22 \\
33,88.41 \\
113.19\end{array}$ & $\begin{array}{c}3367.80 \\
3320.30 \\
(47.50)\end{array}$ & $\begin{array}{r}466.73 \\
470.57 \\
3.84\end{array}$ & $\begin{array}{l}195.12 \\
182.97 \\
(12.15)\end{array}$ \\
\hline
\end{tabular}

MEAN DEVIATION FOR 29 CASES RUN SEPARATELY RS ABOVE

\begin{tabular}{l|cccc} 
& $\begin{array}{c}\text { ITHYLBEHZWNE } \\
\text { LB./HR. }\end{array}$ & $\begin{array}{l}\text { STYFEINE } \\
\text { LB./HR. }\end{array}$ & $\begin{array}{l}\text { TOLUENE } \\
\text { LB./HR. }\end{array}$ & $\begin{array}{l}\text { BDNZENE } \\
\text { LB./HF. }\end{array}$ \\
\hline Deviation & 42.49 & 19.16 & 0.21 & (1.91)
\end{tabular}




\section{APPENDIX ? \\ MATRFIA BALATCE - 2 BED SITUETION WITH STEAM ADDITION BETWEDT BEDS}

\section{(1) FLON DIAGRIA (SITUATION 6iv, 2):}

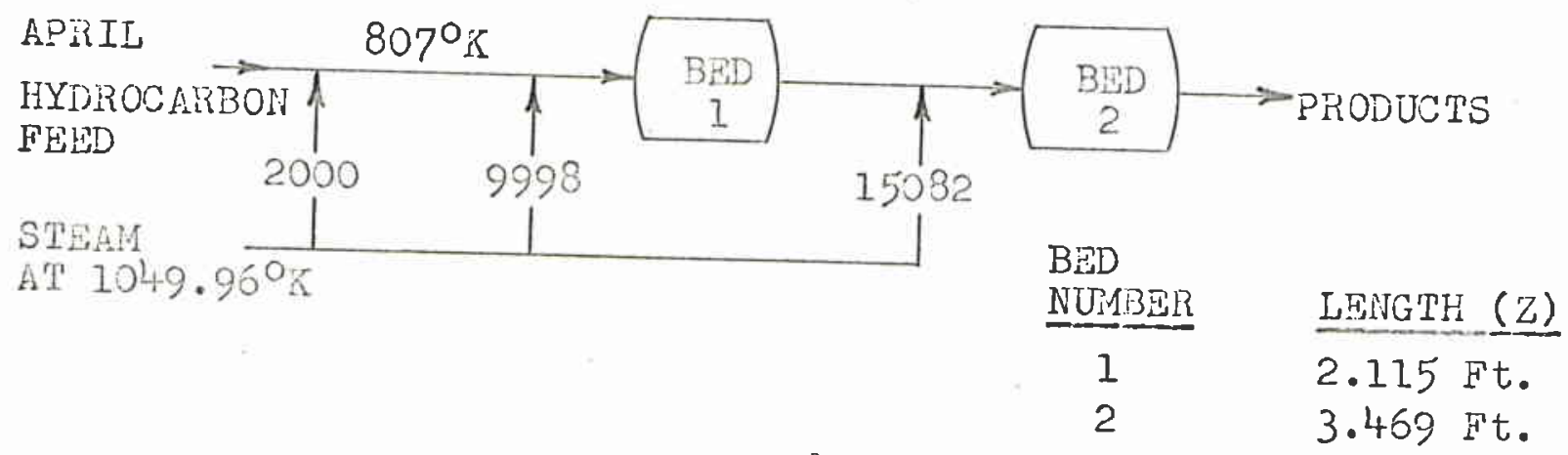

Note: Steam flows are in Lb./Hr.

(2) FEED BREA TDOWN:

\begin{tabular}{|c|c|c|c|c|}
\hline CORPOUND & $\begin{array}{l}\text { FESD RATE } \\
\text { (APRIL CASE) } \\
\text { LB./HR. }\end{array}$ & MODEL & $\begin{array}{l}\text { OPTIMUM PRODUCT RE } \\
L B . / \mathrm{HR} \text {. }\end{array}$ & RETE \\
\hline Ethylbenzene & 8630.73 & & 3817.06 & \\
\hline Styrene & 153.45 & & 4183.37 & \\
\hline Hyỏrogen & 0.0 & & 117.47 & \\
\hline Ethylene & 0.0 & & 26.55 & \\
\hline Benzene & 18.54 & & $323 \cdot 35$ & \\
\hline Toluene & 178.74 & & 431.56 & \\
\hline Me thane & 0.0 & & 25.69 & \\
\hline Ethane & 0.0 & & 0.0 & \\
\hline ficetylene & 0.0 & & 0.0 & \\
\hline Ethynylbenzene & 0.0 & & 0.0 & \\
\hline Stean & 27080.0 & & 26827.94 & \\
\hline Carbon Monoxide & 0.0 & & 2.87 & \\
\hline Carbon Dioxide & 0.0 & & 305.94 & \\
\hline Carbon & 0.0 & & 0.0 & \\
\hline
\end{tabular}


(3) REACTION CONVERSIONS:

\begin{tabular}{|c|c|}
\hline $\begin{array}{l}\text { REACTION } \\
\text { NUMBSR }\end{array}$ & $\begin{array}{l}\text { FINAL CONVEPION } \\
\text { Mole Fraction of Initial Reactant }\end{array}$ \\
\hline 1 & $.47598)$ \\
\hline 2 & ..ethylbenzene \\
\hline 3 & $.033754)$ \\
\hline 14 & $.0039293)$ \\
\hline 15 & $.00075934\} \ldots . .$. s team \\
\hline 16 & $.0046207)$ \\
\hline
\end{tabular}

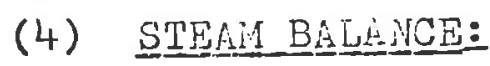

Steam in $=27080 \mathrm{Lb} . / \mathrm{Hr}$.

\begin{tabular}{c|c}
$\begin{array}{c}\text { REACTION } \\
\text { NUMBER }\end{array}$ & $\begin{array}{c}\text { WATER REACTED } \\
\text { LB./LR. }\end{array}$ \\
\hline 14 & $27080 \times .0039293=106.4 .35$ \\
15 & $27080 \times .00075934=20.563$ \\
16 & $27080 \times .0046207=\frac{125.129}{\Sigma}$ \\
& $\sum 252.097 \mathrm{Lb} . / \mathrm{Hr}$.
\end{tabular}

Stean leaving reactor $=27080-252.10=26827.90 \mathrm{Ib} . / \mathrm{Hr}$.

(5) ITHYLBDIZESE BALANCE:

Ethylbenzene in $=8630.73 \mathrm{Lb} . / \mathrm{Hr}$.

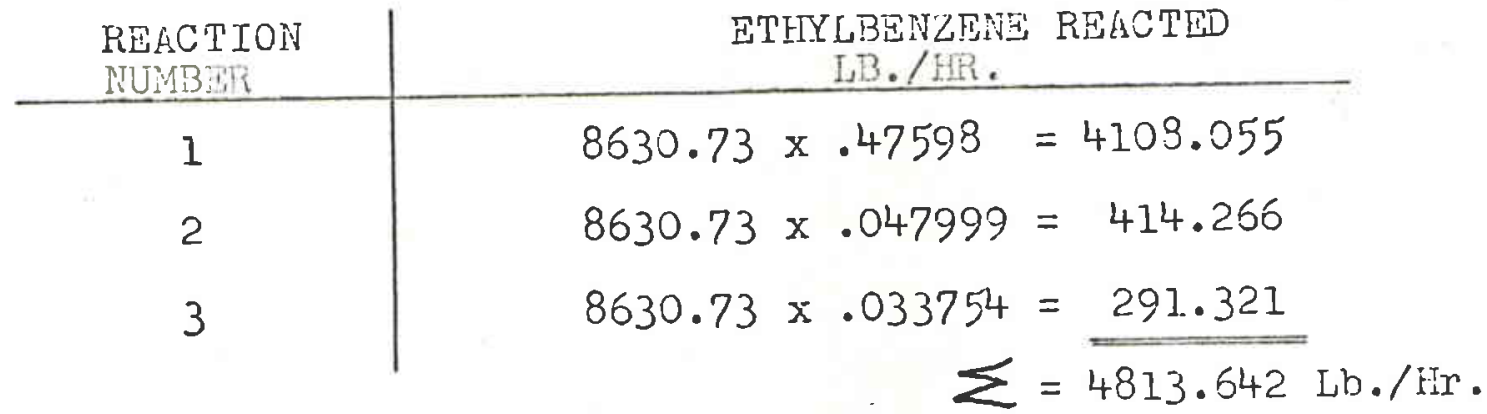

Ethylbenzene Unreacted $=3630.73-4813.64=3317.09 \mathrm{Lb} \cdot / \mathrm{Mr}$. 
(6) MAIN PRODUCTS

\begin{tabular}{|c|c|}
\hline $\begin{array}{l}\text { PRONUCT } \\
\text { NAMP }\end{array}$ & 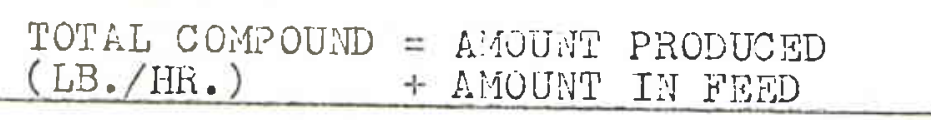 \\
\hline Styrene & $4108.055 \times \frac{104.14}{106.16}+153.45=41.33 .34$ \\
\hline Benzene & $414.266 \times \frac{78.11}{106.16}+18.54=323.35$ \\
\hline Toluene & $291.321 \times \frac{92.13}{106.16}+178.74=431.56$ \\
\hline
\end{tabular}




\section{A-PPEIDIX 8}

\section{DEVE}

\section{(1) EROMTIC RIVU COMPOUND VALUES:}

$$
\begin{aligned}
& \text { Styrene Gain/Ib. (w/Lb.) } \\
& =.105-\frac{106.15}{104.14} \times .06=+ \text { w.044/1b. styrene }
\end{aligned}
$$

Toluene Gain/lib.-(蓝/1…)

$=0.0185-\frac{106.16}{92.13} \times .06=-\$ .0508 / 1 b$. toluene

Benzene Gain/lo.. (

$=0.037-\frac{106.16}{78.11} \times .06=-\$ .0447 / 1 \mathrm{~b}$. benzene

Note: Unreacted ethylbenzene retains a value of $\$ \$ \$ .06 / 1 b$.

\begin{tabular}{|c|c|c|}
\hline COIPOUHD & $\begin{array}{l}\text { CALCULATION } \\
\text { B.T.U./LB. } \mathrm{x} \cdot 50 \times 10^{-6} \mathrm{~s} / \text { B.T.U. }\end{array}$ & $\begin{array}{l}\text { VALUE } \\
\text { P/LB. }\end{array}$ \\
\hline Hydrogen & $61,020 \times .50 \times 10^{-6}$ & .0305 \\
\hline Methane & $23,880 \times \cdot 50 \times 10^{-6}$ & .0119 \\
\hline Ethylene & $21,640 \times .50 \times 10^{-6}$ & .0108 \\
\hline
\end{tabular}

(2) FUEL GAS COMPOUND VALUSS:

Fience:

Gain $($ \$ $/ \mathrm{Hr})=.(\mathrm{Lb} \cdot / \mathrm{Hr}$. styrene $\mathrm{x} .044)-(\mathrm{Lb} \cdot / \mathrm{Hr}$. Toluene $\mathrm{x} .0508)$

$-\ldots . .+\left(\mathrm{Lb} \cdot / \mathrm{Hr} \cdot \mathrm{CH}_{4} \times 0.012\right)$

- Lb. steam/100 $(.0118+.0000646 \times \mathrm{T})$

where $\mathrm{T} \quad=$ Steam Tenperature $\left({ }^{{ }} \mathrm{K}\right)$

Values of B.T.U./Lb. calculated from Smith and Van Ness, Introduction to Chemical Engineering Thermodynamics, McGraw-
Hill, (1959) 


\section{APPENDIX 9}

\section{PEGRESSION EOUATION}

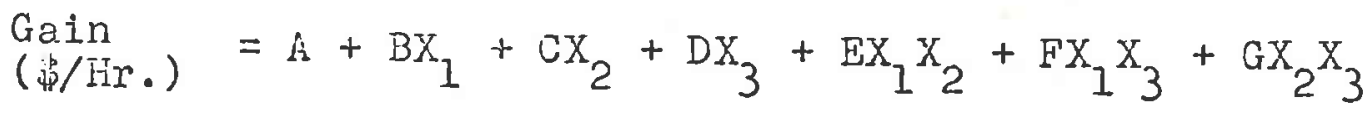

$$
\begin{aligned}
& +\mathrm{HX}_{1} \mathrm{X}_{2} \mathrm{X}_{3}+\mathrm{IX}_{1}^{2}+\mathrm{JX}_{2}^{2}+\mathrm{IX}_{3}^{2}+\mathrm{IX}_{1}{ }^{3}+\mathrm{MX}_{2}{ }^{3}+\mathrm{IX}_{3}{ }^{3}
\end{aligned}
$$

where:

$$
\begin{aligned}
& \mathrm{P}=\text { inlet pressure }=(1.046+.00122 \times \mathrm{S}) \text { Atmospheres } \\
& \mathrm{S}=\mathrm{Lb} \text {. Mols. Mixed Feed/Hr. } \\
& \mathrm{X}_{1}=\text { stean temperature... } \mathrm{O}_{\mathrm{K}} \\
& \mathrm{X}_{2}=\text { stearn rate....Lib/Hr. } \\
& \mathrm{x}_{3}=\operatorname{Bed} \text { depth.......t. } \\
& A=.20355438 \mathrm{EO} \\
& B=-.88456704 \mathrm{E} 01 \\
& C=.32631826 \mathrm{E}-01 \\
& D=.27360542 \mathrm{E} 02 \\
& \mathrm{E}=-.13250333 \mathrm{E}-04 \\
& \mathrm{~F}=.73207015 \mathrm{E}-02 \\
& G=.37359278 \mathrm{E}-02 \\
& \mathrm{H}=-.35742527 \mathrm{E}-05 \\
& I=.10436194 \mathrm{E}-01 \\
& J=-.85542770 \text { E-06 } \\
& K=-.42597412 \mathrm{E} \mathrm{Ol} \\
& L=-.37617352 \text { E-05 } \\
& 11=.12390612 \mathrm{i}-10 \\
& \mathrm{~N}=.16721005 \mathrm{E} 00
\end{aligned}
$$

(Standard Error of Estimate) ${ }^{2}=17.58$ on 111 degrees of freedom 
APPEIDIX_10

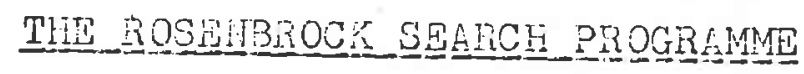

(1) Exnlaination of Major Terms

Niv.... Number of variables to be searched

X.....Variable nánes

A.....Accelerating factor $A>1.0$

BB....Decelerating factor $-1<B B<0$

C..... Initial perturbation of variable

R.....Storage of variable values at beginning of each stage

U......Current value of perturbation of a variable

F..... Counts failures in search when search is parallel and perpendicular to axii

G..... Counts failures in search when search may be in any direction. In $G$ and $F$ when we register at least $I$ failure per variable we cone to the end of a stage.

L...... Exit from stage failure register.

MM.... Successive failure counter; if $M M=N N$, the search is returned to being parallel and perpendicular to the axii. (i. e. This is used for constraints of the type $X<X M$ ).

Y2.... Current response of $X$, $i$. e. in the progranme we minimize $\mathrm{Y} 2$ where $\mathrm{Y2}=1 / \mathrm{HR}$ GAIN where $\mathrm{HR}$ GeII is the hourly gain we wish to maxinize.

Y1... The best response to date. The progremme stores the values of $\mathrm{X}(\mathrm{I})$ giving the optimun response $\mathrm{Yl}$. By mininizing $\mathrm{YI}$ we maximize the GAII in $\$ \mathrm{H} / \mathrm{Hr}$.

Lut... Then the condition, i. e. A3S (Y2 - Y1) < (sone preset tolerance) has been met LIL times, we can stop the search.

K.....directs what sections of the programe are active. 


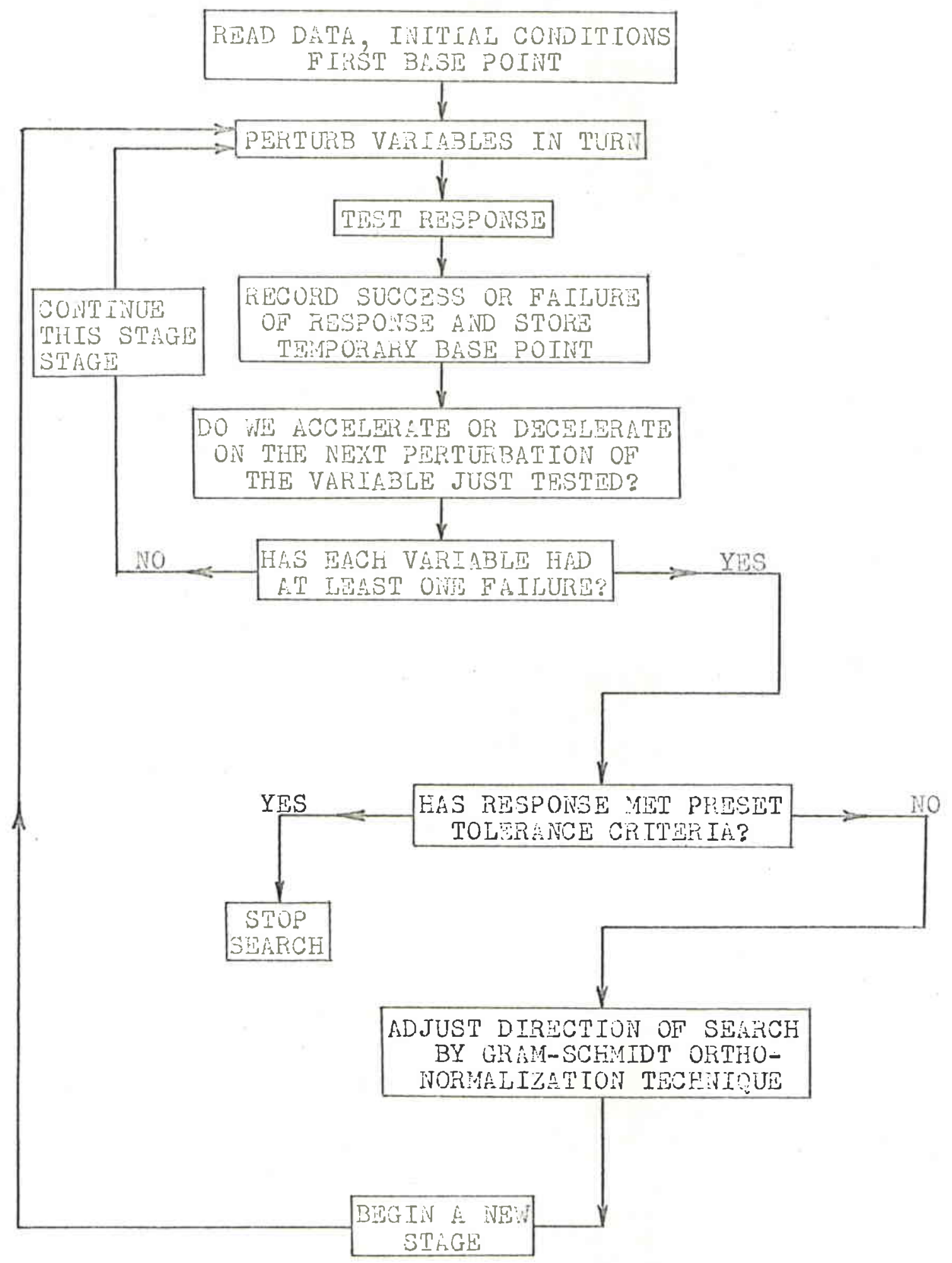




\section{APPEND IX 11}

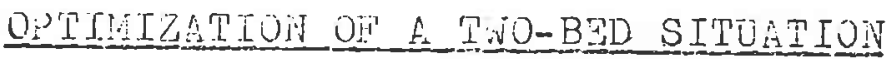

The following programe combines the Rosenbrock Search with a two-bed inodel. Five variables (Stean temperature, Steain flow rates to beds 1 and 2 and the depths of Beds 1 and 2) are being searched with the goal of maxinizing the GAIN FUUTCION ( $/$ /HR). The situation being studied is like situation $6 i$ of Appendices 12 and 13 .

Note that sone array names had to be changed when the model was combined with the Rosenbrock Search projranine. For example, the $A(I)$ of the single beo model of Appendix 5 is now $W(I), C(I)$ is now $V(I)$ and so on. 


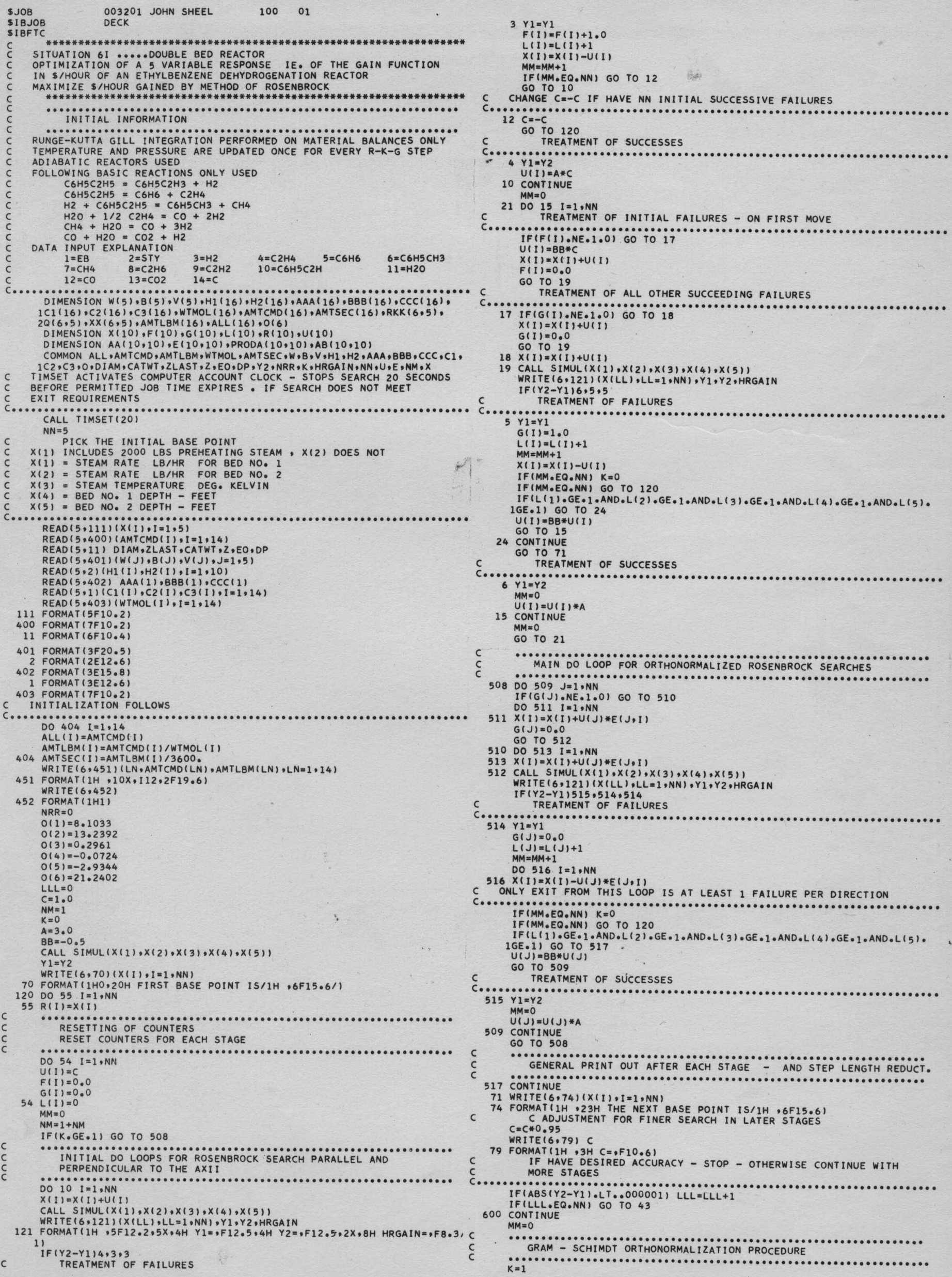




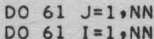

$A A(J, I)=X(I)-R(I)$

61 CONTINUE

$\mathrm{I}=1$

DO $62 \quad J=2, N N$

$A A(J, 1)=0.0$

$\mathrm{I}=\mathrm{I}+1$

IF (I.EQ.NN) GO TO 63

DO $62 \mathrm{KK}=1$, NN

$A A(J+1, K K)=A A(J, K K)$

62 CONTINUE

3 CONTINUE
SUMSQS $=0.0$

DO $64 \quad I=1, N N$

64 SUMSQS $=A A(1,1) * * 2+$ SUMSQS

DO $65 \quad I=1, N N$ ) SORT (SUMSQS )

$65 \mathrm{~J}=2$

76 SUM $=0.0$

DO $66 \quad \mathrm{I}=1$, NN

$P R O D=A A(J, I) * E(J-1, I)$

66 SUM $=P R O D+S U M$

67 PRODA $(J, I)=S U M * E(J-1, I$

DO $68 \mathrm{I}=1$, NN

68 AB(J,I)=AA(J, I )-PRODA (J, I)

SUMT $=0.0$

DO $69 \mathrm{I}=1$, NN

69 SUMT $=A B(\mathrm{~J}, \mathrm{I})$ **2+SUMT

500 E(jol)=AB(j)

(SUMT)

$J=J+1$

$J=J+1$
GO TO 76

501 CONTINUE

WRITE $(6,700)$

700 FORMATIIHO, $18 \mathrm{H}$ END OF THIS STAGE/1HO GO TO 120

C PROGRAMME EXIT IF HAVE DESIRED ACCURACY

$43 \mathrm{NM}=\mathrm{NM}-1$

601 WRITE $(6,122) \mathrm{NM}, \mathrm{Y} 1, \mathrm{Y} 2$

122 FORMAT $(1 \mathrm{H}, 3 \mathrm{H} \mathrm{N}=, 110,4 \mathrm{H} Y 1=, F 12,7,4 \mathrm{H} Y 2=, F 12.7)$ WRITE $(6,121)(X(L L), L L=1, N N), Y 1, Y 2, H R G A I N$ STOP

$c$
$C$
$C$
$C$

SIBFTC SIMUL

SUBROUT INE SIMUL IRAT 1,RAT2, TSTEAM, Z1LAST, 22LAST

年,

IC1 16 )

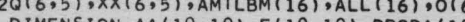

$0,10), A B(10,10)$

DIMENSION $X(10), F(10), G(10), L(10), R(10), U(10)$

COMMON ALL, AMTCMD, AMTLBM, WTMOL, AMTSEC, $W, B, V, H 1, H 2, A A A, B B B, C C C, C 1$,

$1 C 2, C 3, O, D I A M, C A T W T, Z L A S T, Z, E O, D P, Y 2, N R R, K$, HRGAIN, NN, $U, E, N M, X$
TIMTST STOPS PROGRAMME IF

C...

CALL TIMTSTIIUIU

IF (IU.LT.O)STOP

$211=$ ZILAST

$222=22 L A S T$

DREW1 $=$ RAT 1
DREW2 $=$ RAT2

C HIGH RESPONSE FOR CASE WHERE X(I) EXCEEDS ITS CONSTRAINT

NRN $=0$

IF $(X(1), L T \cdot 0.0)$ NRN $=1$

IF $(X(2) \cdot . L T \cdot 0.0) \quad N R N=1$

IF ( X ( 3$\left.) \cdot . L T \cdot 1000 \ldots R_{\bullet} X(3), G T \cdot 1050.0\right) \quad N R N=1$

IFIZILAST.LT.0.0.OR.ZILAST.GT.558.33) NRN=1

IF (Z2LAST.LT, 0.0.OR.ZZLAST.GT.558.33) NRN $=$

IF (NRN.EQ.1) GO TO 800

C MIRROR IMAGE CONSTRAINT TREATMENT FOR STEAM RATE

C IE. $(x(1))+x(2)), \cdot L T, 18000$. LB/HR

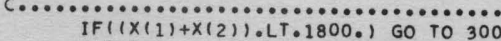

RAT $11=x(1)-(x(1)+x(2)-1800,1$

RAT $22=x(2)-(x(1)+x(2)-1800$.

IF (RAT 11.LT 0.0 ) RAT $11=100$.

IFIRAT 22.LT 00.0 ) RAT $22=100$ 。

RAT $1=$ RAT 11

RAT $2=$ RAT 22

300 CONTINU

C REMOVE SCALING FACTORS ON VARIABLES

AMTCMDIII)=RATH*10.

Z1LAST $=21$ LAST $/ 100$
$Z 2 L A S T=22 L A S T / 100$

MIRROR IMAGE CONSTRAINT TREATMENT FOR BED DEPTHS

C IE. $(Z 1+Z 2) \cdot L T \cdot 5.5833 \mathrm{FEE}$

IF( (ZILAST+Z2LAST),$L T \cdot 5.5833)$ GO TO 30

Z1LA $=21 L A S T-(21 L A S T+Z 2 L A S T-5.5833)$
$Z 2 L A=Z 2 L A S T-(2)$

IF (ZILA.LT.0.0) Z1LA $=0$.

ZILAST $=$ ZILA

301 CONTINUE

CONTINUE

AMTSEC(11) = ALL (11)/(3600. *WTMOL (111)

C COUNTER NRR IS USED SO THAT THIS IS SET ONLY ONCE

IFINRR.GT, 1 ) GO TO 717

NRCT $=6$

$N=14$

AREA $=3.1416 *(\mathrm{DIAM} / 2,1) * 2$

VISC $=0.03 * 6.72 * 1.0 E-04$
$E F F=A R E A * C A T W$

$E E L=E O * E O * E O$

OFE $=144 * * 14,7 * 32.2$

FSTYO $=$ AMTSEC (2)

FH2O $=A M T S E C(3)$

FC2 = AMTSEC(3)

$F C 2 H 4 O=A M T S E C(14)$
$F B Z O=A M T S E C(5)$

FTOLO =AMTSEC (6)

FCH4O=AMTSEC ( 17$)$

FC2H6O=AMTSEC $(8)$

FC2H2O=AMTSEC( 9$)$

FRC2 $H O=A M T S E C(10)$

$F C O O=A M T S E C(12)$

FCO2O $=$ AMTSEC $(13)$

FCO $=$ AMTSEC (14)

717 CONTINUE

DO $33 \mathrm{M}=1$, NRC

$X X(M, 1)=0.0$

33 Q $R$ (M, $(M)=0.0$

33 RKK $(M, 1)$

NBED $=1$ =

SUMMLS $=0.0$

DO $22 \quad M=1, N$

22 SUMMLS $=$ SUMMLS S+AMTSEC $(M)$

SUMIN $=$ SUMMLS-FEBO

IF (NBED.NE,1) GO TO 821

TI $N=0.0$

MIX CALCULATES MIXED FEED TEMPERATURE

,RAT 2, NBED I

C CORRECT INTEGRATION STEP SIZE DETERMINATION

NSTEP $=75$

IF(TIN.LT.985.) NSTEP $=50$

IFITIN.LT.960, NSTEP $=25$

IF (TIN.LT.960..AND.AMTCMD(11),GT •22000, ) NSTEP=NSTEP*

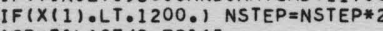

$A O R=Z 1 L A S T / 2.79165$

ANTT=FLOATINSTEPI*

ANTEP=IFIX(ANIT)

21 CONTINUE

IF (NBED.NE.2) GO TO 820

IF INBED

C TMIX CALCULATES MIXED FEED TEMPERATURE

C.........................................

CORRECT INTEGRATION STEP SIZE DETERMINATION

NSTEP $=75$

IF ( TIN.LT.985.) NSTEP $=50$

IF(TIN.LT.960.) NSTEP $=2$

.) NSTEP $=$ NSTEP*

IF $(1 X(1)+X(2)) \cdot L T \cdot 1200$.) NSTEP $=$ NSTEP*2

$A O R=22 L A S T / 2.79165$

ANI T $=$ FLOAT (NSTEP) *AOR

NSTEP $=$ IFI $X$ IANIT

H=Z2LAST/FLOAT INSTEP

FH2OO=FH2OO+RAT $2 * 10 . /(3600$ *WTMOL (11)

AMTSEC $(11)=$ AMTSEC $(11)+R A T 2 * 10.1(3600 * * W T M O L(11))$ SUMML $S=0.0$

SUMMLS $=$ SUMMLS+AMTSEC $(M)$

SUMIN $=$ SUMMLS-FEBO

820 CONTINUE

AVML WT $=0.0$

DO $24 \quad M=1, N$

24 AVMLWT $=A V M L W T+W T M O L(M) * A M T S E C(M) /$ SUMMLS

DENGAS $=P$ IN*AVMLWT $/(1.314 *$ T IN)

VO=SUMMLS* (TIN*359./1273**PIN) )/AREA

IF (NBED.EQ.2) GO TO 837

WRITE 16,44

44 FORMAT $11 \mathrm{H}, 3 \mathrm{X}, 7 \mathrm{H}$ LENGTH, $8 \mathrm{X}, 6 \mathrm{H}$ TEMP $, 8 \mathrm{X}, 6 \mathrm{H}$ PRES $, 8 \mathrm{X}, 6 \mathrm{H} \times 1$, $8 \mathrm{X}$, $16 \mathrm{H} \times 2,8 \times$

837 CONTINUE

WRITE $(6,454) Z, T I N, P I N,(X X(L O, 1), L O=1, N R C T)$

454 FORMAT 11 , $9 E 14.5$

C*****1.

C PLEASE REFER TO SECTION 5 IN APPENDIX FOR DETAIL OF INTEGRATION

DO 7 NSEC $=1$, NSTEP

$R S T=($ AAA $(1) / T I N+B B B(1)+C C C(1) * T I N) * 1000 \cdot 11 \cdot 987$

$S S T=E X P(-R S T)$

FACES =EFF

EXI $=E X P(-10925 . / T I N+0(1))$

$E \times 2=E X P(-25000 . / T 1 N+0(2)$,

EX3 $=\operatorname{EXP}(-11000 . / T I N+O(3)$

EX $4=\operatorname{EXP}(-12500,1 T I N+0(4)$

EXS
EXXP(-8850.0

EX6 $=E X P(-8850.01 T I N+O$
DX6

DO $100 \quad M=2,5$

$M 1=M-1$

PEB =FEBO* $(1,-x x(1, M 1)-x \times(2, M 1)-x x(3, M 1))$

PSTY $=F E B O * X X(1, M 1)+F S T Y O$

$P C O=F H 2 O O *(X X(4, M 1)+X X(5, M 1)-X X(6, M 1))+F C O O$

$P \mathrm{CO} 2=F \mathrm{H} 2 \mathrm{OO} * X \times(6, \mathrm{M} 1)+\mathrm{FCO} 20$

$P H 2 O=F H 200 *(1,-X X(4, M 1)-X X(5, M 1)-X x(6, M 1))$

$P C H 4=F E B O * X X(3, M 1)+F C H 40-F H 2 O O * X X(5, M 1$

$P C_{2} H_{4}=F E B O * X X(2, M 1)+F C 2 H 4 O-F H 2 O O * 0.5 * X X(4, M 1)$

$P H 2=F E B O *(X X(1, M 1)-X X(3, M 1))+F H 2 O+F H 2 O O *(3, * x X(5, M 1)+X X(6, M 1)+$

$12.0 * X X(4, M 1)$

PTOTAL $=F E B O *(1,+X X(1, M 1)+X X(2, M 1))+S U M I N+F H 2 O O *(2, * X X(5, M 1)+$

$11.5 * X X(4, M 111$
POST $=$ PIN INTOTAL

RKK $(1, M)=F A C E B * E X 1 * P O S T *(P E B-P S T Y * P H 2 * P O S T / S S T) / 3600$.
$R K K(2, M)=F A C E B * E 2 * P E B * P O S T$

RKK $(3, M)=F A C E B * E X 3 * P E B * P H 2 * P O S T * P O S T$

RKK $(4, M)=F A C S T * E X 4 * P H 2 O * S Q R T(P C 2 H 4 * P O S T) * P O S T$

RKK $(5, M)=F A C S T * E X 5 * P C H 4 * P O S T$

RKK $(6, M)=E X 66 * F A C S T * E X 6 * P H 2 O * P C O * P O S T * P O S T$ 
$D 092, I S=1, N R C T$
$X X(I S, M)=X X(I S, M 1)+H *(W(M) *(R K K(I S, M)-B(M) * Q(I S, M 1)))$

$92 Q(I S, M)=Q(I S, M 1)+3.0 *(W(M) *(R K K(I S, M)-B(M) * Q(I S, M I)))-V(M) * R K K(I S$,

100 CONTINUE

HEAT I $N=0.0$

DO $56 \mathrm{M}=1, \mathrm{~N}$

56 HEATIN=HEATIN+1.8*AMTSEC $(M) *\left(C_{1}(M)+C 2(M) * T I N+C 3(M) * T I N * T I N\right)$ AMTSEC $(1)=F E B O *(1,0-X X(1,5)-X X(2,5)-X X(3,5))$

AMTSEC ( 2$)=F E B O * X X(1,5)+F S T Y O$

AMTSEC ( 3$)=F E B O *(X X(1,5)-X X(3,5))+F H 2 O+F H 2 O O *(3, * X X(5,5)+X X(6,5)+$

AMTSEC $(4)=F E B O * X X(2,5)+F C 2 H 40-F H 2 O O * 0.5 * x \times(4,5)$

AMTSEC (6) $(6)=F B O \times X(3,5)+F$ CO

AMTSEC $(6)=F E B O * X X(3,5)+F T O L O$
AMTSEC $(7)=F E B O * X X(3,5)+F C H 4 O-F H 2 O O * X X(5,5)$

AMTSEC $(11)=F H 2 O 0 *(1,-X X(4,5)-X X(5,5)-X X(6,5))$

AMTSEC $(12)=F H 2 O O *(X X(5,5)-X X(6,5)+X X(4,5))+F C O O$

AMTSEC (13) $=F$ F $200 * X X(6,5)+F C O 2 O$

SUMMLS $=0.0$

50 SUMML $S=S U M M L S+A M T S E C$ CM

HEATRX $=0.0$

DO $57 \mathrm{M}=1,3$

7 HEATRX $=H E A T R X+1.8 *(X X(M, 5)-X X(M, 1)) * F E B O *(H 1(M)+H 2(M) * T I N$

691 HEATRX $=$ HEATRX+1.8*(XX(M+3,5) $-X X(M+3,1)) * F H 2 O O *(H 1(M+3)+H 2(M+3) *$ TIN 1)

$T$ IN $=$ TIN-HEATRX/HEATIN

$D P T=V O *(1,-E O) /(E E L * D P) *(150 *$ VISC*(1,-EO)/DP+1 $75 *$ VO*DENGAS)

$1 /$ OFE*H

PIN $=P I N-D P T$

AVMLWT $=0.0$

34 AVMLLT $=A V M L W T+W T M O L(M) * A M T S E C(M) /$ SUMMLS

DENGAS $=$ PIN*AVMLWT/(1.314*TIN)

VO=SUMMLS*(TIN*359.1(273.*PIN))/AREA

DO $97 \mathrm{M}=1$, NRCT

$X X(M, 1)=X X(M, 5)$

$97 Q(M, 1)=Q(M, 5)$

$Z=F L O A T(N S$

7 CONTINUE

WRITE $(6,454) Z, T I N, P I N,(X X(L O, 1), L O=1, N R C T)$

C ADJUST FOR STEAM ADDITION BETWEEN BEDS

IF INBED.NE. 1 ) GO TO 678

NBED $=2$

$\mathrm{Z}=0.0$

DO $822 \mathrm{M}=1$, NRCT

822 RKK $(M, 1)=0.0$

STRRAT $=$ RAT $1 /($ RAT $1+R A T 2)$

DO $823 M=4,6$

$823 x X(M, 1)=X X(M, 5) *$ STRRAT

$G O$ TO 821

DO $66 \quad M=1$, N

AMTLBM $(M)=A M T S E C(M) * 3600$

66 AMTCMD $(M)=A M T L B M(M) * W T M O L(M)$

C

1ON

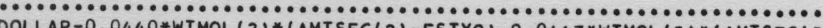

1) $-F B Z 0)-0.4$ (

1)-FB20) 0.0508 *WTMOL (6) *(AMTSEC (6) -FTOLO) $-F H 200 / 100$ *WTMOL (11)*

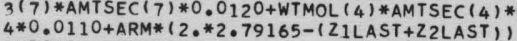

HRGAIN $=$ DOLLAR* 3600 . $Y 2=1.0 /$ IHRGAIN

WRITE $(6,457)$ HRGAIN, Y2

457 FORMAT $\left(1 \mathrm{H} / 21 \mathrm{X}, 13 \mathrm{H}\right.$ DOLLARS/HR $\left.=, \mathrm{F} 10.2,3 \mathrm{X}, 5 \mathrm{H} Y_{2}=, \mathrm{F} 10.7\right)$

WRITE $(6,451)(A M T C M D(L N), L N=1,14)$

451 FORMAT $(1 \mathrm{H}, 20 \mathrm{X}, 7 \mathrm{~F} 15.3$

DO $112 M=1, N$

AMTSEC $(M)=A L L(M) /(3600 . * W T M O L(M))$

12 AMTCMD $Z$ T

ZILAST $=Z 11$

Z2LAST $=222$

RAT $1=$ DREW1
RAT2 $=$ DREW2

800 CONTINUE

RETURN

$\mathrm{C}$
$\mathrm{C}$
$\mathrm{C}$
$\mathrm{C}$
\$I B

SIBFTC TMIX

SUBROUT INE TMIX(TIN, TSTEAM, RAT1, RAT2, NBED)

PROGRAMME GIVES TEMP OF MIXED STREAM FROM UP

5 STREAMS 14 COMPONENTS EACH

ENTER TSTRM IN DEG $K \ldots . . C_{1}, C_{2}$, AND C3 ARE COEFFS OF

$A+B T+C T * * 2 \ldots(T=$ DEG $K)$ AND UNITS ARE BTU/LBMOL*DEG

ENTER ALL 14 COMPS/STREAM(1) IN ROW AND FOLLOW WITH 14

COMPS OF STREAM(2) ...ETC

DIMENSION STRCMD $(140)$, TSTRM $(5)$, STRMOL $(140)$, HEAT $(5)$, TOCOMO 14

1, AMTCMD (16), WTMOL $(16), C 1(16), C 2(16), C 3(16)$, STOR $(140$

2, ALL (16), AMTLBM (16), AMTSEC (16), O (6), W(5), B $(5), V(5), H 1(16), H 2(16)$

DAAA(16), BBB (16), CCC(16)

DIMENSION $X(10), F(10), 10,10), P R O D A(10,10), A B(10,10)$

DIMENSION $X(10), F(10), G(10), L(10), R(10), U(10)$

$1 C 2, C 3, O, D$, IAM, CATWT, ZLAST, $Z, E O, D P, Y 2, N R R, K, H R G A 1, H 2, A A A, B B B, C C C, C 1$,

$\begin{aligned} \text { NSTRM } & =2 \\ \text { NCOMP } & =14\end{aligned}$

NR=NSTRM*NCOMP

TSTRM $(1)=$ TSTEAM

IF (NRR.GT.0) GO TO 688

650 FORMAT $(7 F 10.2)$

DO $683 \mathrm{NI}=1$, NR

683 STOR (NI) $=S T R C M D(N I$

\section{$N R R=N R R+1$}

IF (NBED.NE.1) GO TO 675

$\operatorname{TSTRM}(2)=807.0$

DO $684 \quad N I=1, N R$
STRCMD (NI) $=S T O R(N I)$

C STEAM RATE TO FIRST BED LESS 2000 . LB/HR ALREADY MIXED

C WITH HY

STRCMDIIi) $=$ RATI*10.-2000.

675 CONTINUE

IF (NBED.NE.2) GO TO 685

$\operatorname{TSTRM}(2)=\operatorname{TIN}$

DO $682 \mathrm{NI}=1$, NCOMP

AMTCMD (NI) $=A M T S E C(N I) * W T M O L(N I) * 3600$

$\operatorname{STRCMD}(N I)=S T O R(N I)$

$\mathrm{NJ}=\mathrm{NI}+14$

C STEAM RATE TO SECOND BED

STRCMDiij) $=$ RAT2* 30 .

685 CONTINUE

$N K=0$

654 DO 653 NA $=1$, NCOMP

$\mathrm{NO}=\mathrm{NA}+\mathrm{NK}$

$653 \operatorname{STRMOL}(N O)=S T R C M D(N O) / W T M O L$ (NA)

$N K=N K+N C O M P$

IF (NK•EQ.NR) GO TO 681

GO TO 654

$681 N C=0$

655 DO 656 NI $=1$, NSTRM

HEAT $(N I)=0.0$

DO 657 NB $=1$, NCOMP

$N S=N B+N C$

$657 \operatorname{HEAT}(N I)=\operatorname{HEAT}(N I)+S T R M O L(N S) *\left(C_{1}(N B)+C_{2}(N B) * T S T R M(N I)+C_{3}(N B) *\right.$ 1 TSTRM (NI)*TSTRM (NI) $) *(1.8 *(T S T R M(N I)-273.1)+32$.

IF(NC.EQ.NR) GO TO 658

C TO HERE HAVE ENTHALPIES OF EACH STREAM

658 HTTOT $=0.0$

DO $659 \mathrm{NI}=1$, NSTRM

659 HTTOT $=$ HTTOT + HEAT (NII

C NOW NEED TOTAL MOLES EACH COMP IN MIXED STREAM

DO 661 NI $=1$, NCOMP

661 TOCOMO(NI) $=0.0$

$\mathrm{ND}=0$

664 DO $662 \mathrm{NI}=1$, NCOMP

$\mathrm{NZ}=\mathrm{NI}+\mathrm{ND}$

662 TOCOMO (NI) $=$ TOCOMO $(N I)+S T R M O L(N Z)$

$N D=N D+N C O M P$

IF (ND.EQ.NR) GO TO 663

GO TO 664

C TO HERE HAVE ALL MOLES COMP I FROM ALL STREAMS IN TOCOMO(I)

C NEWTON-RAPHSON METHOD FOR SOLVING FOR TOUT OR TEMP OF MIXED FEED

TOUT $=$ TSTRM 1

667 HTNWRN $=0.0$

DO $665 \mathrm{NI}=1$, NCOMP

665 HTNWRN $=H T N W R N+T O C O M O(N I) *(C 1(N I)+C 2(N I) * T O U T+C 3(N I) *$ TOUT *TOUT $)$ * $1(1.8 *($ TOUT -273.1$)+32$.

DELT $=$ TOUT +.001

DELHT $=0.0$
DO $666 \quad \mathrm{NI}=1$, NCOMP

666 DELHT =DELHT+TOCOMO $(N I) *(C 1(N I)+C 2(N I) * D E L T+C 3(N I) * D E L T * D E L T) *$

C USE SIMILAR TRIANGLES RULE TO GET TOUT NEXT

TNEXT $=$ TOUT $-($ DELT-TOUT) $*$ (HTNWRN-HTTOT) $/$ DELHT-HTNWRN TOUT $=$ TNEXT

668 CONTINUE

TIN=TOUT

RETURN

END

SENTRY

$\begin{array}{lllll}903.80 & 1552.80 & 1124.72 & 174.00 & 384.10\end{array}$

$\begin{array}{rrrrrr}8630.73 & 153.45 & 0.00 & 174.00 & 384.10 & \\ 0.00 & 0.00 & 0.00 & 0.00 & 18.54 & 178.74\end{array}$

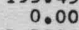

5.5833

134.0

.50000

.29289

1.70711

.288430 E OS .109000 E 01

.259920E 05-.190000E OI

-.127020 E 05-.315000E O1

$.196020 E$ O5 .211000E OI

-.50460E O5 .396000 E 01

.000000 E 00.250000 E 01

. OOONOOE OO 00.000000 E OO

.000000E 00.000000E 00

.000000 E 00 .000000E 00

$0.29310942 E \quad 02-0.30157089 E-01-0.52385439 E-06$

$.223000 E$ O1 .110000E 00-.367000E-04

.407000 E 01.097700 E OO-.331000E-04

$.694700 E$ 01-.200000E-03 .481000E-06

.283000E $01.286010 E-01-.872600 E-05$

$-.409000 E$ O1 $.776210 E-01-.264260 E-04$

.576000E $.934930 \mathrm{E}-01-.312270 \mathrm{E}-04$

$.338100 E$ E $01.180440 E-01-.430000 E-05$

$.224700 E$ E $1382010 E-01-.110490 E-04$

.347000 E $01.126220 \mathrm{E}-01-.388900 \mathrm{E}-05$

.725600 E $01.919000 \mathrm{E}-01-.314000 \mathrm{E}-04$

.642000 E $01.22900 E-02.283000 E-06$

.642000 E $01.166500 \mathrm{E}-02-.196000 \mathrm{E}-06$

$.410000 \mathrm{E} 01.102000 \mathrm{E}-02$. $354500 \mathrm{C}-0 \mathrm{~S}$ 


$\begin{array}{rrrrrrr}106.16 & 104.14 & 2.02 & 28.05 & 78.11 & 92.13 & 16.04 \\ 30.07 & 26.00 & 102.00 & 18.00 & 28.01 & 44.01 & 12.00 \\ 0.00 & 0.00 & 0.00 & 0.00 & 0.00 & 0.00 & 0.00 \\ 0.00 & 0.00 & 0.00 & 0.00 & 0.00 & 0.00 & 0.00 \\ 8630.73 & 153.45 & 0.00 & 0.00 & 18.54 & 178.74 & 0.00 \\ 0.00 & 0.00 & 0.00 & 2000.00 & 0.00 & 0.00 & 0.00 \\ \text { SIBSYS } & & & & & & \end{array}$




$$
\begin{aligned}
& \text { APPPID IX } 12 \\
& \text { ROEPRBPOOS SEARCHES } \\
& \text { Legend: } \quad T=\text { Steam temperature.......... } \mathrm{O}_{\mathrm{K}} \\
& \text { S.R. }=\text { Stean flow rate............Lb./Hr. } \\
& Z=\text { Bed depth.................. } \\
& P=\text { Inlet pressure..............tnos. } \\
& \text { S.K.I = Steam flow rate to bed I....L. L./FIr. } \\
& \text { S.R.2 = steam flow rate to bed } 2 \ldots \text {. Lb./Fir. }
\end{aligned}
$$

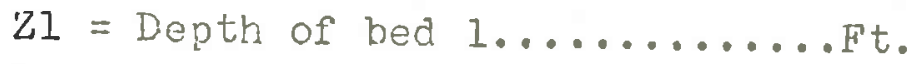

$$
\begin{aligned}
& Z 2=\text { Depth of bed } 2 \ldots \ldots \ldots \ldots . . . . . \text {. . . }
\end{aligned}
$$

\section{REF.\# REIPEREHCES TO ROSEIBROCK SEAECHES}

A The standard April case is included in the other cases for comparison with extrcpolited model results.

B Only $z$ was varied here.

C The failure of the cost function becomes apparent bere. There is a saddle point somewhere between the two gains or the cost function is inadequate (see 6.2).

D The search was conducted along S.R.I + S.R.2 constraint, i.e.S.R. I was varied and S.R.2 was set equal to $(18000-$ S.R.I). Hence this is a search in one less variable.

E The search was concluded early so that it may be used for comparison with other runs of the sane situation.

F The (S.R.I + S.R.2 S total steam flow) constraint was handled by the mirror inage method. I.e. both S.R.I and S.R.2 were variables.

$G$ The search was terminated after 20 minutes due to very slow prozress or because it is at a false optimum.

$\mathrm{H}$ These cases are reruns of $3 i i-1,2,3$ but with a smaller step size in the integration. 
$-125-$

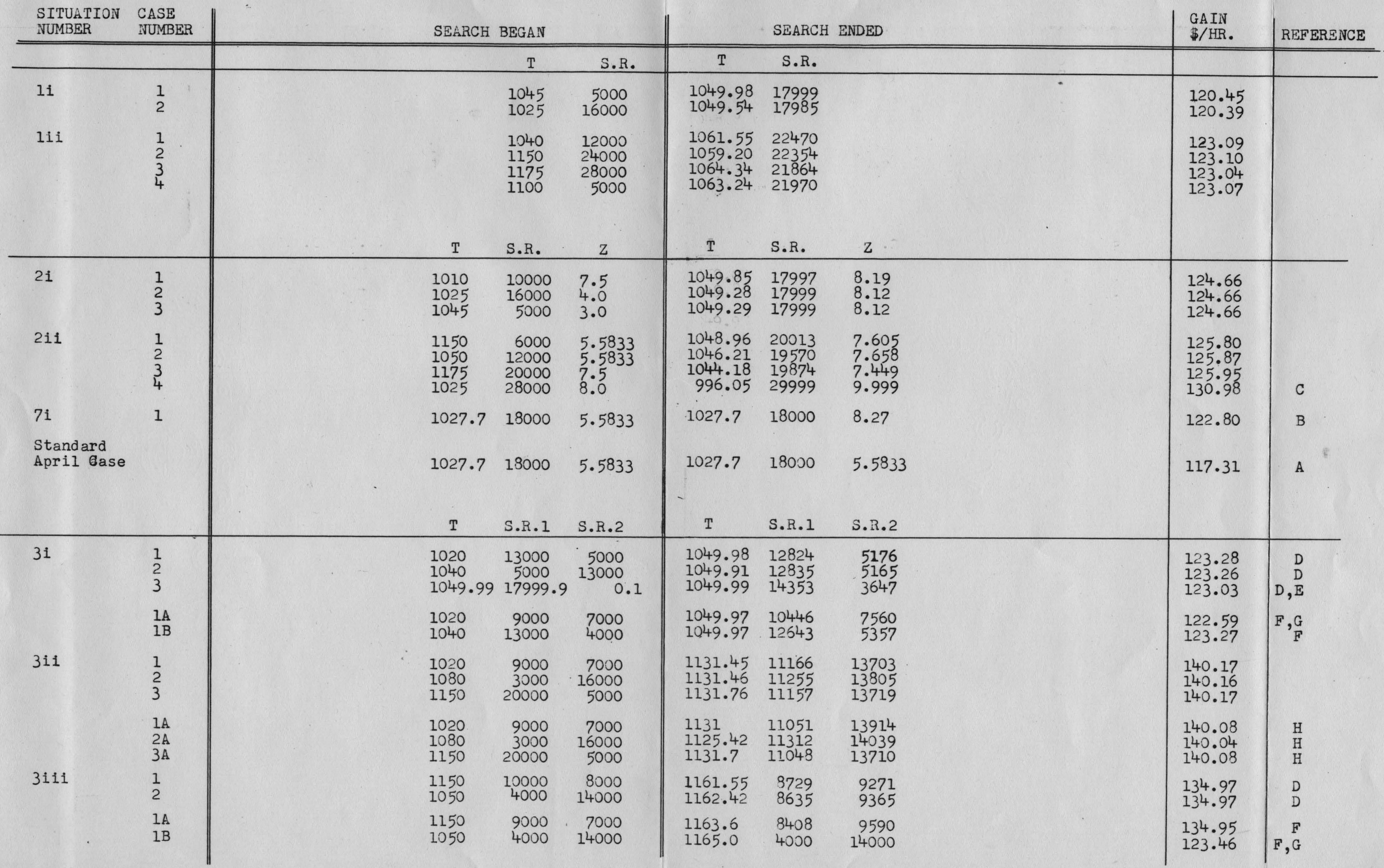




\begin{tabular}{|c|c|c|c|c|c|c|c|c|c|c|c|c|c|c|c|}
\hline & & & $\mathrm{T}$ & S.R.I & S.R.2 & 21 & $\mathrm{z} 2$ & $\mathrm{~T}$ & S.R.I & S.R.2 & $\mathrm{Zl}$ & $\mathrm{Z2}$ & & & \\
\hline \multirow[t]{2}{*}{$4 i$} & $\frac{1}{2}$ & & $\begin{array}{l}1040 \\
1025\end{array}$ & $\begin{array}{r}12000 \\
6000\end{array}$ & $\begin{array}{r}6000 \\
12000\end{array}$ & $\begin{array}{l}3 \\
3\end{array}$ & $\begin{array}{l}6 \\
6\end{array}$ & $\begin{array}{l}1049.96 \\
1049.56\end{array}$ & $\begin{array}{l}9900 \\
9543\end{array}$ & $\begin{array}{l}8100 \\
8457\end{array}$ & $\begin{array}{l}1.892 \\
2.268\end{array}$ & $\begin{array}{l}6.180 \\
7.367\end{array}$ & & $\begin{array}{l}133.44 \\
132.95\end{array}$ & $\begin{array}{r}D \\
D, G\end{array}$ \\
\hline & $\frac{1 \mathrm{~A}}{2 \mathrm{~A}}$ & & $\begin{array}{l}1040 \\
1010\end{array}$ & $\begin{array}{r}9000 \\
13000\end{array}$ & $\begin{array}{l}7000 \\
4000\end{array}$ & $\begin{array}{l}3 \\
6\end{array}$ & $\begin{array}{l}3 \\
6\end{array}$ & $\begin{array}{l}1049.93 \\
1048.8\end{array}$ & $\begin{array}{l}10322 \\
13312\end{array}$ & $\begin{array}{l}7678 \\
4704\end{array}$ & $\begin{array}{l}1.814 \\
5.394\end{array}$ & $\begin{array}{l}6.551 \\
5,169\end{array}$ & & $\begin{array}{l}133.30 \\
123.70\end{array}$ & $\begin{array}{r}F \\
F, G\end{array}$ \\
\hline \multirow[t]{2}{*}{$4 i i$} & $\begin{array}{l}1 \\
2 \\
3\end{array}$ & & $\begin{array}{l}1150 \\
1050 \\
1150\end{array}$ & $\begin{array}{l}9000 \\
5000 \\
9000\end{array}$ & $\begin{array}{r}7000 \\
13000 \\
7000\end{array}$ & $\begin{array}{l}2.7916 \\
4 \\
2.7916\end{array}$ & $\begin{array}{l}2.7916 \\
2 \\
2.7916\end{array}$ & $\begin{array}{l}1054.66 \\
1052.5 \\
1051.57\end{array}$ & $\begin{array}{l}12809 \\
10530 \\
11463\end{array}$ & $\begin{array}{l}17752 \\
19470 \\
18315\end{array}$ & $\begin{array}{l}2.717 \\
2.627 \\
2.798\end{array}$ & $\begin{array}{l}9.92 \\
9.99 \\
9.92\end{array}$ & & $\begin{array}{l}159.91 \\
161.11 \\
160.80\end{array}$ & \\
\hline & & $\mathrm{T}$ & S.R.1 & S.R.2 & $\mathrm{Zl}$ & $\mathrm{z} 2$ & $P$ & $\mathrm{~T}$ & S.R.I & S.R.2 & $\mathrm{ZI}$ & $\mathrm{Z} 2$ & $P$ & & \\
\hline \multirow[t]{2}{*}{$5 i$} & $\frac{1}{2}$ & $\begin{array}{l}1020 \\
1040\end{array}$ & $\begin{array}{r}8000 \\
14000\end{array}$ & $\begin{array}{r}10000 \\
4000\end{array}$ & $\begin{array}{l}6 \\
3\end{array}$ & $\begin{array}{l}2 \\
5\end{array}$ & $\begin{array}{l}2.4 \\
2.1\end{array}$ & $\begin{array}{l}1050.00 \\
1049.88\end{array}$ & $\begin{array}{l}10209 \\
11389\end{array}$ & $\begin{array}{l}7791 \\
6611\end{array}$ & $\begin{array}{l}2.236 \\
2.845\end{array}$ & $\begin{array}{l}9.724 \\
9.57\end{array}$ & $\begin{array}{l}2.00 \\
2.00\end{array}$ & $\begin{array}{l}143.98 \\
143.06\end{array}$ & $\begin{array}{l}D \\
D\end{array}$ \\
\hline & $\frac{1 \mathrm{~A}}{2 \mathrm{~A}}$ & $\begin{array}{l}1040 \\
1025\end{array}$ & $\begin{array}{r}10000 \\
7000\end{array}$ & $\begin{array}{l}4000 \\
5000\end{array}$ & $\begin{array}{l}4 \\
4\end{array}$ & $\begin{array}{l}4 \\
3\end{array}$ & $\begin{array}{l}2.25 \\
2.40\end{array}$ & $\begin{array}{l}1049.97 \\
1049.56\end{array}$ & $\begin{array}{l}13850 \\
11589\end{array}$ & $\begin{array}{l}4152 \\
6270\end{array}$ & $\begin{array}{l}3.798 \\
1.894\end{array}$ & $\begin{array}{l}8.289 \\
7.699\end{array}$ & $\begin{array}{l}2.00 \\
2.01\end{array}$ & $\begin{array}{l}140.04 \\
140.49\end{array}$ & $\underset{F}{G}$ \\
\hline \multirow[t]{2}{*}{$5 i 1$} & $\frac{1}{2}$ & $\begin{array}{l}1150 \\
1100\end{array}$ & $\begin{array}{l}9000 \\
5000\end{array}$ & $\begin{array}{r}7000 \\
13000\end{array}$ & $\frac{2}{6} \cdot 7916$ & $\frac{2.7916}{2}$ & $\begin{array}{l}2.25 \\
2.10\end{array}$ & $\begin{array}{l}1081 \\
1076.48\end{array}$ & $\begin{array}{l}11370 \\
11897\end{array}$ & $\begin{array}{l}17810 \\
18105\end{array}$ & $\begin{array}{l}3.73 \\
4.06\end{array}$ & $\begin{array}{r}9.99 \\
10.00\end{array}$ & $\begin{array}{l}2.01 \\
2.00\end{array}$ & $\begin{array}{l}169.85 \\
170.49\end{array}$ & $\begin{array}{l}\text { C } \\
\text { C }\end{array}$ \\
\hline & & & $\mathrm{T}$ & S.R.I & S.R.2 & 21 & $\mathrm{Z} 2$ & $\mathrm{~T}$ & S.R.I & S.R.2 & $\mathrm{ZI}$ & $\mathrm{z} 2$ & & & \\
\hline 61 & 1 & & 1025 & 10000 & 4000 & 1.5 & 1.5 & 1050 & 11214 & 6778 & 2.341 & 3.242 & & 124.99 & \\
\hline $6 i i$ & $\frac{1}{2}$ & & $\begin{array}{l}1020 \\
1025\end{array}$ & $\begin{array}{l}14000 \\
11000\end{array}$ & $\begin{array}{l}3000 \\
6600\end{array}$ & $\begin{array}{l}2 \\
2.34\end{array}$ & $\begin{array}{l}2 \\
3.24\end{array}$ & $\begin{array}{l}1027.67 \\
1027.64\end{array}$ & $\begin{array}{l}14538 \\
11292\end{array}$ & $\begin{array}{l}3456 \\
6703\end{array}$ & $\begin{array}{l}3.168 \\
2.324\end{array}$ & $\begin{array}{l}2.414 \\
3.259\end{array}$ & & $\begin{array}{l}117.89 \\
119.87\end{array}$ & G \\
\hline 6iii & $\frac{1}{2}$ & & $\begin{array}{l}1025 \\
1100\end{array}$ & $\begin{array}{r}11000 \\
5000\end{array}$ & $\begin{array}{l}6600 \\
5000\end{array}$ & $\begin{array}{l}2.34 \\
1.75\end{array}$ & $\begin{array}{l}3.24 \\
3.00\end{array}$ & $\begin{array}{l}1153.48 \\
1155.44\end{array}$ & $\begin{array}{l}8955 \\
8167\end{array}$ & $\begin{array}{l}8890 \\
9831\end{array}$ & $\begin{array}{l}1.739 \\
1.796\end{array}$ & $\begin{array}{l}3.848 \\
3.792\end{array}$ & & $\begin{array}{l}139.44 \\
140.19\end{array}$ & \\
\hline $6 \mathrm{iv}$ & $\frac{1}{2}$ & & $\begin{array}{l}1020 \\
1045\end{array}$ & $\begin{array}{r}14000 \\
8000\end{array}$ & $\begin{array}{l}3000 \\
8000\end{array}$ & $\begin{array}{l}2 \\
1.75\end{array}$ & $\begin{array}{l}2 \\
3\end{array}$ & $\begin{array}{l}1049.83 \\
1049.96\end{array}$ & $\begin{array}{l}16002 \\
11998\end{array}$ & $\begin{array}{l}11437 \\
15082\end{array}$ & $\begin{array}{l}3.133 \\
2.115\end{array}$ & $\begin{array}{l}2.452 \\
3.469\end{array}$ & & $\begin{array}{l}129.03 \\
133.40\end{array}$ & G \\
\hline $6 v$ & $\frac{1}{2}$ & & $\begin{array}{l}1137 \\
1060\end{array}$ & $\begin{array}{r}11000 \\
5000\end{array}$ & $\begin{array}{r}6000 \\
20000\end{array}$ & $\frac{1.60}{2}$ & $\frac{3.80}{2}$ & $\begin{array}{l}1124.72 \\
1130.76\end{array}$ & $\begin{array}{l}9038 \\
9757\end{array}$ & $\begin{array}{l}15528 \\
14368\end{array}$ & $\begin{array}{l}1.740 \\
2.04\end{array}$ & $\begin{array}{l}3.841 \\
3.544\end{array}$ & & $\begin{array}{l}144.53 \\
144.14\end{array}$ & \\
\hline $6 v i$ & $\begin{array}{l}1 \\
2 \\
3\end{array}$ & & $\begin{array}{l}1025 \\
1025 \\
1025\end{array}$ & $\begin{array}{r}11000 \\
10000 \\
8000\end{array}$ & $\begin{array}{r}6600 \\
10000 \\
12000\end{array}$ & $\begin{array}{l}2.34 \\
1.75 \\
2\end{array}$ & $\begin{array}{l}3.24 \\
2.00 \\
3\end{array}$ & $\begin{array}{l}1027.7 \\
1027.7 \\
1027.65\end{array}$ & $\begin{array}{l}13769 \\
16530 \\
12797\end{array}$ & $\begin{array}{r}13218 \\
9500 \\
13934\end{array}$ & $\begin{array}{l}2.331 \\
2.971 \\
2.032\end{array}$ & $\begin{array}{l}3.252 \\
2.613 \\
3.553\end{array}$ & $\therefore$ & $\begin{array}{l}126.39 \\
124.19 \\
127.25\end{array}$ & G \\
\hline
\end{tabular}


APPENDIX 13

SELECTED CASES - COMPLETE_OPTIMUM OPERATING CONDITIONS

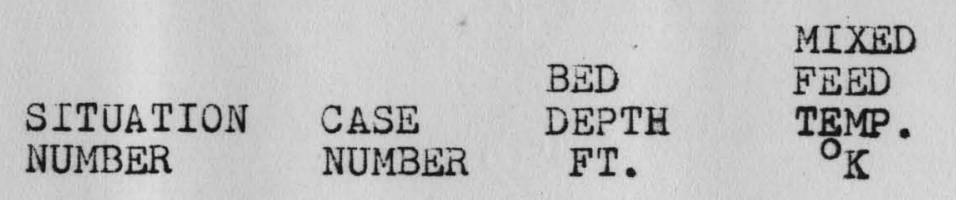

PRESSURE

ATMOS.
$\mathrm{X} 1$. $\mathrm{x} 2$ $\mathrm{x} 3$
$\mathrm{XI} 4$ $\mathrm{x} 15$
$\mathrm{X} 16$
Conditions at Entrance to Bed 1 Conditions at Exit of Bed 1 Conditions at Entrance to Bed Conditions at Exit of Bed 2
For Single Bed Cases This is Naturally Missing

LB./HR. INDICATED PRODUCTS

ETHYLBENZENE

TYRENE HYDROGEN ETHYLENE TOLUENE ETHANE ACETYLENE $\mathrm{C}_{6} \mathrm{H}_{5} \mathrm{C}_{2} \mathrm{H}$ STEAM

\begin{tabular}{|c|c|c|c|c|c|c|c|c|c|c|c|c|}
\hline & & & & & & ETHANE & ACETYLENE & $\mathrm{C}_{6} \mathrm{H}_{5} \mathrm{C}_{2} \mathrm{H}$ & STEAM & Co & $\mathrm{CO}_{2}$ & CARBON \\
\hline \multirow[t]{2}{*}{11} & $\frac{1}{*}$ & & $\begin{array}{c}0 \\
5.5833\end{array}$ & $\begin{array}{l}934.76 \\
857.27\end{array}$ & $\begin{array}{l}2.37 \\
2.29\end{array}$ & $\begin{array}{c}0.0 \\
.42537 \mathrm{E} 00 \\
4229.12 \\
0.0\end{array}$ & $\begin{array}{c}0.0 \\
.47539 \mathrm{E}-01 \\
3754.86 \\
0.0\end{array}$ & $\begin{array}{c}0.0 \\
.37083 \mathrm{E}-01 \\
108.62 \\
0.0\end{array}$ & $\begin{array}{c}0.0 \\
.58996 \mathrm{E}-02 \\
25.75 \\
17748.65\end{array}$ & $\begin{array}{c}0.0 \\
.11492 \mathrm{E}-02 \\
320.42 \\
1.99\end{array}$ & $\begin{array}{l}0.0 \\
.69774 \text { E-02 } \\
454.98 \\
304.65\end{array}$ & $\begin{array}{c}29.82 \\
0.0\end{array}$ \\
\hline & * & Began & Search at & 1049.98 & 17983 & & & $\$ / \mathrm{Hr}$ & $\$ 120.43$ & & & \\
\hline lii & 4 & & $\stackrel{0}{5.5833}$ & $\begin{array}{l}956.09 \\
877.65\end{array}$ & $\begin{array}{l}2.638 \\
2.545\end{array}$ & $\begin{array}{c}0.0 \\
.46560 \\
3608.98 \\
0\end{array}$ & $\begin{array}{c}0 \\
.69078 \mathrm{E}-01 \\
4095.46 \\
0\end{array}$ & $\begin{array}{c}0 \\
.47167 \text { E-01 } \\
138.14 \\
0\end{array}$ & $\begin{array}{c}0 \\
.76669 \mathrm{E}-02 \\
26.28^{\mathrm{E}} \\
21577.19\end{array}$ & $\begin{array}{c}0 \\
.13050 \mathrm{E}-02 \\
457.20 \\
2.16\end{array}$ & $\begin{array}{l}0 \\
.89089 \text { E-02 } \\
532.03 \\
478.56\end{array}$ & $\begin{array}{c}35.96 \\
0.0\end{array}$ \\
\hline $2 i$ & 3 & - & $\begin{array}{l}0 \\
8.128\end{array}$ & $\begin{array}{l}934.79 \\
851.67\end{array}$ & $\begin{array}{l}2.37 \\
2.25\end{array}$ & $\begin{array}{c}0 \\
.45054 \mathrm{E} 00 \\
3890.27 \\
0.0\end{array}$ & $\begin{array}{c}0 \\
.47896 \text { E-01 } \\
3967.98 \\
0.0\end{array}$ & $\begin{array}{c}0 \\
.50813 \text { E-01 } \\
121.29 \\
0.0\end{array}$ & $\begin{array}{c}0 \\
.66211 \mathrm{E}-02 \\
16.40 \\
17687.05\end{array}$ & $\begin{array}{c}0 \\
.19400 \mathrm{E}-02 \\
322.70 \\
1.86\end{array}$ & $\begin{array}{c}0 \\
.84948 \text { E-02 } \\
559.33 \\
373.73\end{array}$ & $\begin{array}{c}35.16 \\
0.0\end{array}$ \\
\hline $2 i i$ & 3 & & $\begin{array}{c}0 \\
7.450\end{array}$ & $\begin{array}{l}938.22 \\
839.00\end{array}$ & $\begin{array}{l}2.50 \\
2.38\end{array}$ & $\begin{array}{c}0 \\
.45711 \text { E } 00 \\
3832.10 \\
0.0\end{array}$ & $\begin{array}{c}0 \\
50198 \text { E-01 } \\
4023.55 \\
0.0\end{array}$ & $\begin{array}{c}0 \\
.48688 \mathrm{E}-01 \\
123.87 \\
0.0\end{array}$ & $\begin{array}{c}0 \\
.63371 \text { E-02 } \\
16.34 \\
19559.00\end{array}$ & $\begin{array}{c}0 \\
.16279 \mathrm{E}-02 \\
337.31 \\
1.78\end{array}$ & $\begin{array}{c}0 \\
.79074 \text { E-02 } \\
543.42 \\
384.25\end{array}$ & $\begin{array}{c}34.66 \\
0.0\end{array}$ \\
\hline $7 i$ & 1 & & $\begin{array}{c}0 \\
8.27\end{array}$ & $\begin{array}{l}922.59 \\
843.64\end{array}$ & $\begin{array}{l}2.37 \\
2.25\end{array}$ & $\begin{array}{c}0.0 \\
.43416 \mathrm{E} 00 \\
4145.09 \\
0.0\end{array}$ & $\begin{array}{c}0 \\
.41189 \mathrm{E}-01 \\
3829.28 \\
0.0\end{array}$ & $\begin{array}{c}0 \\
.44378 \mathrm{E}-01 \\
111.35 \\
0.0\end{array}$ & $\begin{array}{c}0 \\
.56726 \mathrm{E}-02 \\
14.37 \\
17738.56\end{array}$ & $\begin{array}{c}0 \\
.16189 \mathrm{E}-02 \\
280.11 \\
1.63\end{array}$ & $\begin{array}{c}0 \\
.72332 \text { E-02 } \\
511.13 \\
318.33\end{array}$ & $\begin{array}{c}30.90 \\
0.0\end{array}$ \\
\hline $3 i$ & 1 & & $\begin{array}{c}0 \\
2.79165 \\
0 \\
2.79165\end{array}$ & $\begin{array}{l}911.17 \\
346.79 \\
881.95 \\
860.17\end{array}$ & $\begin{array}{l}2 \cdot 37 \\
2 \cdot 34 \\
2 \cdot 34 \\
2 \cdot 30\end{array}$ & $\begin{array}{c}0 \\
.3096 \text { E } 00 \\
.3096 \text { E } 00 \\
.4245 \text { E } 00 \\
4347.93 \\
0.0\end{array}$ & $\begin{array}{c}0 \\
.2426 \mathrm{E}-01 \\
.2426 \mathrm{E}-01 \\
.3360 \mathrm{E}-01 \\
3747.66 \\
0.0\end{array}$ & $\begin{array}{c}0 \\
.2081 \mathrm{E}-01 \\
.2081 \mathrm{E}-01 \\
.3810 \mathrm{E}-01 \\
98.19 \\
0.0\end{array}$ & $\begin{array}{c}0 \\
.3153 \mathrm{E}-02 \\
.2246 \mathrm{E}-02 \\
.4088 \mathrm{E}-02 \\
19.30 \\
17809.07\end{array}$ & $\begin{array}{c}0 \\
.5921 \mathrm{E}-03 \\
.4219 \mathrm{E}-03 \\
.1249 \mathrm{E}-02 \\
231.93 \\
1.86\end{array}$ & $\begin{array}{c}0 \\
.3675 \mathrm{E}-02 \\
.2618 \mathrm{E}-02 \\
.5270 \mathrm{E}-02 \\
464.13 \\
231.95\end{array}$ & $\begin{array}{c}29.65 \\
0.0\end{array}$ \\
\hline
\end{tabular}

\begin{tabular}{|c|c|c|c|c|c|c|c|c|c|c|c|c|}
\hline & & & & & & ETHANE & ACETYLENE & $\mathrm{C}_{6} \mathrm{H}_{5} \mathrm{C}_{2} \mathrm{H}$ & STEAM & Co & $\mathrm{CO}_{2}$ & CARBON \\
\hline \multirow[t]{2}{*}{11} & $\frac{1}{*}$ & & $\begin{array}{c}0 \\
5.5833\end{array}$ & $\begin{array}{l}934.76 \\
857.27\end{array}$ & $\begin{array}{l}2.37 \\
2.29\end{array}$ & $\begin{array}{c}0.0 \\
.42537 \mathrm{E} 00 \\
4229.12 \\
0.0\end{array}$ & $\begin{array}{c}0.0 \\
.47539 \mathrm{E}-01 \\
3754.86 \\
0.0\end{array}$ & $\begin{array}{c}0.0 \\
.37083 \mathrm{E}-01 \\
108.62 \\
0.0\end{array}$ & $\begin{array}{c}0.0 \\
.58996 \mathrm{E}-02 \\
25.75 \\
17748.65\end{array}$ & $\begin{array}{c}0.0 \\
.11492 \mathrm{E}-02 \\
320.42 \\
1.99\end{array}$ & $\begin{array}{l}0.0 \\
.69774 \text { E-02 } \\
454.98 \\
304.65\end{array}$ & $\begin{array}{c}29.82 \\
0.0\end{array}$ \\
\hline & * & Began & Search at & 1049.98 & 17983 & & & $\$ / \mathrm{Hr}$ & $\$ 120.43$ & & & \\
\hline lii & 4 & & $\stackrel{0}{5.5833}$ & $\begin{array}{l}956.09 \\
877.65\end{array}$ & $\begin{array}{l}2.638 \\
2.545\end{array}$ & $\begin{array}{c}0.0 \\
.46560 \\
3608.98 \\
0\end{array}$ & $\begin{array}{c}0 \\
.69078 \mathrm{E}-01 \\
4095.46 \\
0\end{array}$ & $\begin{array}{c}0 \\
.47167 \text { E-01 } \\
138.14 \\
0\end{array}$ & $\begin{array}{c}0 \\
.76669 \mathrm{E}-02 \\
26.28^{\mathrm{E}} \\
21577.19\end{array}$ & $\begin{array}{c}0 \\
.13050 \mathrm{E}-02 \\
457.20 \\
2.16\end{array}$ & $\begin{array}{l}0 \\
.89089 \text { E-02 } \\
532.03 \\
478.56\end{array}$ & $\begin{array}{c}35.96 \\
0.0\end{array}$ \\
\hline $2 i$ & 3 & - & $\begin{array}{l}0 \\
8.128\end{array}$ & $\begin{array}{l}934.79 \\
851.67\end{array}$ & $\begin{array}{l}2.37 \\
2.25\end{array}$ & $\begin{array}{c}0 \\
.45054 \mathrm{E} 00 \\
3890.27 \\
0.0\end{array}$ & $\begin{array}{c}0 \\
.47896 \text { E-01 } \\
3967.98 \\
0.0\end{array}$ & $\begin{array}{c}0 \\
.50813 \text { E-01 } \\
121.29 \\
0.0\end{array}$ & $\begin{array}{c}0 \\
.66211 \mathrm{E}-02 \\
16.40 \\
17687.05\end{array}$ & $\begin{array}{c}0 \\
.19400 \mathrm{E}-02 \\
322.70 \\
1.86\end{array}$ & $\begin{array}{c}0 \\
.84948 \text { E-02 } \\
559.33 \\
373.73\end{array}$ & $\begin{array}{c}35.16 \\
0.0\end{array}$ \\
\hline $2 i i$ & 3 & & $\begin{array}{c}0 \\
7.450\end{array}$ & $\begin{array}{l}938.22 \\
839.00\end{array}$ & $\begin{array}{l}2.50 \\
2.38\end{array}$ & $\begin{array}{c}0 \\
.45711 \text { E } 00 \\
3832.10 \\
0.0\end{array}$ & $\begin{array}{c}0 \\
50198 \text { E-01 } \\
4023.55 \\
0.0\end{array}$ & $\begin{array}{c}0 \\
.48688 \mathrm{E}-01 \\
123.87 \\
0.0\end{array}$ & $\begin{array}{c}0 \\
.63371 \text { E-02 } \\
16.34 \\
19559.00\end{array}$ & $\begin{array}{c}0 \\
.16279 \mathrm{E}-02 \\
337.31 \\
1.78\end{array}$ & $\begin{array}{c}0 \\
.79074 \text { E-02 } \\
543.42 \\
384.25\end{array}$ & $\begin{array}{c}34.66 \\
0.0\end{array}$ \\
\hline $7 i$ & 1 & & $\begin{array}{c}0 \\
8.27\end{array}$ & $\begin{array}{l}922.59 \\
843.64\end{array}$ & $\begin{array}{l}2.37 \\
2.25\end{array}$ & $\begin{array}{c}0.0 \\
.43416 \mathrm{E} 00 \\
4145.09 \\
0.0\end{array}$ & $\begin{array}{c}0 \\
.41189 \mathrm{E}-01 \\
3829.28 \\
0.0\end{array}$ & $\begin{array}{c}0 \\
.44378 \mathrm{E}-01 \\
111.35 \\
0.0\end{array}$ & $\begin{array}{c}0 \\
.56726 \mathrm{E}-02 \\
14.37 \\
17738.56\end{array}$ & $\begin{array}{c}0 \\
.16189 \mathrm{E}-02 \\
280.11 \\
1.63\end{array}$ & $\begin{array}{c}0 \\
.72332 \text { E-02 } \\
511.13 \\
318.33\end{array}$ & $\begin{array}{c}30.90 \\
0.0\end{array}$ \\
\hline $3 i$ & 1 & & $\begin{array}{c}0 \\
2.79165 \\
0 \\
2.79165\end{array}$ & $\begin{array}{l}911.17 \\
346.79 \\
881.95 \\
860.17\end{array}$ & $\begin{array}{l}2 \cdot 37 \\
2 \cdot 34 \\
2 \cdot 34 \\
2 \cdot 30\end{array}$ & $\begin{array}{c}0 \\
.3096 \text { E } 00 \\
.3096 \text { E } 00 \\
.4245 \text { E } 00 \\
4347.93 \\
0.0\end{array}$ & $\begin{array}{c}0 \\
.2426 \mathrm{E}-01 \\
.2426 \mathrm{E}-01 \\
.3360 \mathrm{E}-01 \\
3747.66 \\
0.0\end{array}$ & $\begin{array}{c}0 \\
.2081 \mathrm{E}-01 \\
.2081 \mathrm{E}-01 \\
.3810 \mathrm{E}-01 \\
98.19 \\
0.0\end{array}$ & $\begin{array}{c}0 \\
.3153 \mathrm{E}-02 \\
.2246 \mathrm{E}-02 \\
.4088 \mathrm{E}-02 \\
19.30 \\
17809.07\end{array}$ & $\begin{array}{c}0 \\
.5921 \mathrm{E}-03 \\
.4219 \mathrm{E}-03 \\
.1249 \mathrm{E}-02 \\
231.93 \\
1.86\end{array}$ & $\begin{array}{c}0 \\
.3675 \mathrm{E}-02 \\
.2618 \mathrm{E}-02 \\
.5270 \mathrm{E}-02 \\
464.13 \\
231.95\end{array}$ & $\begin{array}{c}29.65 \\
0.0\end{array}$ \\
\hline
\end{tabular}




\begin{tabular}{|c|c|c|c|c|c|c|c|c|c|c|c|}
\hline $3 i$ & $1 B$ & $\begin{array}{c}0 \\
2.79165 \\
0 \\
2.79165\end{array}$ & $\begin{array}{l}910.16 \\
845.66 \\
882.25 \\
860.28\end{array}$ & $\begin{array}{l}2.37 \\
2 \cdot 34 \\
2.34 \\
2.30\end{array}$ & $\begin{array}{c}0 \\
.3082 \text { E } 00 \\
.3032 \text { E OO } \\
.4243 \text { E } 00 \\
4353.04 \\
0.0\end{array}$ & $\begin{array}{c}0 \\
.2373 \mathrm{E}-01 \\
.2373 \mathrm{E}-01 \\
.3317 \mathrm{E}-01 \\
3745.67 \\
0.0\end{array}$ & $\begin{array}{c}0 \\
.2089 \mathrm{E}-01 \\
.2089 \mathrm{E}-01 \\
.3818 \mathrm{E}-01 \\
97.83 \\
0.0\end{array}$ & $\begin{array}{c}0 \\
.3123 \mathrm{E}-02 \\
.2195 \mathrm{E}-02 \\
.4031 \mathrm{E}-02 \\
19.10 \\
17810.60\end{array}$ & $\begin{array}{c}0 \\
.6035 \mathrm{E}-03 \\
.4239 \mathrm{E}-03 \\
.1254 \mathrm{E}-02 \\
229.14 \\
1.86\end{array}$ & $\begin{array}{c}0 \\
.3657 \\
.2568 \mathrm{E}-02 \\
.5219 \mathrm{E}-02 \\
.02 \\
464.74 \\
229.67\end{array}$ & $\begin{array}{c}29.67 \\
0.0\end{array}$ \\
\hline $3 i 1$ & 1 & $\begin{array}{c}0 \\
2.79165 \\
0 \\
2.79165\end{array}$ & $\begin{array}{l}934.74 \\
854.54 \\
958.89 \\
923.90\end{array}$ & $\begin{array}{l}2.37 \\
2.34 \\
2.34 \\
2.29\end{array}$ & $\begin{array}{c}0 \\
.3502 \text { E OO } \\
.3502 \text { E OO } \\
.5413 \text { E OO } \\
2735.59 \\
0.0 \\
0\end{array}$ & $\begin{array}{c}0 \\
.3638 \mathrm{E}-01 \\
.3638 \mathrm{E}-01 \\
.8094 \mathrm{E}-01 \\
.836 .48 \\
0.0 \\
0\end{array}$ & $\begin{array}{c}0 \\
.3468 \mathrm{E}-01 \\
.3468 \mathrm{E}-01 \\
.6078 \mathrm{E}-01 \\
160.63 \\
0.0\end{array}$ & $\begin{array}{c}0 \\
.5433 \text { E-02 } \\
.2439 \mathrm{E}-02 \\
.7354 \text { E-02 } \\
42.08 \\
24414.91 \\
\end{array}$ & $\begin{array}{c}0 \\
.1371 \mathrm{E}-02 \\
.6157 \mathrm{E}-03 \\
.1833 \mathrm{E}-02 \\
532.55 \\
4.41\end{array}$ & $\begin{array}{cc}0 \\
.6692 & \mathrm{E}-02 \\
.3005 & \mathrm{E}-02 \\
.9073 \mathrm{E}-02 \\
634.02 \\
551.70 \\
\end{array}$ & $\begin{array}{c}38.64 \\
0.0\end{array}$ \\
\hline $3 i i$ & $1 \mathrm{~A}$ & $\begin{array}{c}0 \\
2.79165 \\
0 \\
2.79165\end{array}$ & $\begin{array}{l}933.58 \\
852.20 \\
958.62 \\
923.98\end{array}$ & $\begin{array}{l}2.37 \\
2.34 \\
2.34 \\
2.28\end{array}$ & $\begin{array}{c}0.0 \\
.3522 \mathrm{E} 00 \\
.3522 \mathrm{E} 00 \\
.5416 \mathrm{E} 00 \\
2729.79 \\
0.0\end{array}$ & $\begin{array}{c}0.0 \\
.3699 \mathrm{E}-01 \\
.3699 \mathrm{E}-01 \\
.8112 \mathrm{E}-01 \\
4738.87 \\
0.0\end{array}$ & $\begin{array}{c}0 \\
.3507 \mathrm{E}-01 \\
.3507 \mathrm{E}-01 \\
.6100 \mathrm{E}-01 \\
161.01 \\
0.0\end{array}$ & $\begin{array}{c}0 \\
.5583 \mathrm{E}-02 \\
.2471 \mathrm{E}-02 \\
.7355 \mathrm{E}-02 \\
41.92 \\
24509.74 \\
\end{array}$ & $\begin{array}{cc}0 \\
.1411 \\
.6245 & \mathrm{E}-02 \\
.624 \\
.1837 \mathrm{E}-02 \\
533.64 \\
4.41 \\
4\end{array}$ & $\begin{array}{cc}0 \\
.6884 & \mathrm{E}-02 \\
.3047 & \mathrm{E}-02 \\
.9078 & \mathrm{E}-02 \\
635.66 \\
554.12\end{array}$ & $\begin{array}{c}38.69 \\
0.0\end{array}$ \\
\hline $3 i i i$ & 2 & $\begin{array}{c}0 \\
2.79165 \\
0 \\
2.79165\end{array}$ & $\begin{array}{l}921.24 \\
837.59 \\
940.88 \\
900.39\end{array}$ & $\begin{array}{l}2 \cdot 37 \\
2 \cdot 35 \\
2 \cdot 35 \\
2.30\end{array}$ & $\begin{array}{c}0.0 \\
.3281 \mathrm{E} 00 \\
.3281 \mathrm{E} 00 \\
.5136 \mathrm{E} 00 \\
3018.39 \\
0.0\end{array}$ & $\begin{array}{c}0.0 \\
.2853 \mathrm{E}-01 \\
.2853 \mathrm{E}-01 \\
.6273 \mathrm{E}-01 \\
4501.59 \\
0.0\end{array}$ & $\begin{array}{c}0.0 \\
.3997 \mathrm{E}-01 \\
.3997 \mathrm{E}-01 \\
.73979 \mathrm{E}-01 \\
143.74 \\
0.0\end{array}$ & $\begin{array}{c}0.0 \\
.5308 \mathrm{E}-02 \\
.2546 \mathrm{E}-02 \\
.7622 \mathrm{E}-02 \\
36.14 \\
17613.73 \\
\end{array}$ & $\begin{array}{c}0.0 \\
.2148 \mathrm{E}-02 \\
.1030 \mathrm{E}-02 \\
.3167 \mathrm{E}-02 \\
416.87 \\
3.43\end{array}$ & $\begin{array}{c}0.0 \\
.7334 \mathrm{E}-02 \\
.3518 \mathrm{E}-02 \\
.1067 \mathrm{E}-01 \\
732.85 \\
469.51\end{array}$ & $\begin{array}{c}45.64 \\
0.0 \\
\end{array}$ \\
\hline $4 i$ & 1 & $\begin{array}{c}0 \\
1.892 \\
0 \\
6.180\end{array}$ & $\begin{array}{l}892.97 \\
837.41 \\
894.73 \\
851.87\end{array}$ & $\begin{array}{l}2.37 \\
2.35 \\
2.35 \\
2.26\end{array}$ & $\begin{array}{ccc}0 & & \\
.2409 & \mathrm{E} & 00 \\
.4642 & \mathrm{E} & 00 \\
.4642 & \mathrm{E} & 00 \\
3893.35 & \\
0.0 & \end{array}$ & $\begin{array}{c}0 \\
.1416 \mathrm{E}-01 \\
.1416 \mathrm{E}-01 \\
.3421 \mathrm{E}-01 \\
4083.69 \\
0.0\end{array}$ & $\begin{array}{c}0 \\
.1431 \mathrm{E}-01 \\
.1431 \mathrm{E}-01 \\
.5047 \mathrm{E}-01 \\
112.39 \\
0.0\end{array}$ & $\begin{array}{c}0 \\
.1959 \mathrm{E}-02 \\
.1078 \mathrm{E}-02 \\
.4658 \mathrm{E}-02 \\
12.69 \\
17760.60\end{array}$ & $\begin{array}{c}0 \\
.4059 \mathrm{E}-03 \\
.2232 \mathrm{E}-03 \\
.2022 \mathrm{E}-02 \\
235.80 \\
1.70 \\
\end{array}$ & $\begin{array}{cc}0 \\
.2301 \\
.1266 & \mathrm{E}-02 \\
.02 \\
.6620 \mathrm{E}-02 \\
556.79 \\
291.34\end{array}$ & $\begin{array}{c}33.39 \\
0.0\end{array}$ \\
\hline $4 i$ & $1 \mathrm{~A}$ & $\begin{array}{l}0 \\
1.814 \\
0 \\
6.551\end{array}$ & $\begin{array}{l}895.87 \\
841.70 \\
894.93 \\
851.15\end{array}$ & $\begin{array}{l}2.37 \\
2.35 \\
2.35 \\
2.25\end{array}$ & $\begin{array}{c}0.0 \\
.2390 \mathrm{E} 00 \\
.2390 \mathrm{E} 00 \\
.4659 \mathrm{E} 00 \\
3857.01 \\
0.0\end{array}$ & $\begin{array}{c}0 \\
.1488 \mathrm{E}-01 \\
.1488 \mathrm{E}-01 \\
.3555 \mathrm{E}-01 \\
4098.16 \\
0.0\end{array}$ & $\begin{array}{c}0 \\
.1348 \mathrm{E}-01 \\
.1348 \mathrm{E}-01 \\
.5163 \mathrm{E}-01 \\
114.51 \\
0.0\end{array}$ & $\begin{array}{c}0 \\
.1950 \mathrm{E}-02 \\
.1118 \mathrm{E}-02 \\
.4898 \mathrm{E}-02 \\
12.38 \\
17749.29\end{array}$ & $\begin{array}{c}0 \\
.3542 \mathrm{E}-03 \\
.2031 \mathrm{E}-03 \\
.2091 \mathrm{E}-02 \\
244.32 \\
1.70\end{array}$ & $\begin{array}{c}0 \\
.2241 \text { E-02 } \\
.1285 \mathrm{E}-02 \\
.6931 \mathrm{E}-02 \\
565.48 \\
305.01\end{array}$ & $\begin{array}{c}33.78 \\
0.0\end{array}$ \\
\hline $4 i i$ & 3 & $\begin{array}{c}0 \\
2.799 \\
0 \\
9.925\end{array}$ & $\begin{array}{l}903.90 \\
838.65 \\
932.19 \\
887.32\end{array}$ & $\begin{array}{l}2.37 \\
2.34 \\
2.34 \\
2.10\end{array}$ & $\begin{array}{c}0.0 \\
.2989 \mathrm{E} 00 \\
.2989 \mathrm{E} 00 \\
.5935 \mathrm{E} 00 \\
2414.71 \\
0.0\end{array}$ & $\begin{array}{c}0.0 \\
.2034 \mathrm{E}-01 \\
.2034 \mathrm{E}-01 \\
.6660 \mathrm{E}-01 \\
5178.28 \\
0.0\end{array}$ & $\begin{array}{c}0.0 \\
.2145 \mathrm{E}-01 \\
.2145 \mathrm{E}-01 \\
.6013 \mathrm{E}-01 \\
174.48 \\
0.0\end{array}$ & $\begin{array}{c}0.0 \\
.2921 \mathrm{E}-02 \\
.1124 \mathrm{E}-02 \\
.6204 \mathrm{E}-02 \\
7.938 \\
29298.26\end{array}$ & $\begin{array}{c}0.0 \\
.6894 \mathrm{E}-03 \\
.2654 \mathrm{E}-03 \\
.1860 \mathrm{E}-02 \\
441.44 \\
2.18\end{array}$ & $\begin{array}{c}0.0 \\
.3542 \mathrm{E}-02 \\
.1363 \mathrm{E}-02 \\
.8016 \mathrm{E}-02 \\
629.11 \\
583.61\end{array}$ & $\begin{array}{c}29.07 \\
0.0\end{array}$ \\
\hline
\end{tabular}




\begin{tabular}{|c|c|c|c|c|c|c|c|c|c|c|c|}
\hline $5 i$ & 1 & $\begin{array}{c}0 \\
2.236 \\
0 \\
9.724\end{array}$ & $\begin{array}{l}895.12 \\
839.42 \\
894.06 \\
846.48\end{array}$ & $\begin{array}{l}2.00 \\
1.977 \\
1.977 \\
1.813\end{array}$ & $\begin{array}{c}0 \\
.24460 \text { E } 00 \\
.24460 \text { E } 00 \\
.49183 \text { E } 00 \\
3657.35 \\
0.0\end{array}$ & $\begin{array}{l}0 \\
.14730 \mathrm{E}-01 \\
.14730 \mathrm{E}-01 \\
.36288 \mathrm{E}-01 \\
4317.54 \\
0.0 \\
\end{array}$ & $\begin{array}{c}0 \\
.11792 \mathrm{E}-01 \\
.11792 \mathrm{E}-01 \\
.48122 \mathrm{E}-01 \\
120.27 \\
0.0\end{array}$ & $\begin{array}{c}0 \\
.18489 \mathrm{E}-02 \\
.10486 \mathrm{E}-02 \\
.50248 \mathrm{E}-02 \\
12.28 \\
17744.30\end{array}$ & $\begin{array}{c}0 \\
.32166 \mathrm{E}-03 \\
.18243 \mathrm{E}-03 \\
.21177 \mathrm{E}-02 \\
248.98 \\
2.23 \\
\end{array}$ & $\begin{array}{l}0 \\
.20891 \mathrm{E}-02 \\
.11849 \mathrm{E}-02 \\
.70628 \mathrm{E}-02 \\
539.18 \\
310.83\end{array}$ & 28.79 \\
\hline $5 i i$ & 2 & $\begin{array}{c}0 \\
4.062 \\
0 \\
9.999\end{array}$ & $\begin{array}{l}917.10 \\
840.89 \\
943.13 \\
900.41\end{array}$ & $\begin{array}{l}2.00 \\
1.95 \\
1.95 \\
1.67\end{array}$ & $\begin{array}{c}\text { O } \\
.34961 \text { E OO } \\
.34961 \text { E OO } \\
.62389 \text { E } 00 \\
2098.71 \\
0.0\end{array}$ & $\begin{array}{c}0 \\
.28023 \mathrm{E}-01 \\
.28023 \mathrm{E}-01 \\
.77734 \mathrm{E}-01 \\
5435.58 \\
0.0 \\
0\end{array}$ & $\begin{array}{c}0 \\
.25351 \mathrm{E}-01 \\
.25351 \mathrm{E}-01 \\
.55213 \mathrm{E}-01 \\
187.04 \\
0.0\end{array}$ & $\begin{array}{c}0 \\
.39830 \mathrm{E}-02 \\
.15794 \mathrm{E}-02 \\
.69615 \mathrm{E}-02 \\
14.55 \\
29478.02\end{array}$ & $\begin{array}{c}0 \\
.94925 \mathrm{E}-03 \\
.36741 \mathrm{E}-03 \\
.17551 \mathrm{E}-02 \\
512.17 \\
4.06\end{array}$ & $\begin{array}{c}0 \\
.48273 \mathrm{E}-02 \\
.19142 \mathrm{E}-02 \\
.86297 \mathrm{E}-02 \\
592.29 \\
632.96\end{array}$ & $\begin{array}{c}25.08 \\
0.0\end{array}$ \\
\hline 61 & 1 & $\begin{array}{c}0 \\
2.341 \\
0 \\
3.242\end{array}$ & $\begin{array}{l}901.71 \\
841.24 \\
888.46 \\
860.19\end{array}$ & $\begin{array}{l}2 \cdot 37 \\
2 \cdot 35 \\
2.35 \\
2.30\end{array}$ & $\begin{array}{c}0 \\
.27546 \text { E OO } \\
.27546 \text { E OO } \\
42700 \text { E OO } \\
4351.84 \\
0.0\end{array}$ & $\begin{array}{c}0 \\
.18401 \mathrm{E}-01 \\
.18401 \mathrm{E}-01 \\
.30850 \mathrm{E}-01 \\
3768.63 \\
0.0\end{array}$ & $\begin{array}{c}0 \\
.17626 \mathrm{E}-01 \\
.17626 \mathrm{E}-01 \\
.37926 \mathrm{E}-01 \\
96.55 \\
0.0\end{array}$ & $\begin{array}{c}0 \\
.25024 \mathrm{E}-02 \\
.15597 \mathrm{E}-02 \\
.37341 \mathrm{E}-02 \\
18.01 \\
17813.01\end{array}$ & $\begin{array}{c}0 \\
.50995 \mathrm{E}-03 \\
.31784 \mathrm{E}-03 \\
.12589 \mathrm{E}-02 \\
214.45 \\
1.81\end{array}$ & $\begin{array}{c}0 \\
.29456 \mathrm{E}-02 \\
.18360 \mathrm{E}-02 \\
.49285 \mathrm{E}-02 \\
462.81 \\
216.80\end{array}$ & $\begin{array}{c}29.27 \\
0.0\end{array}$ \\
\hline $6 i i$ & 2 & $\begin{array}{l}0 \\
2.324 \\
0 \\
3.259\end{array}$ & $\begin{array}{l}893.13 \\
837.18 \\
879.61 \\
853.03\end{array}$ & $\begin{array}{l}2 \cdot 37 \\
2 \cdot 35 \\
2 \cdot 35 \\
2 \cdot 30\end{array}$ & $\begin{array}{l}0 \\
.25756 \text { E } 00 \\
.25756 \text { E } 00 \\
40372 \text { E } 00 \\
4647.34 \\
0.0\end{array}$ & $\begin{array}{c}0 \\
.15130 \mathrm{E}-01 \\
.15130 \mathrm{E}-01 \\
.25325 \mathrm{E}-01 \\
3571.58 \\
0.0 \\
0\end{array}$ & $\begin{array}{c}0 \\
.14889 \mathrm{E}-01 \\
.14889 \mathrm{E}-01 \\
.32487 \mathrm{E}-01 \\
87.49 \\
0.0\end{array}$ & $\begin{array}{c}0 \\
.20265 \mathrm{E}-02 \\
.12716 \mathrm{E}-02 \\
.30379 \mathrm{E}-02 \\
15.16 \\
17850.32\end{array}$ & $\begin{array}{c}0 \\
.40006 \mathrm{E}-03 \\
.25105 \mathrm{E}-03 \\
.10184 \mathrm{E}-02 \\
179.36 \\
1.559\end{array}$ & $\begin{array}{c}0 \\
.23690 \mathrm{E}-02 \\
.14866 \mathrm{E}-02 \\
.40006 \mathrm{E}-02 \\
422.07 \\
176.02\end{array}$ & $\begin{array}{c}26.03 \\
0.0\end{array}$ \\
\hline $6 i i 1$ & 2 & $\begin{array}{c}0 \\
1.791 \\
0 \\
3.787\end{array}$ & $\begin{array}{l}913.36 \\
842.04 \\
946.27 \\
893.67\end{array}$ & $\begin{array}{l}2 \cdot 37 \\
2 \cdot 36 \\
2 \cdot 36 \\
2 \cdot 30\end{array}$ & $\begin{array}{c}0 \\
.27996 \text { E } 00 \\
.27996 \text { E } 00 \\
.52434 \text { E } 00 \\
2926.33 \\
0.0\end{array}$ & $\begin{array}{c}0 \\
.21854 \mathrm{E}-01 \\
.21854 \mathrm{E}-01 \\
67247 \mathrm{E}-01 \\
4598.63 \\
0.0 \\
0\end{array}$ & $\begin{array}{c}0 \\
.24818 \mathrm{E}-01 \\
.24818 \mathrm{E}-01 \\
.68663 \mathrm{E}-01 \\
149.43 \\
0.0\end{array}$ & $\begin{array}{c}0 \\
.35384 \mathrm{E}-02 \\
.16055 \mathrm{E}-02 \\
.84689 \mathrm{E}-02 \\
34.59 \\
17590.79\end{array}$ & $\begin{array}{c}0 \\
.10371 \mathrm{E}-02 \\
.47057 \mathrm{E}-03 \\
.28961 \mathrm{E}-02 \\
445.58 \\
3.19\end{array}$ & $\begin{array}{c}0 \\
.44682 \text { E-02 } \\
.20274 \text { E-02 } \\
.11251 \text { E-01 } \\
693.03 \\
495.10\end{array}$ & $\begin{array}{c}43.09 \\
0.0\end{array}$ \\
\hline $6 i v$ & 2 & $\begin{array}{l}0 \\
2.115 \\
0 \\
3.469\end{array}$ & $\begin{array}{l}906.46 \\
849.27 \\
926.79 \\
895.99\end{array}$ & $\begin{array}{l}2.37 \\
2.35 \\
2.35 \\
2.27\end{array}$ & $\begin{array}{c}0.0 \\
.26850 \mathrm{E} 00 \\
.26850 \mathrm{E} 00 \\
.47598 \mathrm{E} 00 \\
3817.06 \\
0.0\end{array}$ & $\begin{array}{c}0.0 \\
.19780 \mathrm{E}-01 \\
.19780 \mathrm{E}-01 \\
.47999 \mathrm{E}-01 \\
4183.37 \\
0.0\end{array}$ & $\begin{array}{c}0 \\
.15455 \mathrm{E}-01 \\
.15455 \mathrm{E}-01 \\
.33754 \mathrm{E}-01 \\
117.47 \\
0.0\end{array}$ & $\begin{array}{c}0 \\
.24281 \mathrm{E}-02 \\
.10758 \mathrm{E}-02 \\
.39293 \mathrm{E}-02 \\
26.55 \\
26827.94\end{array}$ & $\begin{array}{c}0 \\
.38626 \mathrm{E}-03 \\
.17114 \mathrm{E}-03 \\
.75934 \mathrm{E}-03 \\
323.35 \\
2.87\end{array}$ & $\begin{array}{c}0 \\
.27473 \mathrm{E}-02 \\
.12172 \mathrm{E}-02 \\
.46207 \mathrm{E}-02 \\
431.56 \\
305.94\end{array}$ & $\begin{array}{c}25.69 \\
0.0\end{array}$ \\
\hline $6 v$ & 1 & $\begin{array}{c}0 \\
1.740 \\
0 \\
3.841\end{array}$ & $\begin{array}{l}912.55 \\
846.25 \\
965.60 \\
915.89\end{array}$ & $\begin{array}{l}2.37 \\
2.35 \\
2.35 \\
2.28\end{array}$ & $\begin{array}{c}0.0 \\
.27198 \mathrm{E} 00 \\
.27198 \mathrm{E} 00 \\
.54934 \mathrm{E} 00 \\
2678.23 \\
0.0\end{array}$ & $\begin{array}{c}0 \\
.21331 \mathrm{E}-01 \\
.21331 \mathrm{E}-01 \\
84935 \mathrm{E}-01 \\
4804.44 \\
0.0\end{array}$ & $\begin{array}{c}0 \\
.20747 \mathrm{E}-01 \\
.20747 \mathrm{E}-01 \\
.55412 \mathrm{E}-01 \\
165.27 \\
0.0\end{array}$ & $\begin{array}{c}0 \\
.31221 \mathrm{E}-02 \\
.11487 \mathrm{E}-02 \\
.79988 \mathrm{E}-02 \\
40.59 \\
24093.73\end{array}$ & $\begin{array}{c}0 \\
.72563 \mathrm{E}-03 \\
.26697 \mathrm{E}-03 \\
.16590 \mathrm{E}-02 \\
557.90 \\
4.05\end{array}$ & $\begin{array}{c}0 \\
.37533 \mathrm{E}-02 \\
.13809 \mathrm{E}-02 \\
.95519 \mathrm{E}-02 \\
593.78 \\
573.71\end{array}$ & $\begin{array}{c}35.94 \\
0.0\end{array}$ \\
\hline
\end{tabular}




\begin{tabular}{|c|c|c|c|c|c|c|c|c|c|c|c|}
\hline $6 v i$ & 1 & $\begin{array}{c}0 \\
2.331 \\
0 \\
3.252\end{array}$ & $\begin{array}{l}905.84 \\
851.84 \\
911 \cdot 39 \\
886.35\end{array}$ & $\begin{array}{l}2.37 \\
2.34 \\
2.34 \\
2.27\end{array}$ & $\begin{array}{c}0 \\
.27179 \text { E } 00 \\
.27179 \text { E } 00 \\
.44534 \text { E } 00 \\
4200.24 \\
0.0 \\
0\end{array}$ & $\begin{array}{c}0 \\
.20446 \mathrm{E}-01 \\
.20446 \mathrm{E}-01 \\
.39507 \mathrm{E}-01 \\
3921.65 \\
0.0 \\
0\end{array}$ & $\begin{array}{c}0 \\
.14023 \mathrm{E}-01 \\
.14023 \mathrm{E}-01 \\
.28494 \mathrm{E}-01 \\
104.73 \\
0.0 \\
\end{array}$ & $\begin{array}{c}0 \\
.22972 \mathrm{E}-02 \\
.11721 \mathrm{E}-02 \\
.32268 \mathrm{E}-02 \\
22.25 \\
26775.22 \\
\end{array}$ & $\begin{array}{c}0 \\
.30379 \mathrm{E}-03 \\
.15495 \mathrm{E}-03 \\
.59697 \mathrm{E}-03 \\
269.13 \\
2.43 \\
\end{array}$ & $\begin{array}{c}0 \\
.25403 \mathrm{E}-02 \\
.12961 \mathrm{E}-02 \\
.37659 \mathrm{E}-02 \\
391.97 \\
248.06\end{array}$ & $\begin{array}{c}22.79 \\
0.0 \\
\end{array}$ \\
\hline $6 v i$ & 3 & $\begin{array}{c}0 \\
2.031 \\
0 \\
3.552\end{array}$ & $\begin{array}{l}901.14 \\
849.87 \\
913.69 \\
885.22\end{array}$ & $\begin{array}{l}2.37 \\
2.35 \\
2.35 \\
2.27\end{array}$ & $\begin{array}{c}0 \\
.24974 \text { E } 00 \\
.24974 \text { E O0 } \\
.44668 \text { E } 00 \\
4192.60 \\
0.0 \\
0\end{array}$ & $\begin{array}{c}0 \\
.17580 \mathrm{E}-01 \\
.17580 \mathrm{E}-01 \\
39344 \mathrm{E}-01 \\
3935.28 \\
0.0\end{array}$ & $\begin{array}{c}0 \\
.12288 \mathrm{E}-01 \\
.12288 \mathrm{E}-01 \\
.28198 \mathrm{E}-01 \\
104.89 \\
0.0\end{array}$ & $\begin{array}{l}0 \\
.19890 \mathrm{E}-02 \\
.95218 \mathrm{E}-03 \\
.32428 \mathrm{E}-02 \\
22.18 \\
26527.02 \\
\end{array}$ & $\begin{array}{c}0 \\
.26100 \mathrm{E}-03 \\
.12494 \mathrm{E}-03 \\
.59652 \mathrm{E}-03 \\
268.39 \\
2.40\end{array}$ & $\begin{array}{cc}0 \\
.21910 \mathrm{E}-02 \\
.10489 \mathrm{E}-02 \\
.37817 \mathrm{E}-02 \\
389.95 \\
247.16\end{array}$ & $\begin{array}{c}22.56 \\
0.0\end{array}$ \\
\hline $\begin{array}{l}\text { Standard } \\
\text { April } \\
\text { Case }\end{array}$ & & $\stackrel{0}{5.5833}$ & $\begin{array}{l}922.59 \\
850.76\end{array}$ & $\begin{array}{l}2.37 \\
2.29\end{array}$ & $\begin{array}{c}0 \\
40397 \text { E } 00 \\
4550.58 \\
0.0\end{array}$ & $\begin{array}{c}0 \\
37634 \text { E-01 } \\
3573.64 \\
0.0\end{array}$ & $\begin{array}{c}0 \\
.31145 \text { E-01 } \\
96.41 \\
0.0\end{array}$ & $\begin{array}{c}0 \\
.46211 \quad \mathrm{E}-02 \\
21.01 \\
17802.21\end{array}$ & $\begin{array}{c}0 \\
.90337 \text { E-03 } \\
257.53 \\
1.70\end{array}$ & $\begin{array}{c}0 \\
.54637 \text { E-02 } \\
412.02 \\
240.46\end{array}$ & $\begin{array}{c}26.13 \\
0.0\end{array}$ \\
\hline
\end{tabular}




\section{APPEIDIX 14}

\section{PRLOR IN $\mathrm{C}_{\mathrm{p}}$ OF BENZENE}

The value of (a) for benzene should have been - 409 . This error was made in all programmes run but it is almost unnoticeable. The fipril case was run with this correction and the results below may be compared to the fpril case in Appendix 13.

\begin{tabular}{l|c|c} 
& INITIAI & EINAL \\
\hline Bed Depth (Ft.) & 0 & 5.5833 \\
Temperature ( ${ }^{\mathrm{K}}$ ) & 922.59 & 850.79 \\
Pressure (Atmosphere) & 2.37 & 2.29 \\
$\mathrm{X}_{1}$ & 0 & $.40411 \mathrm{E} 00$ \\
$\mathrm{X}_{2}$ & 0 & $.37643 \mathrm{E}-01$ \\
$\mathrm{X}_{3}$ & 0 & $.31153 \mathrm{E}-01$ \\
$\mathrm{X}_{1+}$ & 0 & $.46222 \mathrm{E}-02$ \\
$\mathrm{X}_{15}$ & 0 & $.90368 \mathrm{E}-03$ \\
$\mathrm{X}_{16}$ & 0 & $.54652 \mathrm{E}-02$
\end{tabular}

\section{PRODUUCT_DISTCRIBUTION}

\begin{tabular}{|c|c|c|c|}
\hline COHPOUND & $\begin{array}{l}\text { A.PT. IN PRODUCT } \\
\mathrm{LB} / \mathrm{HR} \text {. }\end{array}$ & COMPOUITD & $\begin{array}{l}\text { ART. IN PRODUC'I } \\
\text { LB/HR. }\end{array}$ \\
\hline Ethylbenzene & 4550.03 & Ethane & 0.0 \\
\hline Styrene & 3574.04 & Acetylene & 0.0 \\
\hline liydrogen & 96.42 & Pthynylbenzene & 0.0 \\
\hline Ethylene & 21.02 & Steam & 17302.16 \\
\hline Benzene: & 257.58 & Carbon rionoxide & 1.70 \\
\hline Toluene & 412.03 & Carbon Dioxide & 240.52 \\
\hline Methane & 26.13 & Carbon & 0.0 \\
\hline
\end{tabular}

It is concluded that there is no need for worry. 


\section{APPENDIX_15}

\section{VALIDITY OF dP/CZ TREATIEATT}

The pressure drop of the reactor had been found by the following "wrong" equation ( Equation 1):

$$
\frac{\mathrm{dP}}{\mathrm{dz}}=\frac{\mathrm{v}_{\mathrm{o}}(1-\epsilon)}{\mathrm{D}_{\mathrm{p}} \epsilon^{3}} \cdot\left(\frac{150 y(1-\epsilon)}{\mathrm{D}_{\mathrm{p}}}+1.75 \rho_{\mathrm{g}}\right) \cdot \frac{1}{144 \times \mathrm{gc} \times 14.7}
$$

where a choice of $E=0.35$ gave the reported plant pressure drop of about $1 \mathrm{psi}$. This equation is linear with respect to $\mathrm{V}_{0}$

The correct Ergun Equation, not used in any of the runs, is (Equation 2)

$$
\frac{d P}{d Z}=\frac{v_{0}(I-\epsilon)}{D_{p} \epsilon^{3}} \cdot\left(\frac{150 \mu(1-\epsilon)}{D_{p}}+1.75 v_{0} P_{g}\right) \cdot \frac{1}{144 \times g c \times 14.7} \mathrm{ft.}
$$

The second term on the right hand side accounts for pressure drop due to turbulent flow, i. e. $v_{0}^{2}$. By choosing an appropriate $\epsilon(\epsilon=0.445)$ for Equation 2 it was possible to establish a pressure profile alnost as that given by Equation 1. Both values are reasonable choices for the catalyst bed in question and over the range of $v_{0}$ values met (about $2.0 \mathrm{ft.} / \mathrm{sec}$. to 7.0 ft./sec.), the equations are equivalent. Hand calculations of 
pressure drop for the existing bed (length $=5.5833 \mathrm{ft.}$ ) and several comparisons of programmes run with each equation are offered as proof.

\section{(i) Hand Calculations}

\begin{tabular}{|c|c|c|c|c|}
\hline $\begin{array}{l}\mathrm{dP} / \mathrm{dZ} \text { BY } \\
\text { EQUATION } \\
\text { NUIBTR }\end{array}$ & $\begin{array}{l}\text { B品D } \\
\text { VOID- } \\
\text { AGE } \\
\quad E\end{array}$ & $\begin{array}{c}V_{0} \\
\text { FT./3EC. }\end{array}$ & $\begin{array}{l}\text { APPROX.* aP } \\
\text { FOR } 5.5833 \text { FT. } \\
\text { (ATMOS.) }\end{array}$ & $\begin{array}{r}\mathrm{dP} \\
\text { psi }\end{array}$ \\
\hline 1 & 0.35 & 2.0 & 0.0335 & .492 \\
\hline 1 & 0.35 & 7.0 & 0.117 & 1.72 \\
\hline 2 & 0.445 & 2.0 & 0.018 & .264 \\
\hline 2 & 0.445 & 7.0 & 0.156 & 2.29 \\
\hline
\end{tabular}

* For the calculations leading to these results the following terms were considered to be constent throughout :

$$
\begin{aligned}
& \rho_{g}=0.045 \mathrm{Lb} . / \mathrm{Ft}^{3} \\
& D_{p}=0.0153 \mathrm{Ft} . \\
& \mu=0.03 \times 6.72 \times 10^{-4} \mathrm{Lb} . / \mathrm{Ft} . \mathrm{Sec} .
\end{aligned}
$$

Since the reactor normally runs around 4 to $5 \mathrm{ft.} / \mathrm{sec}$. (superficial velocity), equations 1 and 2 give almost the same pressure drops. 


\section{(ii) Various Cases Run ilith Both dP/dz Equations}

\section{(1) April Case}

\begin{tabular}{|c|c|c|c|c|}
\hline $\begin{array}{l}\text { dP/AZ BY } \\
\text { EQUATIONT }\end{array}$ & 1 & 2 & 2 & 2. \\
\hline$\epsilon$ & 0.35 & 0.35 & 0.44 & 0.45 \\
\hline Inlet pressure (Atnos.) & 2.37 & $2 \cdot 37$ & 2.37 & 2.37 \\
\hline Outlet pressure (Atmos.) & 2.287 & 2.156 & 2.282 & 2.290 \\
\hline Inlet teinperature $\left({ }^{O_{K}}\right)$ & 922.59 & 922.59 & 922.59 & 922.59 \\
\hline Outlet temperature $\left({ }^{O_{K}}\right)$ & 850.76 & 851.12 & 850.78 & 850.76 \\
\hline \multicolumn{5}{|l|}{$\begin{array}{l}\text { PRODUCT } \\
\text { FLON RETES (LS./HR.) }\end{array}$} \\
\hline Ethylbenzene & 4550.58 & 4578.78 & 4551.51 & 4549.93 \\
\hline Styrene & 3573.64 & 3563.01 & $3573 \cdot 32$ & 3573.86 \\
\hline Hyarogen & 96.41 & $95 \cdot 31$ & 96.37 & 96.43 \\
\hline Ethylene & 21.01 & 21.96 & 21.04 & 20.99 \\
\hline Benzene & $257 \cdot 53$ & 255.68 & 257.47 & $257 \cdot 57$ \\
\hline Toluene & 412.02 & 399.13 & 411.57 & $412 \cdot 34$ \\
\hline Methane & 26.02 & 24.81 & 26.08 & 26.16 \\
\hline Ethane & 0.0 & 0.0 & 0.0 & 0.0 \\
\hline Acetylene & 0.0 & 0.0 & 0.0 & 0.0 \\
\hline Sthynylbenzene & 0.0 & 0.0 & 0.0 & 0.0 \\
\hline Stean & 17802.21 & 17808.54 & 17802.43 & 17802.06 \\
\hline Carbon Monoxice & 1.70 & 1.87 & 1.71 & 1.70 \\
\hline Carbon Dioxicie & 240.46 & 232.59 & 240.19 & 240.65 \\
\hline Carbon & 0.0 & 0.0 & 0.0 & 0.0 \\
\hline
\end{tabular}


(2) Situation 6v (defined in section 8.1.2)

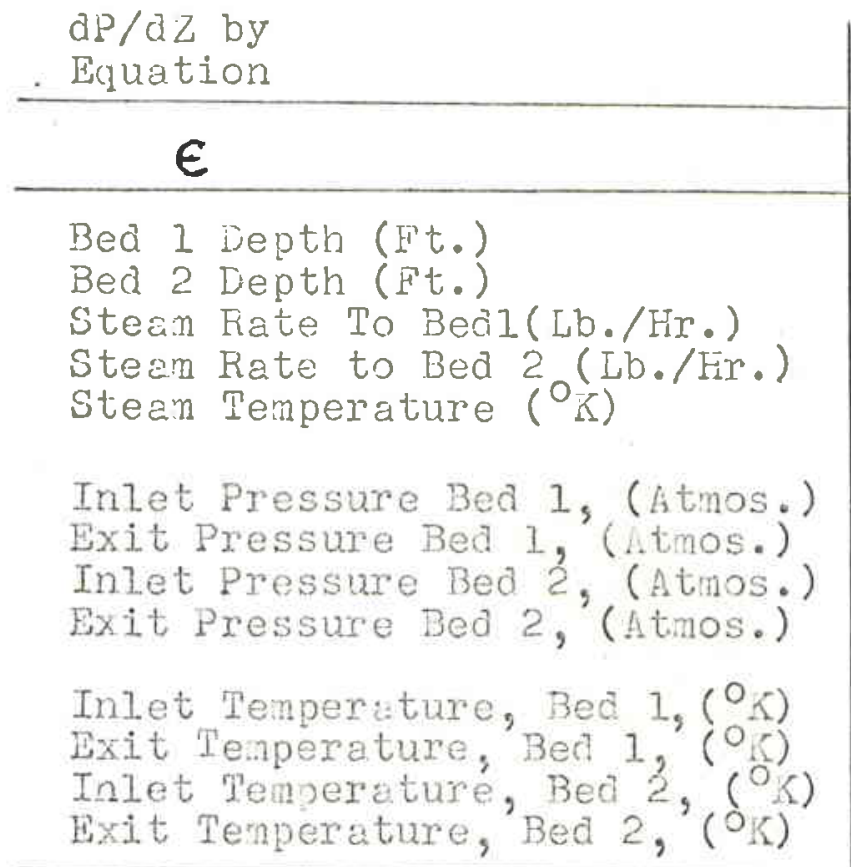

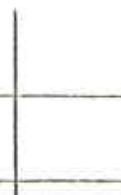

122

$\begin{array}{lll}0.35 & 0.35 & 0.445\end{array}$

9038

15528

3.841

1124.72

2.37
2.35
2.35
2.28

912.55

846.25

965.60

915.89
9033

3.841

15528

1124.72

2.37
2.34
2.34
2.09

912.55

845.29

965.62

916.60
1.74

3.841

9038

15528

1124.72

2.37

2.36

2.36

2.26

912.55

846.22

965.58

915.92

PRODUST FLOA RATIS (LB./HE.)

Ethylbenzene

Styrene

Hydrozen

Ethylene

Benzene

Toluene

jie thane

Ethane

Acetylene

Ethynylbenzene

Steara

Carbon Monoxide

Carbon Dioxide

Carbon

GAIN (

$2678.23 \quad 2727.58 \quad 2680.32$

$\begin{array}{lll}4804.44 & 4786.33 \quad 4803.77\end{array}$

$165.27 \quad 162.07 \quad 165.11$

$\begin{array}{lll}40.59 & 43.73 & 40.74\end{array}$

$557.90 \quad 551.80 \quad 557.43$

$593.78 \quad 574.17 \quad 593.11$

$35.94 \quad 34.37 \quad 35.86$

$\begin{array}{lll}0.0 & 0.0 & 0.0\end{array}$

$\begin{array}{lll}0.0 & 0.0 & 0.0\end{array}$

$\begin{array}{lll}0.0 & 0.0 & 0.0\end{array}$

$24093.73 \quad 24112.38 \quad 24095.06$

$\begin{array}{lll}4.05 & 4.75 & 4.10\end{array}$

$573.71 \quad 550.82 \quad 572.51$

$\begin{array}{lll}0.0 & 0.0 & 0.0\end{array}$

$144.53 \quad 144.92 \quad 144.55$ 
(3) Extreme Extrapolation of Model-(Single bed) Like April Case with Bed Deoth $=10$ Ft., Steam Rate $=30000 \mathrm{Lb} . / \mathrm{Hr}$.

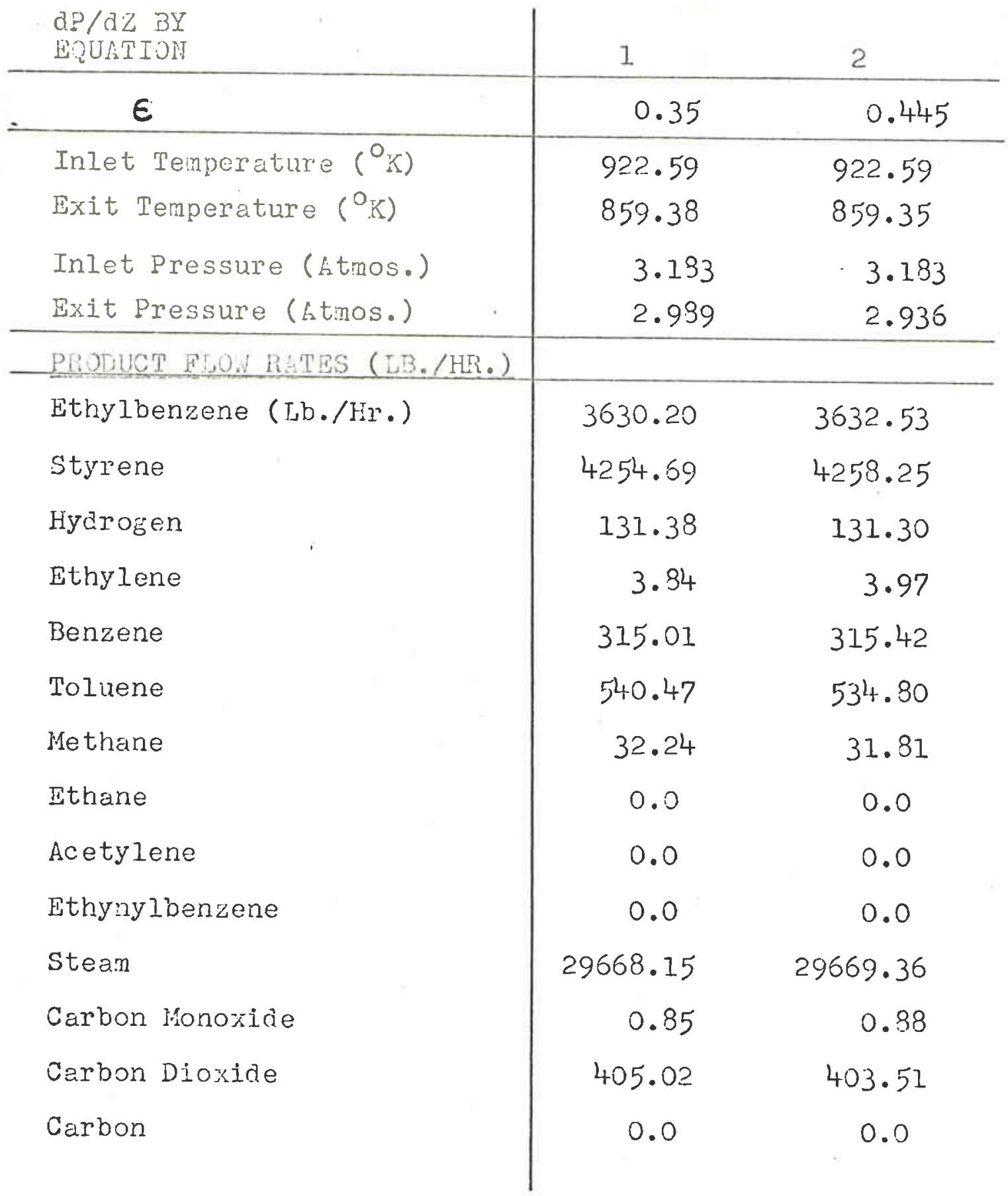

